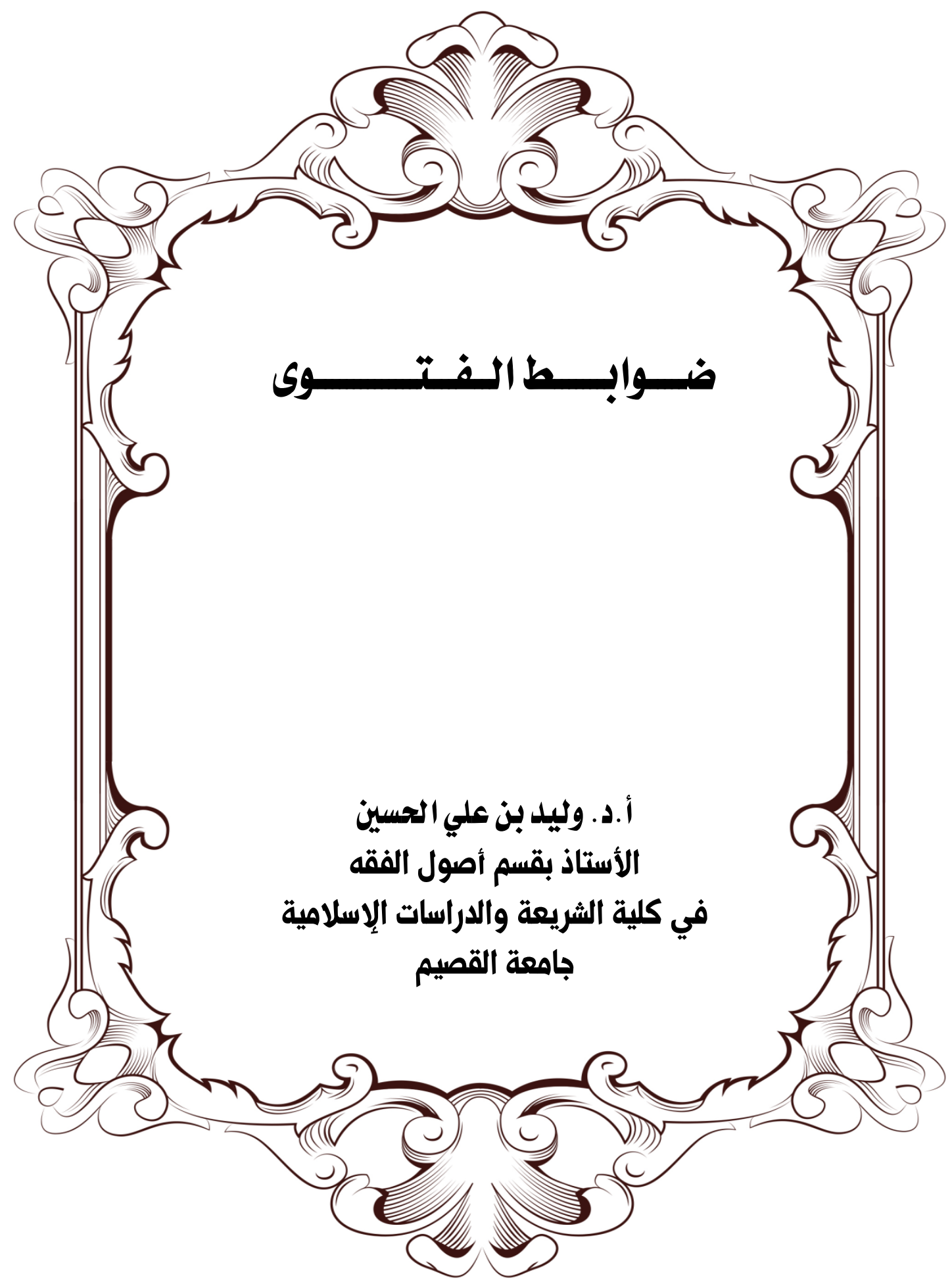


مجلة كلية الدراسات الإسلامية والعربية للبنات بدمنهور العدد السادس الإصدار الثاني الجزء الأول اب.rم

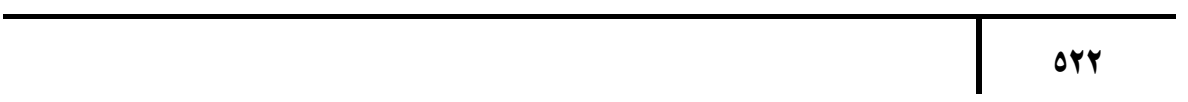




\section{ضوابط الفتوى}

وليد بن علي الحسين

قسم أصول الفقه في كلية الثريعة وإلاراسات الإسلامية جامعة القصيم البريد الإكتروني : whsien@qu.edu.sa

الملخص:

يتتاول هذا البحث بيان ضوابط الفتوى التي يجب على المفتي مراعاتها عند

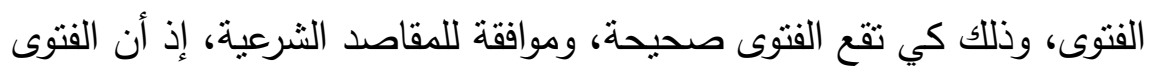
تعتمد على معرفة الحكم الثرعي، وحسن تنزيله على الواقع والمكلفين، وهذه الضوابط هي: أن تصدر الفتوى من مفتٍ مؤهل للفتيـا، وأن يتصـور المفتي المسـألة، وأن تكون الفتوى مبنية على أصلٍٍ شرعي معتبر ، وأن مؤل تكون الفتوى مراعية لحال المستفتي، وأن تكون الفتوى مبنية على مراعاة الواقع، وأن تكون الفتوى موافقة لمقاصد الثريعة.

وقد بينت المراد بهذه الضوابط، وتأصيلها، وما يترتب على عدم تحقيقها، أسأل

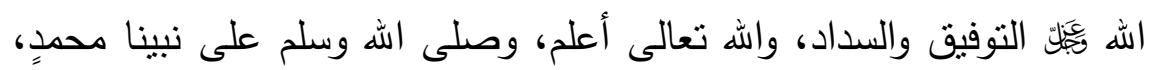
وعلى آله وصحبه وسلم.

الكلمات الافتتاحية: ضوابط الفتوى- الفتوى - ضوابط - حال المستفتي -

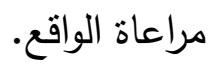


مجلة كلية الدراسات الإسلامية والعربية للبنات بدمنهور العدد السادس الإصدار الثاني الجزء الأول آب.rم

\section{Fatwa controls}

\section{Walid bin Ali Al Hussein}

The Department of Fundamentals of Jurisprudence at the College of Sharia and Islamic Studies, Qassim University

\section{E-mail: whsien@qu.edu.sa}

\section{Abstract:}

This research deals with a statement of the fatwa controls that the mufti must observe when issuing a fatwa, in order for the fatwa to be valid and in agreement with the legitimate purposes, as the fatwa depends on the knowledge of the legal ruling, and its good application to reality and those charged with it, and these controls are: The fatwa is issued by a qualified fatwa And that the matter should be conceived by the Mufti, and that the fatwa should be based on a sound Shariah origin, and that the fatwa should be based on the legality of the fatwa, and that it is in accordance with the fatwa.

I have clarified what is meant by these controls, their rooting, and the consequences of not achieving them.

Keywords: Fatwa Controls - Fatwa - Controls - The

Questioner's Condition - Taking Into Account Reality. 
بسم الله الرحمن الرحيم

\section{مقـدمــة:}

إنَّ الحمد الله نحمده، ونستعينه، ونستغفره، ونعوذ بالله من شرور أنفسنا،

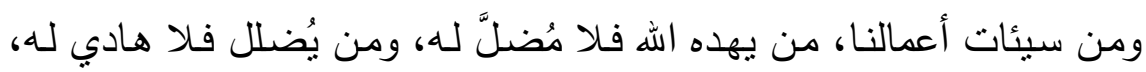

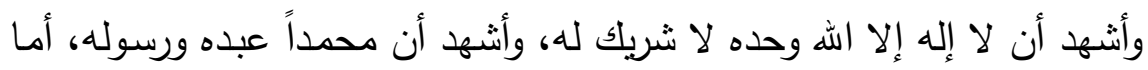

فإن الفتوى منصبُ جليل القدر، عظيم الثـأن، فهي من أهم المناصب، وأعلاها قدراً، وأكثرها أثثراً، وأعظمها خطراً، فبها تعرف أحكام الثريعة، مها

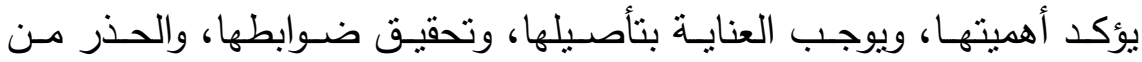
مزالقها، وقد اعتتى الأصوليون ببيان أحكامها، وأنواعها، وآدابها، وشروطها، وآثنارها، ومجالها، وما يتعلق بها من مسائل، كما زخرت كتبهم بالفتاوى، وبيان الحكم الثرعي في النوازل والمستجدات التي استجدت في عصورهم، ولما كانت الفتوى قائمةً على معرفة الحكم الثرعي، وحسن تنزيله على الواقع والمكلفين،

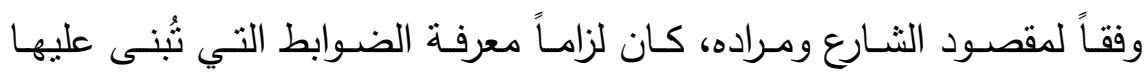

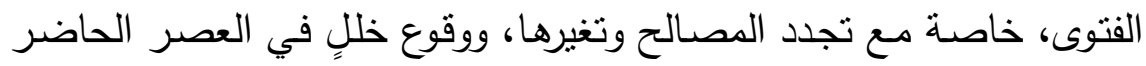

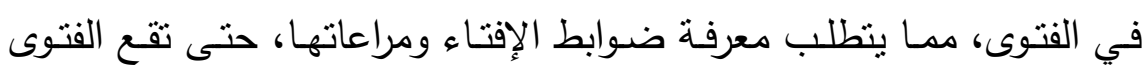

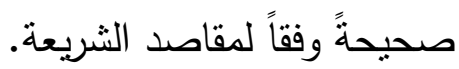
وقد دعاني لبحث هذا الموضوع أسبابُ عدة، كان من أبرزها ما يأني:

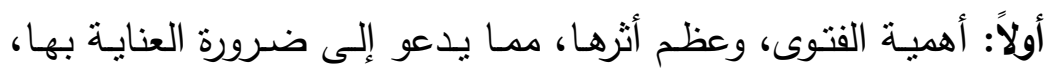

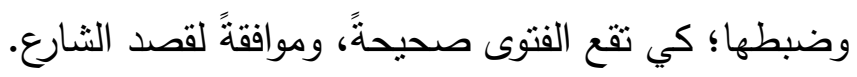
ثانياً: حاجة المفتي إلى معرفة الضوابط التي يجب عليه عليه مراعاتها عند الإفتاء، والتأكد من تحققها قبل صدور الفتوى. ثالثاً: أثز الفتاوى غير المنضبطة لتخف إحدى ضوابطها، وما يترتب على عدم صحتها من آثارٍ سيئة، ومفاسد عظيمة. 
رابعاً: نساهل بعض المفتين اليوم في الجرأة على الفنبا بلا علم، وكثرة

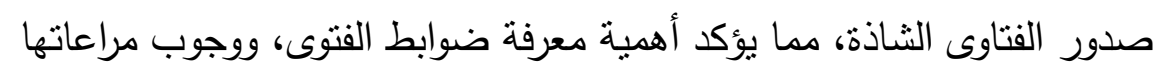
عند الإفتاء.

ويهدف هذا البحث إلى بيان المراد بضوابط الفتيا، ومعرفة الضوابط

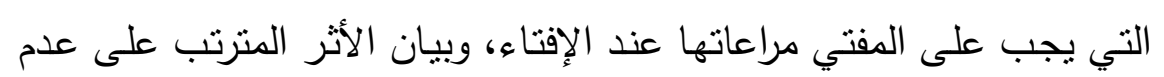
مراعاة ضوابط الفتوى.

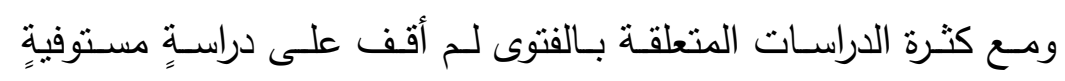

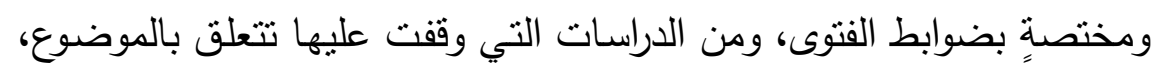

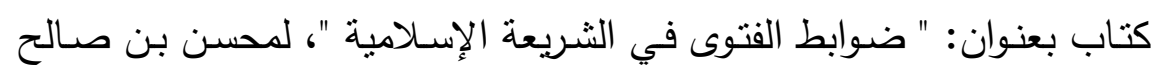

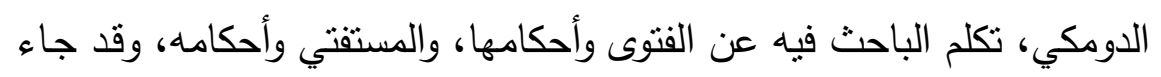

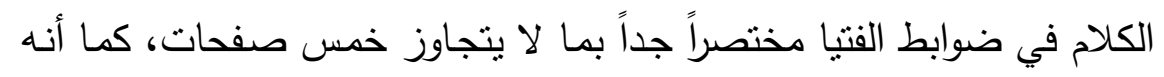

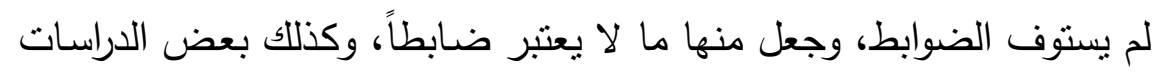

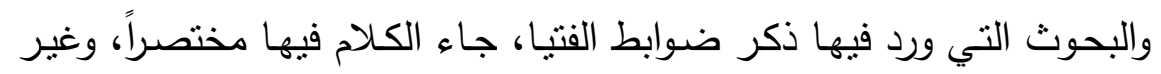

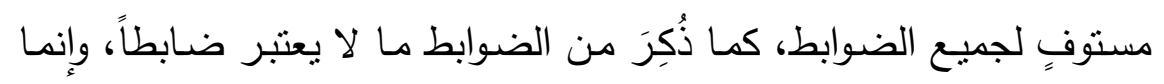

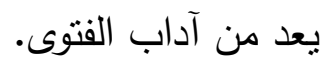


وقد جعلت خطـة البحث في تمهيد، وستة مباحث، وخاتمـة، وفهرس

للمصادر والمراجع، كالتالي: - الم:

$$
\text { التمهيد: في التعريف بمفردات البحث. }
$$

المبحث الأول: أن تصدر الفتوى من مفتٍ مؤهل للفتيـا. المبحث الثاني: أن يتصسور المفتي المسـألة.

المبحث الثالث: أن تكون الفتوى مبنيةً على أصلٍ شرعي معتبر . المبحث الرابع: أن تكون الفتوى مراعيةً لحال المستفتي. المبحث الخامس: أن تكون الفتوى مبنيةً على مراعاة الواقع. المبحث السادس: أن نكون الفتوى موافقةً لمقاصد الشريعة.

الخاتمة.

فهرس المصادر وإلمراجع.

أسأل اله لَّئلَ أن يوفقني فيه للسداد والصواب، وأن يغفر لي ما كان فيه

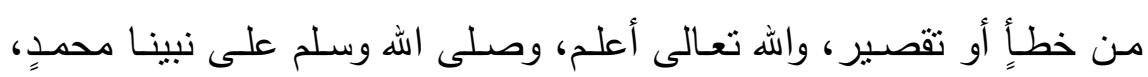
وعلى آله وصحبه وسلم. 
التمهيد: في التعريف بمفردات البحث:

يتكون عنوان البحث من كلمنين: الضوابط، والفتوى، وبيانها كالتالي: الضوابط: جمع ضابط، وهو مأخوذ ضبط الثيء يضبطه ضبطاً، أي حفظاً بليغاً، والضبط في اللغة يطلق على لزوم الثـيء وحبسـه (') وذكر ابن

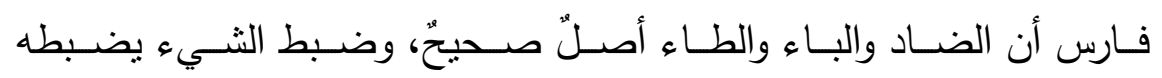
ضبطاً (') أي حفظه بالحزم، فالمعاني اللغوية تدل على الحفظ، والحزم، والقوة، والاتقان، وملازمة الثيء، وإحكام الثيء وإتقانه، والمراد به هنا معناه اللغوي. وأما معنى الفتوى في اللغة: فهي اسم مصدرٍ للفعل (فتى)، يُقال: فتى يُفتي فتيا، وبطلق الإفتاء في اللغة على معنبين: الأول: الطراوة والجِدَّة: ومنه الفتى، وهو الثاب الحدث الذي شبَّ وقوي،

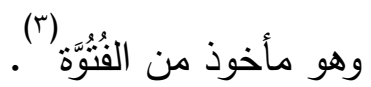
الثاني: الإبانة: ومنه الفُتيا، بمعنى تبيين الحكم، يقال: أفتاه في الأمر،

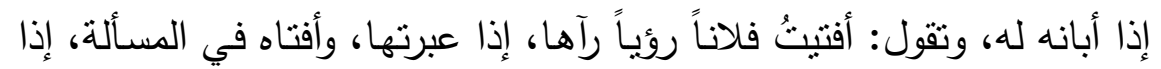

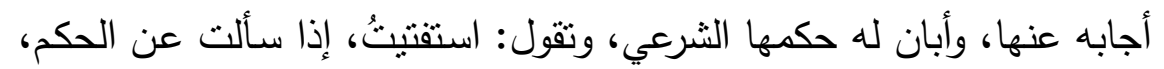

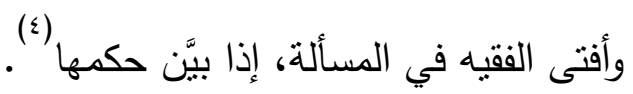
ويتبين بهذا أن المعنى الاصطلاحي مـأخوذّ مـن المعنى الثاني، وهو

وأما في الاصطلاح فقد ورد في تعربف الفتوى اصطلاحاً عدة تعريفات،

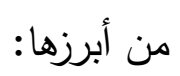

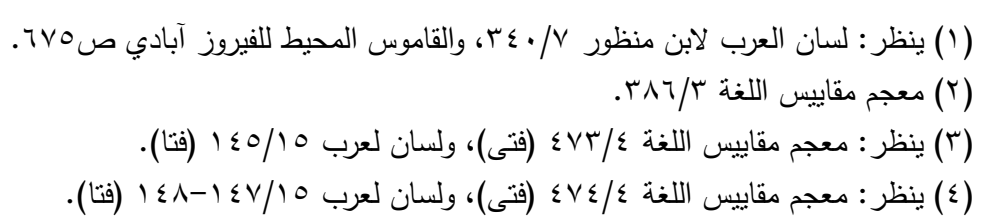




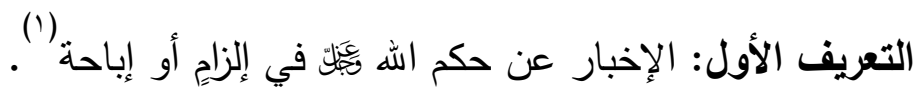

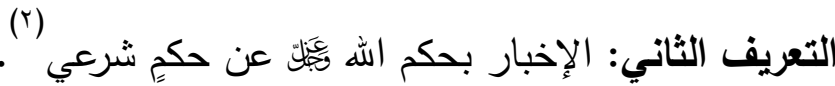

التعريف الثالث: تنيين الحكم الثرعي عن دليلٍ لمن سأل عنه '".

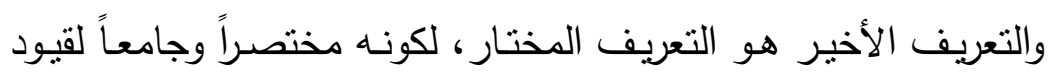

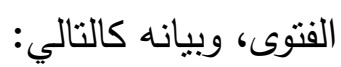

(تبيين): هذا جنسُ في التعريف يبين حقيقة الفتوى، وأنها بيان للحكم وإخبار به من غير إلزام، ويخرج بهذا القضاء.

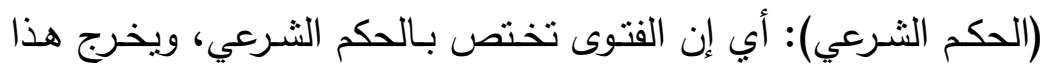
الأحكام غير الثرعية. (عن دليل): أي أن الفتوى تكون مبنية على دليل، وهذا يخرج الفتوى بغير دليل، كمن ينقل فتوى غيره، فلا يسمى فتوى.

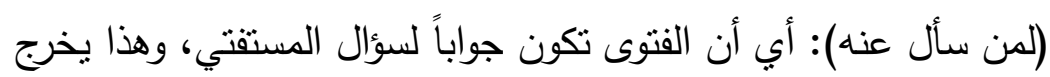
بيان الحكم ابتداءً بغير سؤال فلا يسمى فنتيا، وإنما يُسمى إرشاداً وتعليماً.

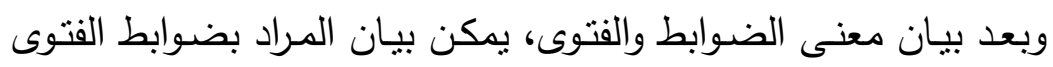

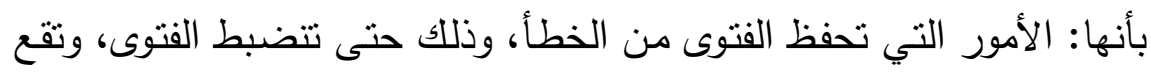

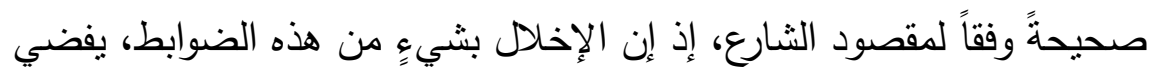
إلى خطأ الفتوى، وعدم صحتها. 


\section{المبحث الأول:}

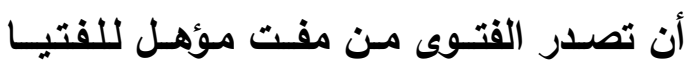

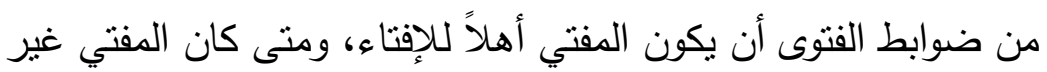

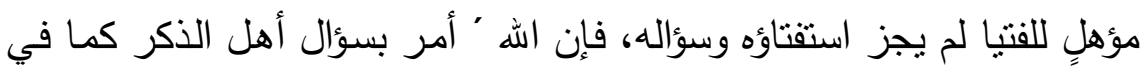

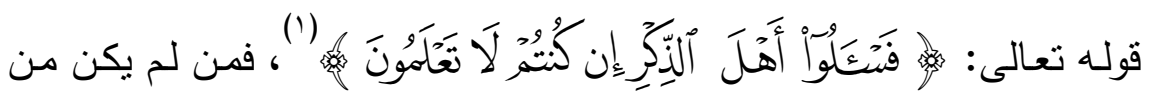
أهل الذكر لا يجوز له الإفتاء، ولا استفتاؤه، وإذا كان المستفتي يعلم بعدم أهلية

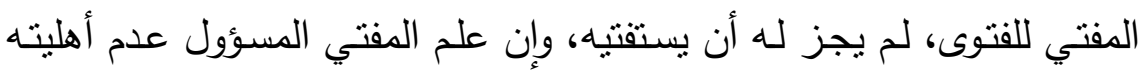

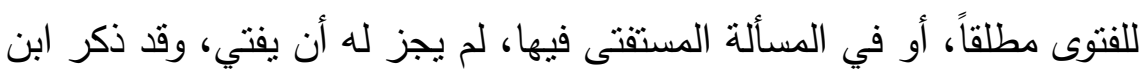

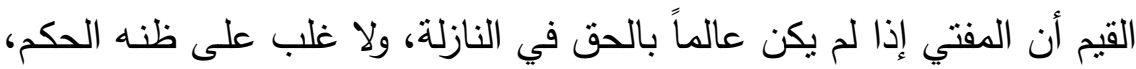

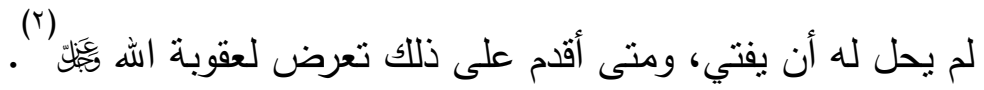

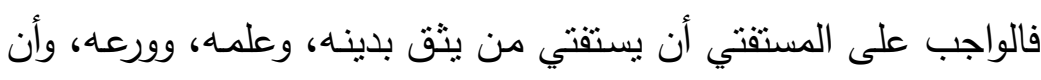

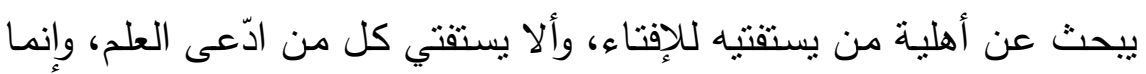

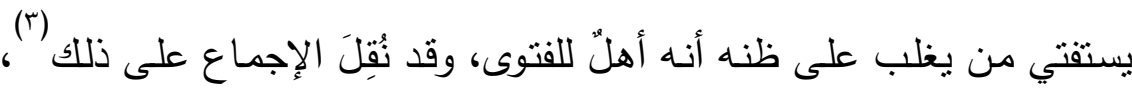
يقول الباجي:" ويجب على العامي أن بسأل عمن بريد أن بستفتيه، فإذا أُخبرَ

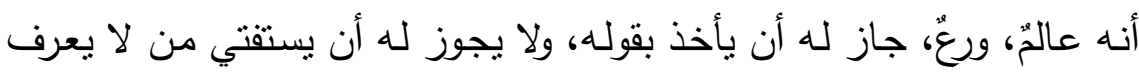

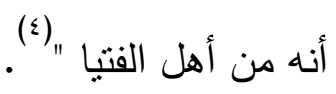

$$
\begin{aligned}
& \text { (1) من سورة النحل رقم (T؟). }
\end{aligned}
$$

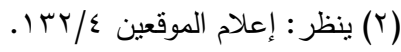

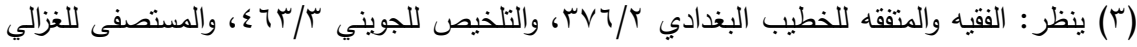

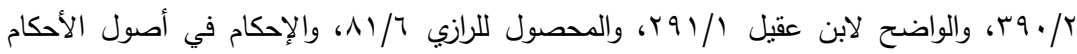

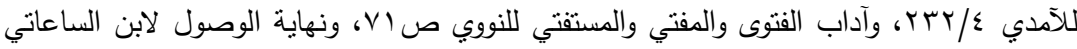

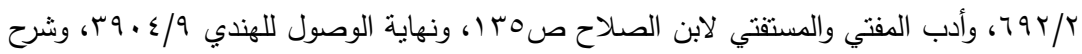

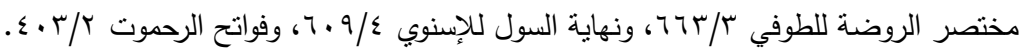


ويقـول الثـاطبي: " إن السـائل لا يصـح أن يسـأل مـن لا يُعتبـر فـي

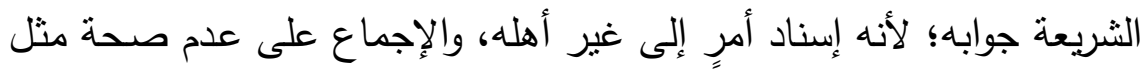

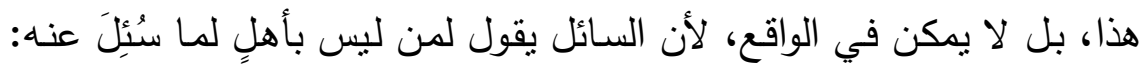

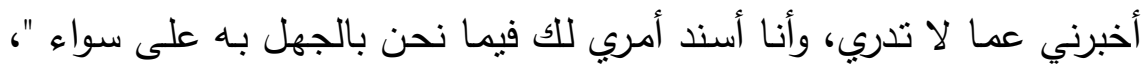

$$
\text { ثم قال: " والإطناب في هذا غير محتاجِ إليه "( (1). }
$$

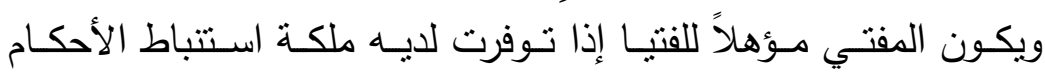

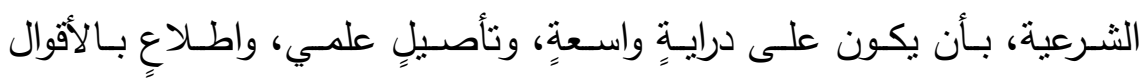

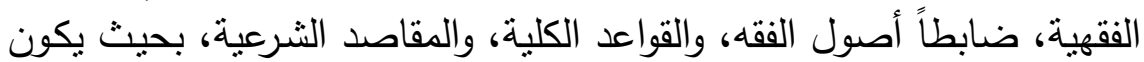
متمكناً من استتباط الحكم الشرعي من دليله، وذلك إنما يتحقق عندما تتوفر ولهر

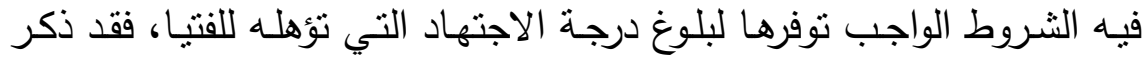

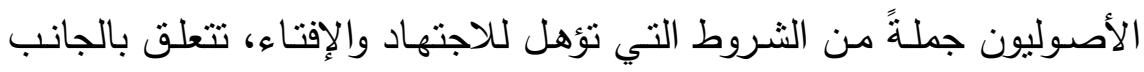
العلمي، والمعرفي، والملكة، حيث اثتنرطوا في المجتهد أن يكون عارفاً بعددٍ

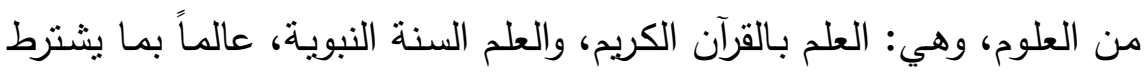

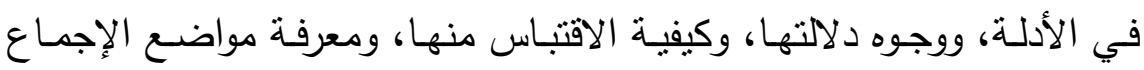

والخلاف، ومعرفة أصول الفقه، ومعرفة اللغة العربية ودلالاتها (؟).

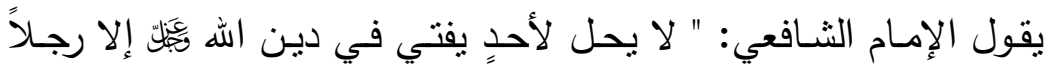

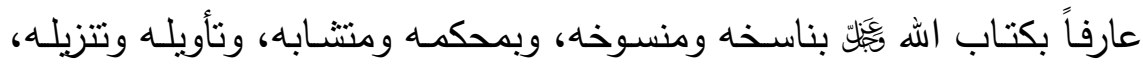

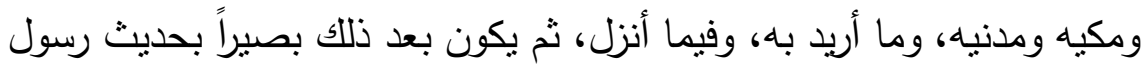

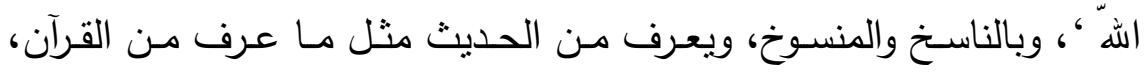

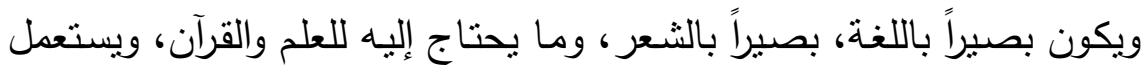

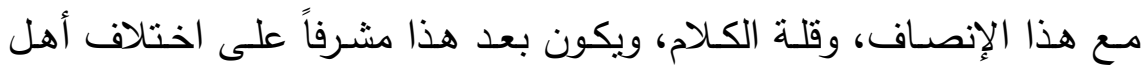

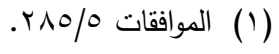

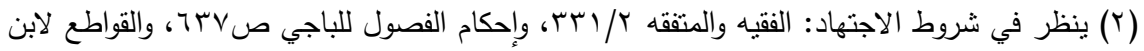

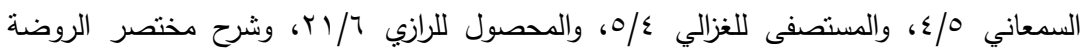

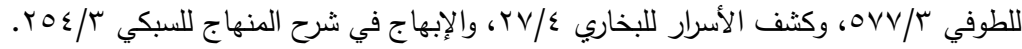


الأمصار ، ويكون له قريحة بعد هذا، فإذا كان هذا هكذا، فله أن يتكلم ويفتي

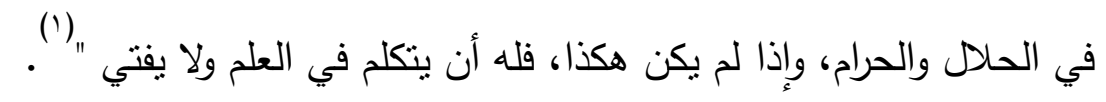

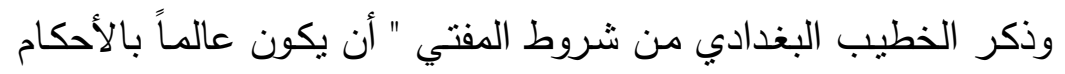

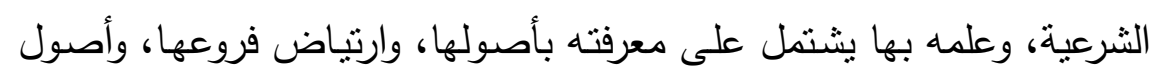

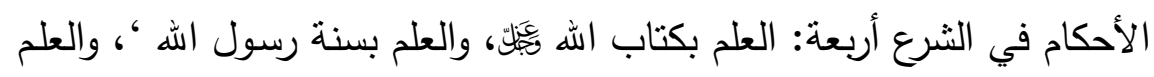

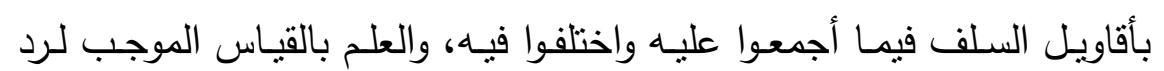

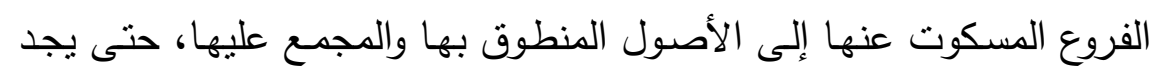

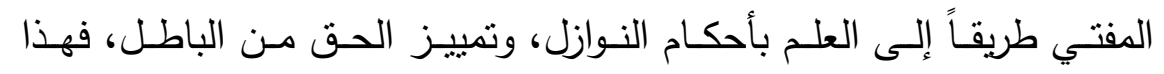
لا مندوحة للمفتي عنه، ولا يجوز لله الإخلال بشيءٍ منه "(r).

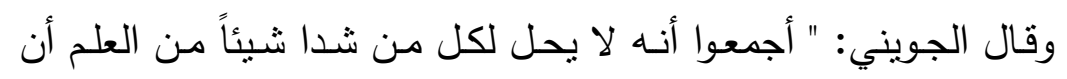

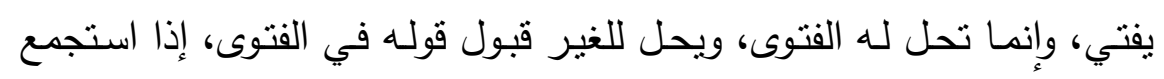

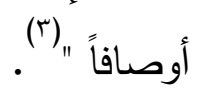

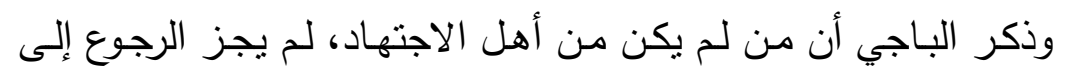

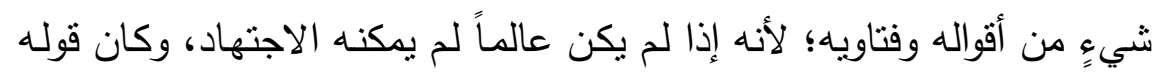
تخميناً، وذللك غير جائز ، وكان بمنزلة العوام (؛ُ . وذكر ابن السـمعاني أن المفتي مـن العلمـاء مـن استكملت فيـه ثناتثة

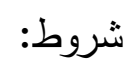
الأول: أن يكون من أهل الاجتهاد. الثاني: أن يستكمل أوصاف العدالة في الدين، حتى يثق بنفسه في التزام حقوقه، ويوثق به في القيام بشروطه. 
الثالث: أن يكون ضـابطاً لنفسـه من النسـيل، كافاً لها عن الترخيص

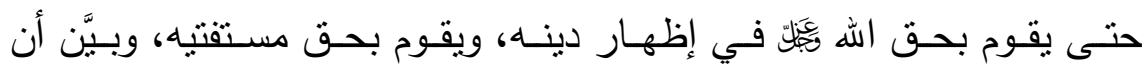

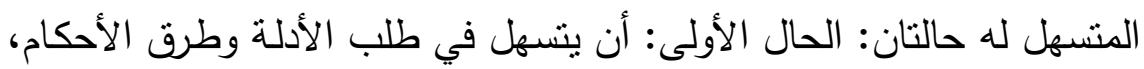

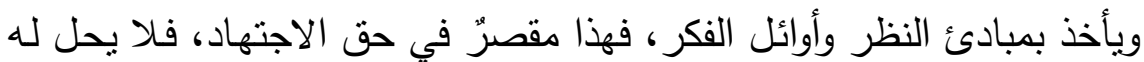

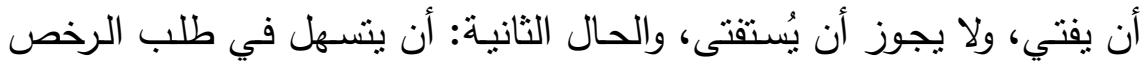
وتأول الثبه، ويمعن في النظر إلبها ليتوصل إلبها، ويتعلق بأضعفها، فهذا

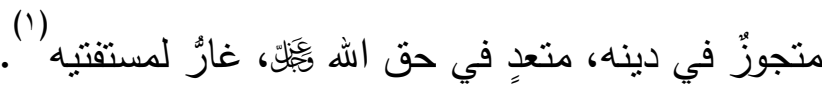

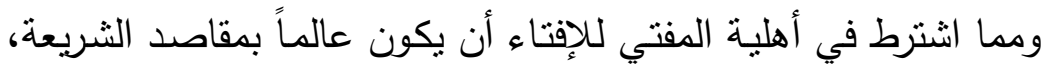
مدركاً للحكم والمصالح التي راعاها الثـارع في نتريعه؛ كي يتمكن من فهم النصوص والأحكام الثـرعية في ضوء مقاصدها، دون الوقوف على ظواهر النصوص وألفاظها، وليكون محيطاً بأحكام الثريعة، عارفاً بكلياتها، متمكناً من لن الأن رد الفروع إلى أصولها وقواعدها، إذ أن فهم النصوص الثرعية وتطبيقها على بلى الثرئه

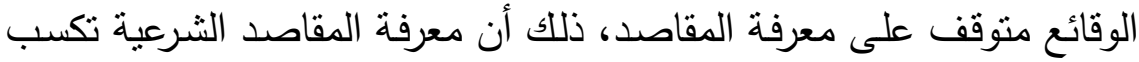
(r) المفتي معرفة النصوص الشرعية، وفهمها على معناها الصحيح ، وتمكنه من تطبيقها وإعمالها على الوقائع والمستجدات، وعدم الاضطراب في الفتيا، مما يجعل الفتوى أقرب إلى الحق والصواب، وهي تقيد المفتي في معرفة حكم كل

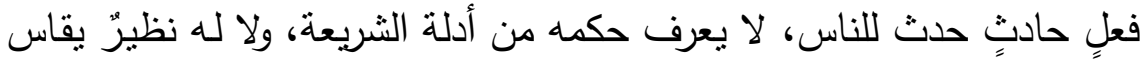

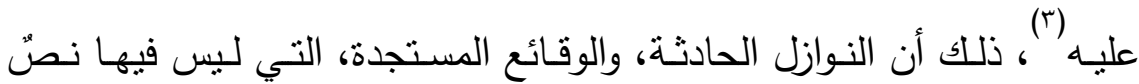
شرعي، تتدرج تحت كليات الثرع، وقواعده الكلية، ومقاصد الثريعة، فيستمد

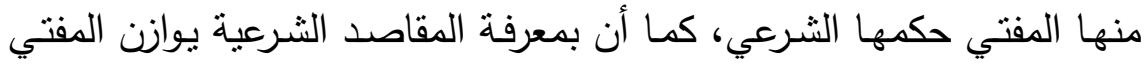


بين الجزئيات والكليات، حتى تقع الفتوى محققةً للكليات، ولا يؤخذ الجزئي

بعيداً عن الكلي، كما صرح الثاطبي بذلك ' '.

لذا اعتتى الأصوليون بأهمية معرفة المفتي للمقاصد الثرعية، فقد أرشد

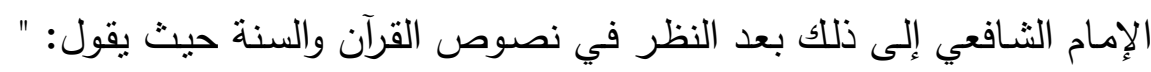

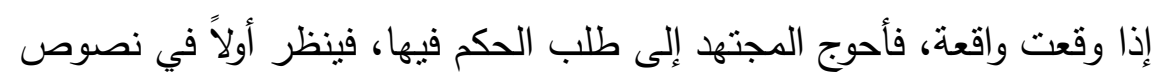

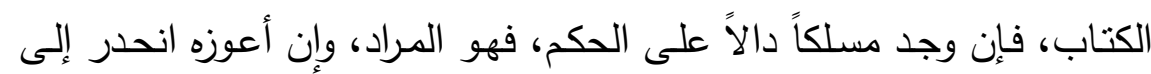

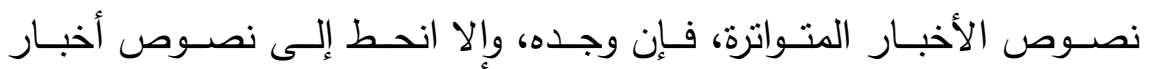

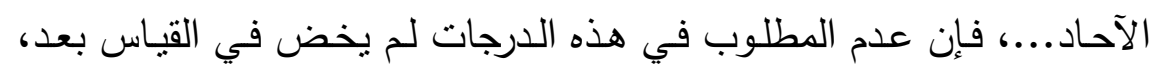
ولكنه ينظر في كليات الثرع، ومصالحها العامة "( "). وذكر الجويني أن من لم يتفطن لوقوع المقاصد في الأوامر والنواهي، ومهاك

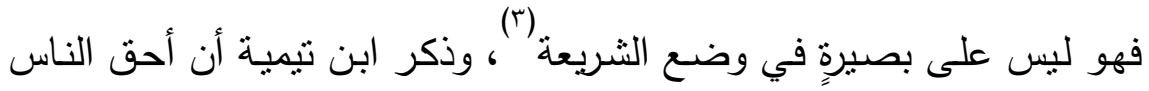

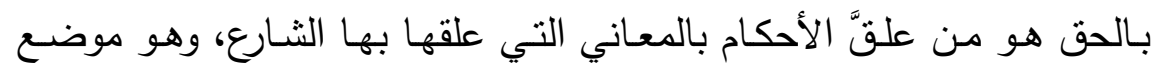

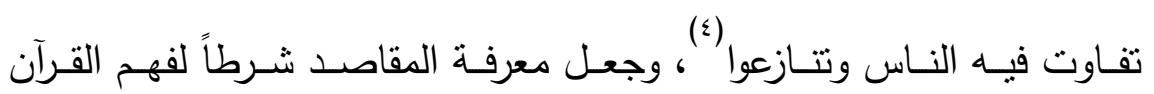

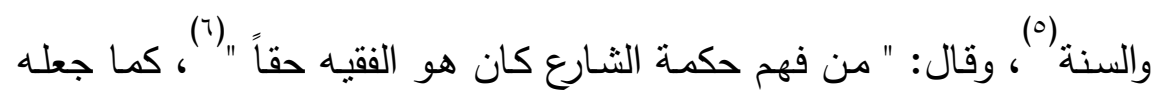

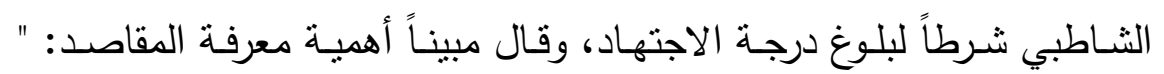
الاجتهاد إن تعلق بالاستتباط من النصوص، فلا بد من اثتراط العلم بالعربية،

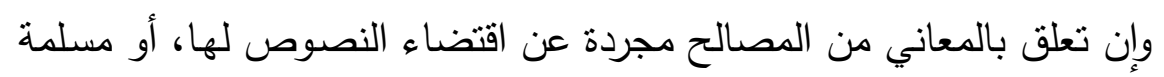

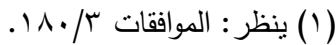

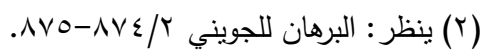

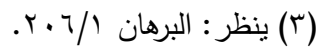

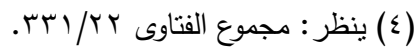

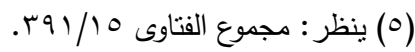

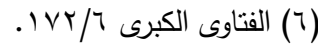


من صاحب الاجتهاد في النصوص، فلا يلزم في ذلك العلم بالعربية، وإنما بلزم العلم بمقاصد الثرع من الشريعة جملةً وتقصيلاً " (').

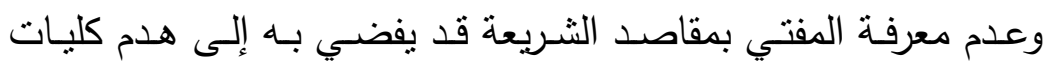

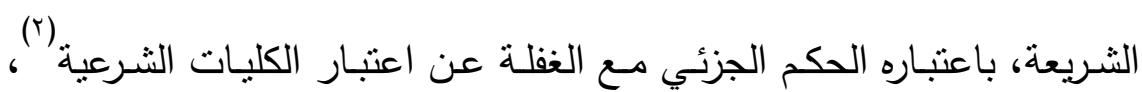

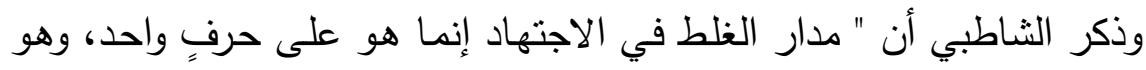

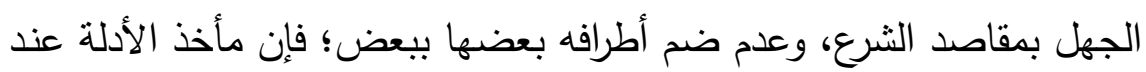

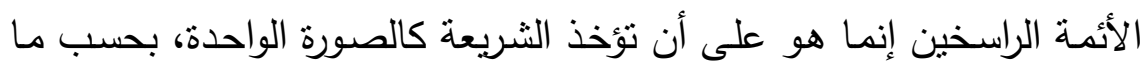

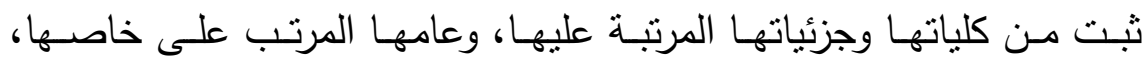
ومطلقها المحمول على مقيدها، ومجملها المفسر ببينها، فإذا حصل للناظر من ونه جملتها حكم من الأحكام، فذلك الذي نطقت به حين استتطقت "("). وقد جعل السبكي كمال رتبة الاجتهاد تتحقق في ثناثة أثنياء: " الأول: التكيف بالعلوم التي يتهذب بها الذهن، كالعربية، وأصول الفقه، وما يُحتاج إليه

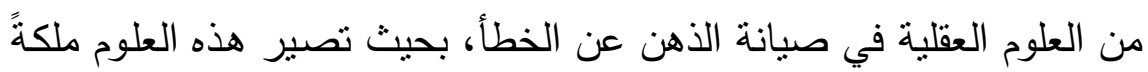

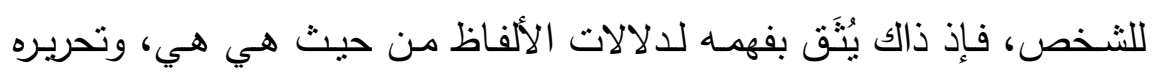
لصحيح الأدلة من فاسدها. الثاني: الإحاطـة بمعظم قواعد الثـريعة، حتى يَعـرف أن الدليل الذي ينظر فيه مخالف لها أو موافق. الثالث: أن يكون له من الممارسة والتتبع لمقاصد الثريعة ما يكسبه قوةً

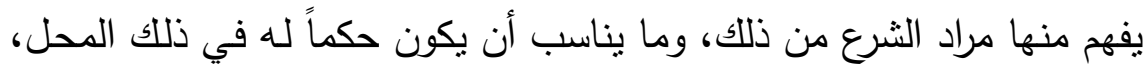

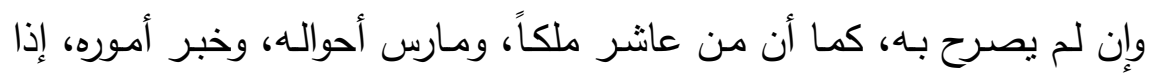

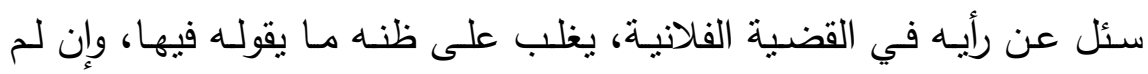


يصرح له بـه، لكن لمعرفته بأخلاقه وما يناسبها من تلك القضية، فإذا وصل

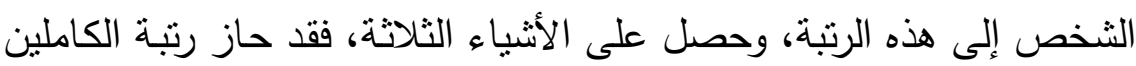

في الاجتهاد " (') - (1)

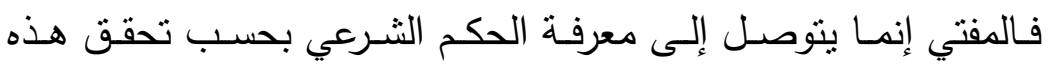

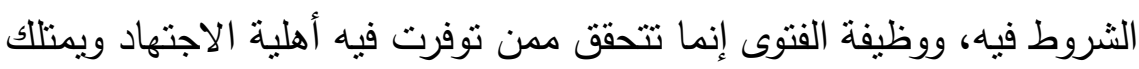

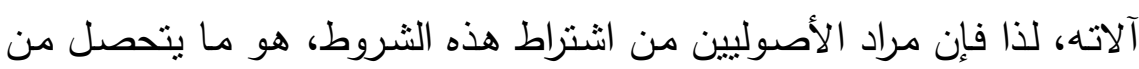

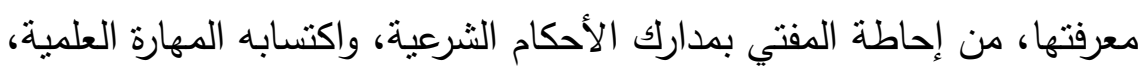
والدربة على ملكة الاستتباط والاجتهاد، وذلك بمعرفته ودرايته بطرق استفادة الأحكام الثرعية من النصوص، وطرق إثباتها، ووجوه دلالتها على مدلولاتها،

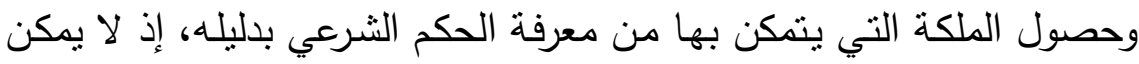

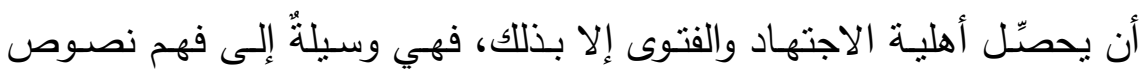

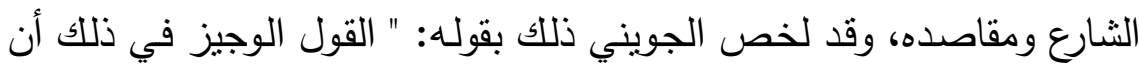
المفتـي هـ المـتمكن مـن إدراك أحكام الوقـائع على يسـر، مـن غيـر معانـاة

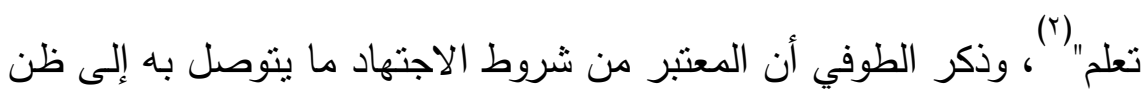

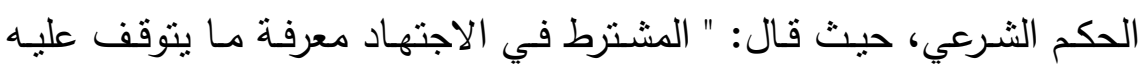
حصول ظن الحكم الثرعي، سواءُ انحصر ذلك في جميع ما ذكر ، أو خرج

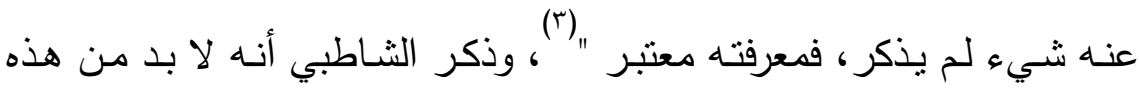
المعارف كوسيلةٍ إلى فهم مقاصد الثريعة على الأقل (؛ ل.

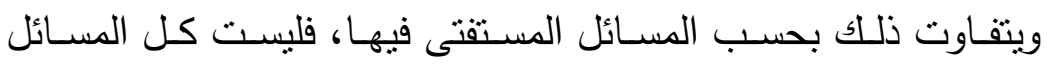

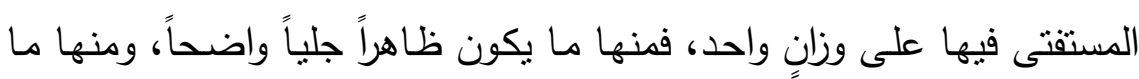

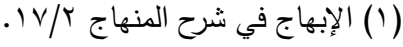

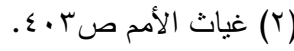

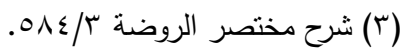

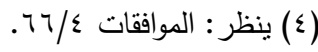


يكون خفياً ومعقداً، كبعض النوازل المعاصرة التي يتطلب النظر فيها ومعرفة

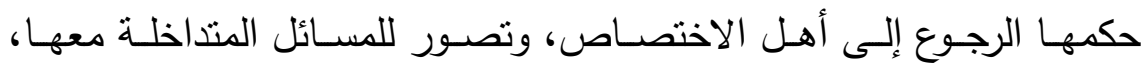

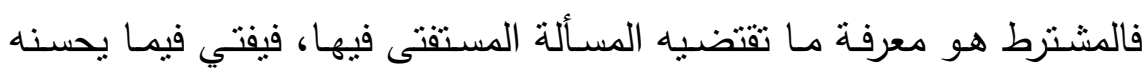

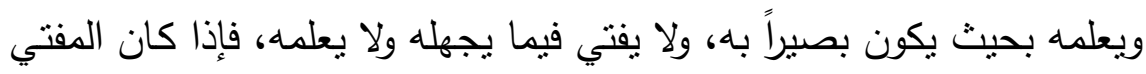

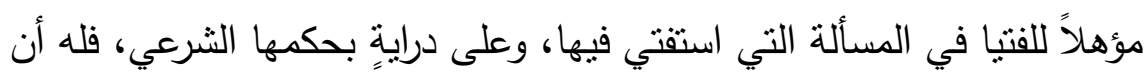
يفتي فيها، وإلا لم يجز لله الفتيا، وهذا مقتضى القول بتجزؤ الاجتهاد، فيفتي لهيني

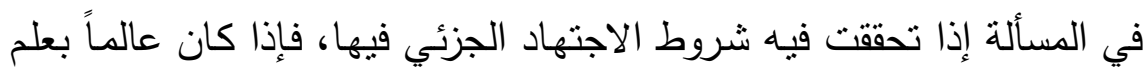

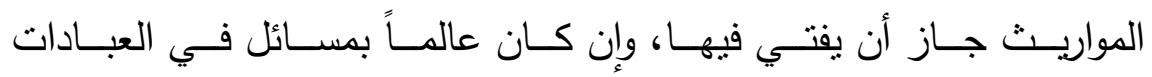
أو المعاملات جاز له أن يفتي فيها ' '. ومما ذكره الأصـوليون في شروط المفتي أن يكون ثقةًَ، عدلاً، أمينـاً،

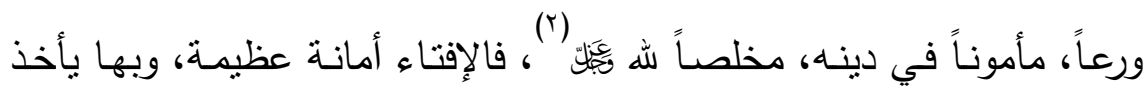

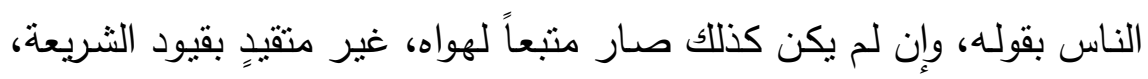
ميالاً للتساهل والتلاعب بالأحكام، يقول ابن السمعاني: "أعلم أن الثقة والأمانة

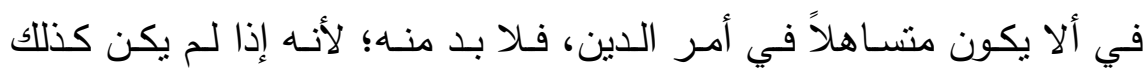

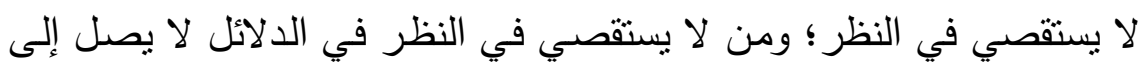

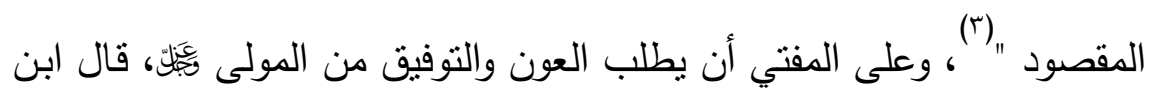

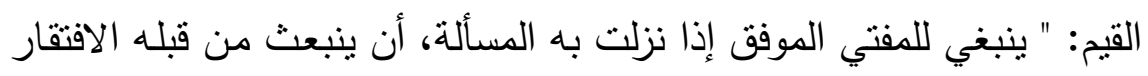

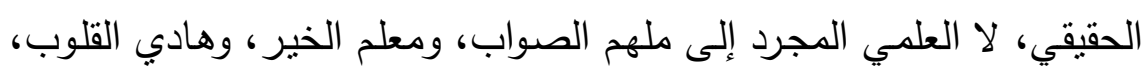

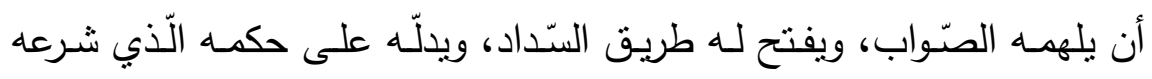

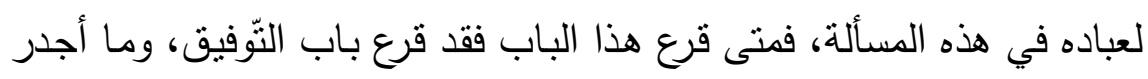

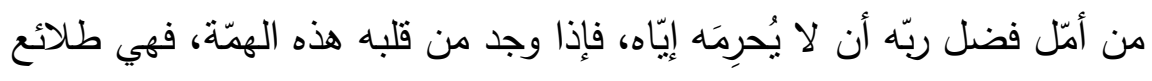

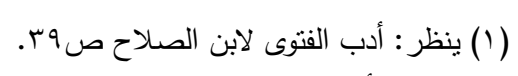

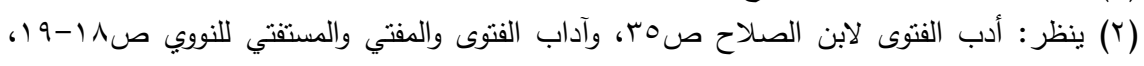

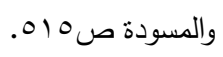

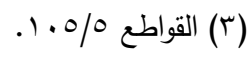


بشرى التّوفيق، فعليه أن يوجّه وجهه، ويحدق نظره، إلى منبع الهدى، ومعدن

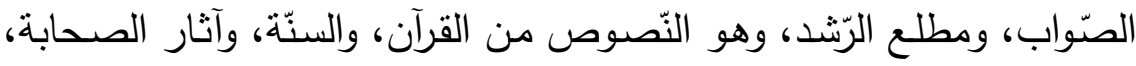

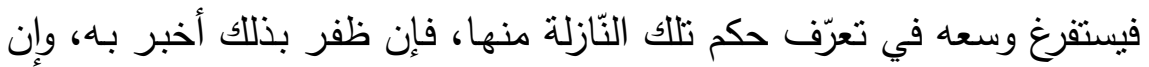

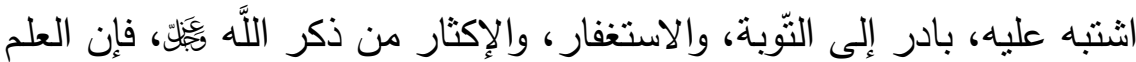

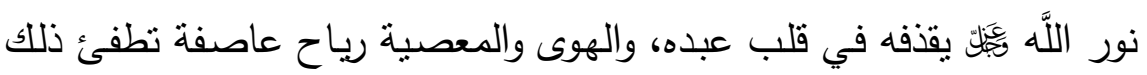

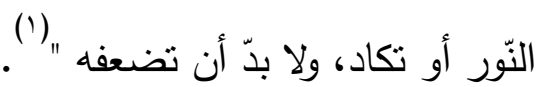

ومتى كان المفتي غير مؤهلٍ للفتيا، فإنه يقع في الخطأ ومجانبة

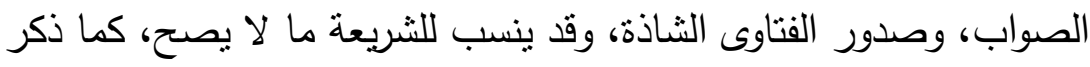
ابن تيمية عمن نسب للصحابة رضي الله عنهم جواز شرب النبيذ حيث قال: "

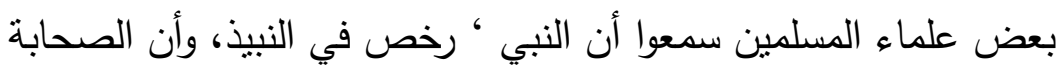

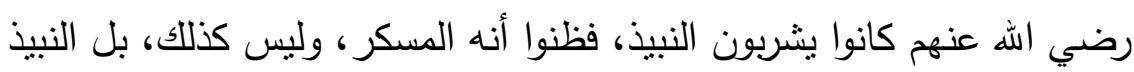

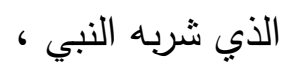
والصحابة رضي الله عنهم هو أنهم كانوا ينبذون التمر ، أو الزبيب، أو نحو لنوبه

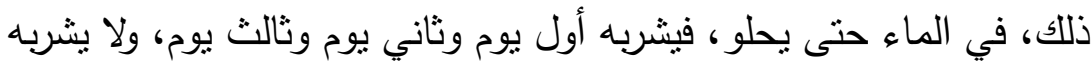

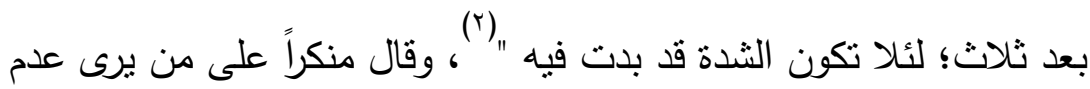

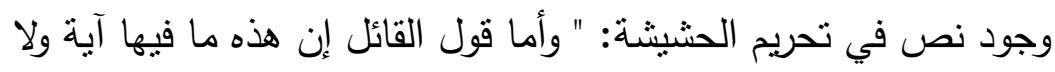

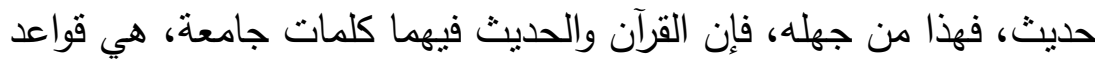
عامة وقضايا كلية، تتناول كل ما دخل فيها، وكل ما دخل فيها فهو مذكورٌ

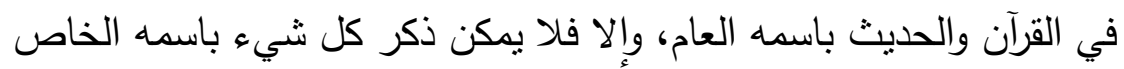
(r) 


\section{المبحث الثاني:}

\section{أن يتصــور المفتـــي المســأنــة:}

من ضوابط الفتوى أن يتصسور المفتي المسألة المستفتى عنها تصوراً

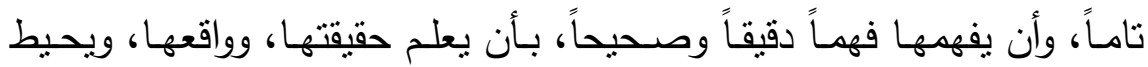
بجوانبها، وملابسـاتها، وأحوالهـا، وصـورها، مدركاً لألفـاظ المسـتفتي، فاهمـاً

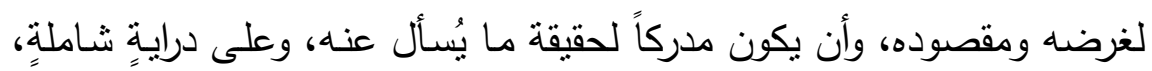

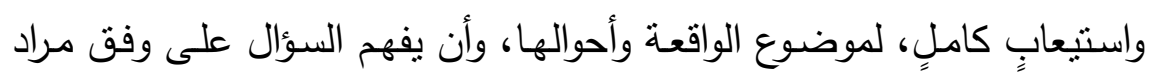

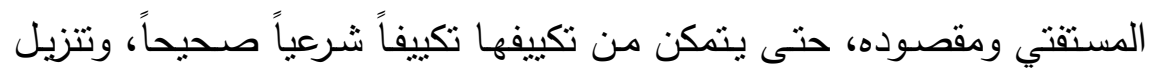

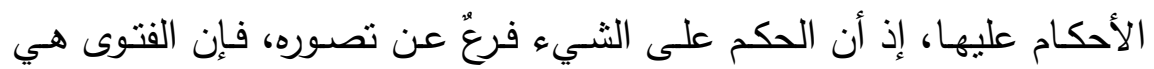

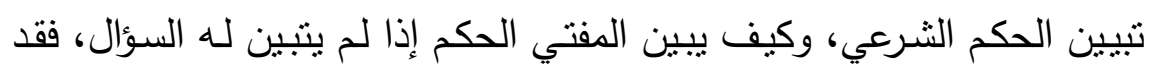

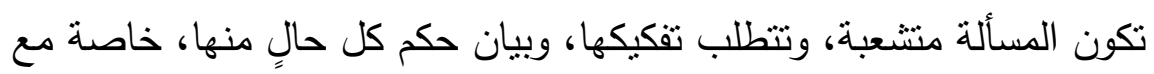
كثرة المستجدات المعاصرة، وتداخلها وتعقبدها، ومتى لم يكن المفتي على درايةٍ بالمسألة المستفتى فيها، أو لم ينظر فيها، لم يجز له أن يفتي فيها، قال الإمام

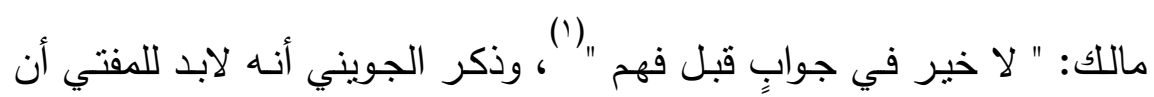

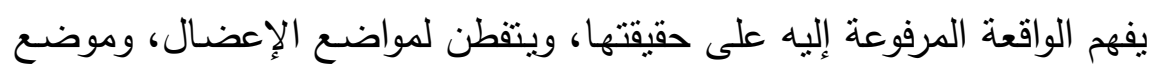

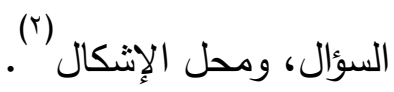
ويقول ابن السبكي: " فعلى المفتي أن يعتبر ما يُسأل عنه، وأحوال تلك الك

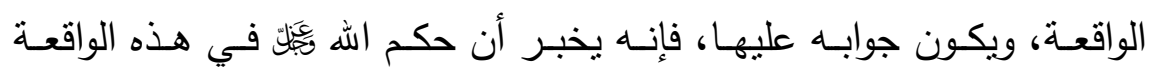
كذا "(r)

وقد يتطلب فهم المسألة استفصال المستفتي عما يحتاج إلى استفصالٍ

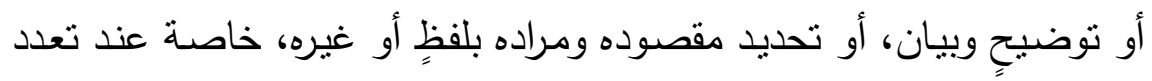

$$
\begin{aligned}
& \text { (1) ينظر : الفقيه والمتفقه للخطيب البغدادي ك/r) }
\end{aligned}
$$

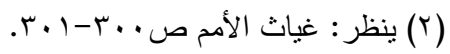

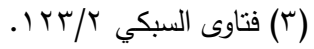


الاحتمالات، أو يتطلب منه الرجوع إلى أهل الاختصاص والخبرة، والاستفسار

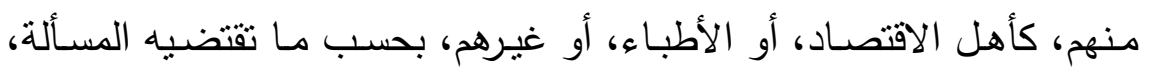

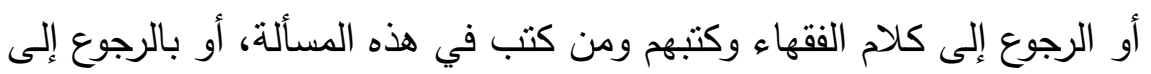

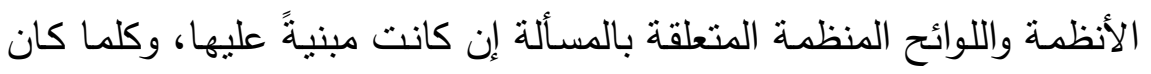
المفتي دقيقاً في فهم المسألة وتصورها، كلما كانت الفتوى أقرب إلى الصواب.

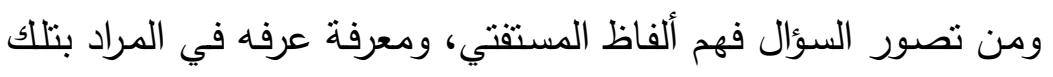

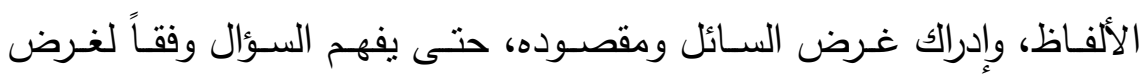

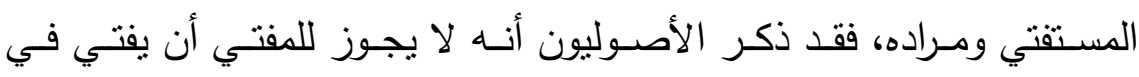

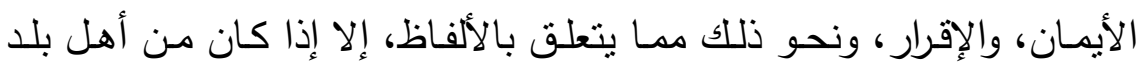

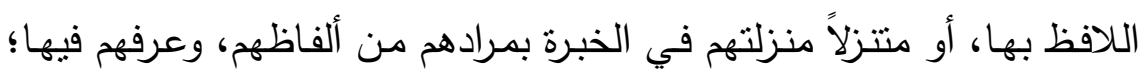
لأنه إذا لم يكن كذلك كثر خطؤه عليهم في ذلك (') لأن العرف قرينةٌ حاليةٌ يتعين الحكم بها، ويختل مراد اللافظ مع عدم مراعاتها '(ب).

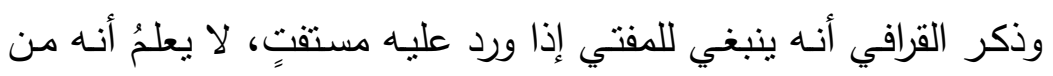

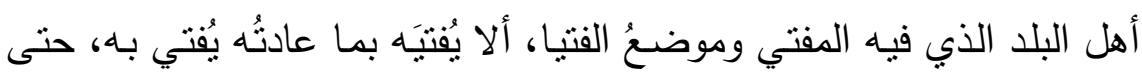

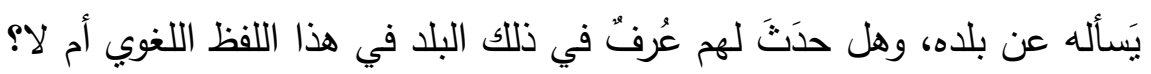

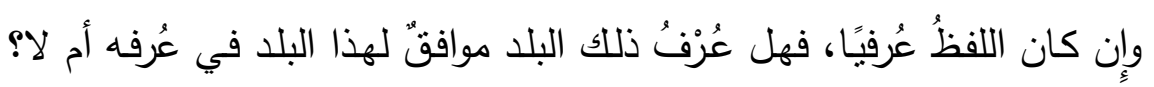

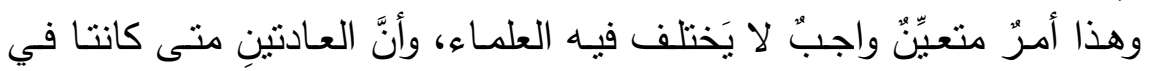

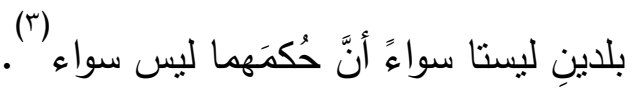

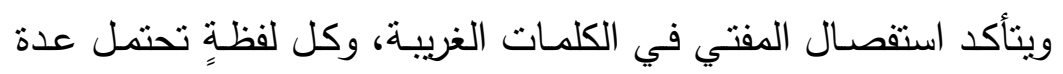

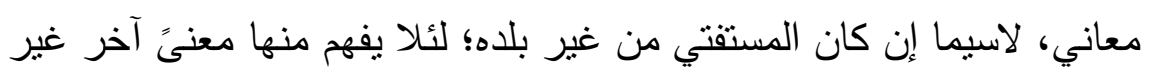

(1) ينظر : أدب الفتوى لابن الصلاح ص الط، وآداب الفتوى للنووي ص. ؛، وصفة الفتوى لابن حمدان

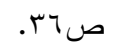

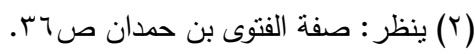

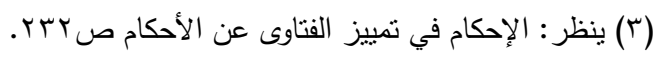


مـا اعتاده هو من فهم تلك الألفاظ، ويكون على خـلاف مراد المستفتي، كي

تكون الفتوى منوافقةً مع السؤال، ولا تكون مخالفةً، فتكون فتوى خاطئة ' '.

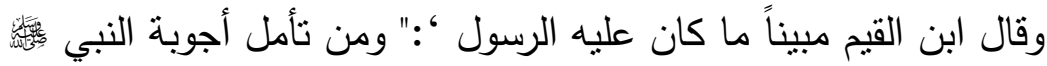
رآه يستفصل حيث تدعو الحاجة إلى الاستقصال، ويتركه حيث لا يحتاج إليه،

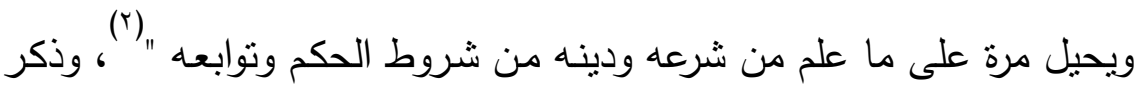

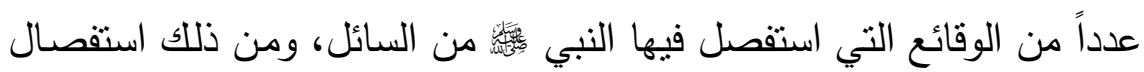

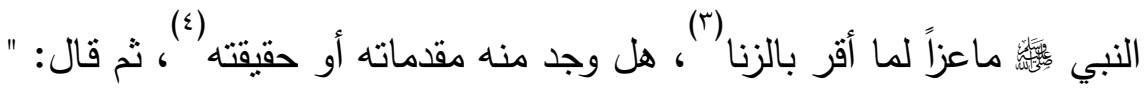

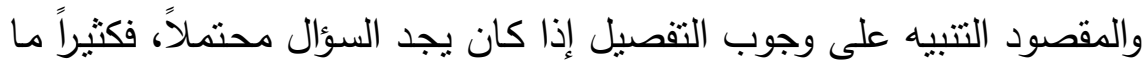
يقع غلط المفتي في هذا القسم، فالمفتي ترد إليه المسائل في قوالب منتوعةٍ

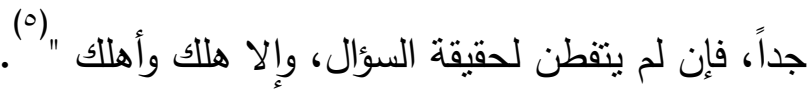
كما على المفتي ألا يقف على ذات اللفظ والمصطلح قبل معرفة والات والهة معناه

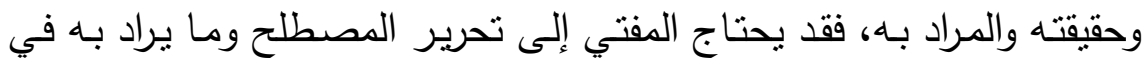

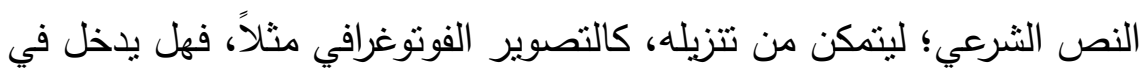

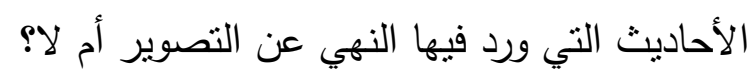
وإن عدم تصور المفتي للمسألة على حقيقتها يفضي إلى خطأ الفتوى النى ومجانبة الصواب، وعدم صحة تنزيلها على الواقعة المسؤول عنها، إذ قد تكون المسألة المستفتى عنها لها عدة تصور ، فيسأل عن أحدها، وتكون فتواه متعلقةً

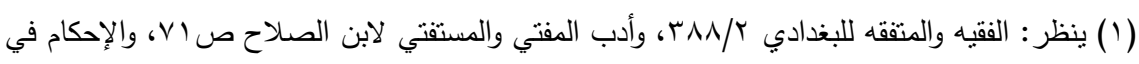

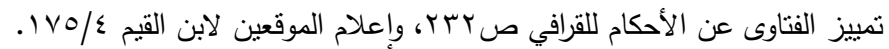

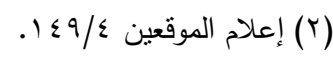

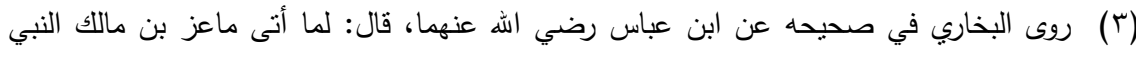

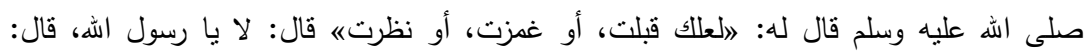

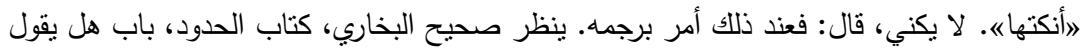

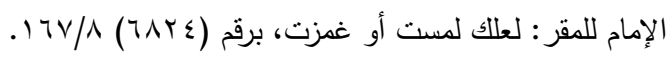

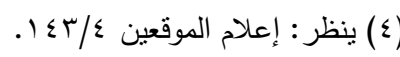

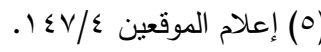


بصورة أخرى، كما مثناً في مسألة الإجارة المنتهية بالتمليك، أو الزواج بنيـة

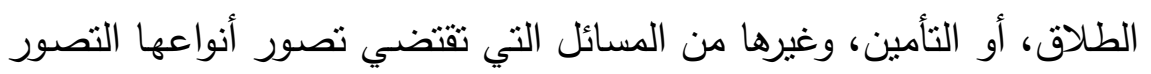
التام قبل الفتيا.

ولعدم تصور المفتي للمسألة أسباب، منها: تسرع المفتي في الإفتاء قبل

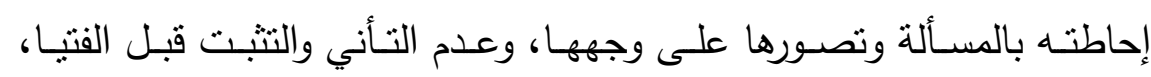

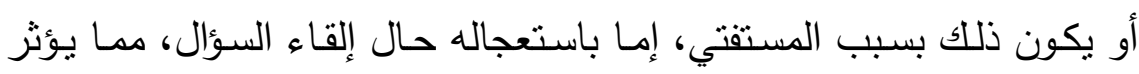

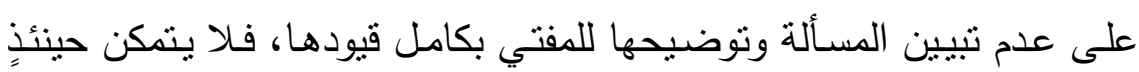

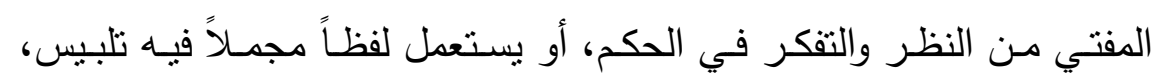

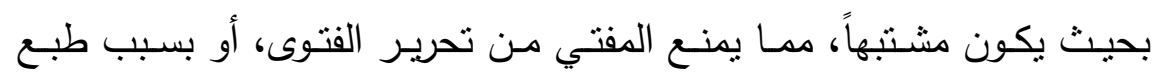

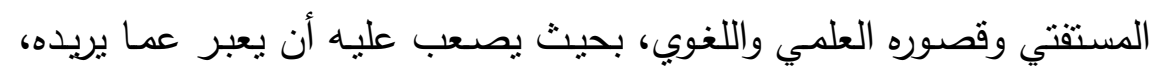

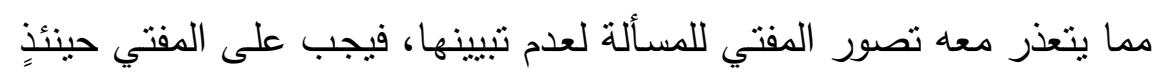

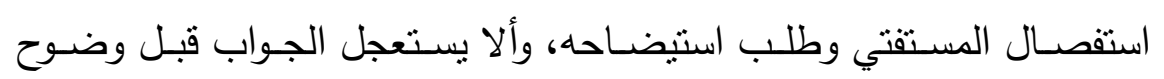
السؤال. ونظـراً لمـا لحسـن صـياغة المسـتفتي للسـؤال مـن تـأثير على الفتوى

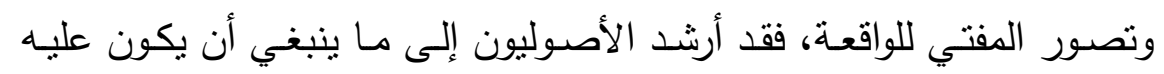

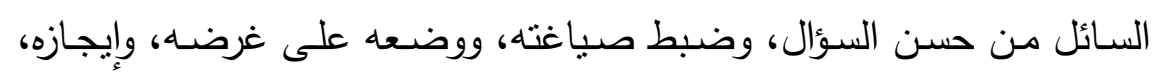

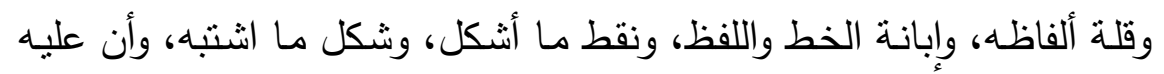
تعلم آداب السؤال؛ كي يسأل سؤالاً واضحاً ومختصراً، يتمكن المفتي من فهـهـ بيسرٍ وسـهولة ')، وفي هذا يقول شيخ الإســام ابن تيميـة: " حسن السؤال نصف العلم، إذا كان السائل قد تصور السؤال "( '.

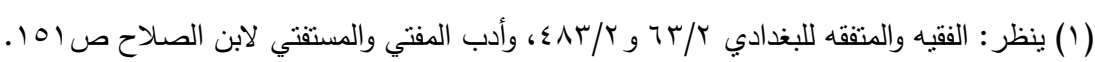

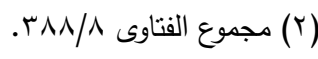




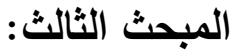

أن تكون الفتـوى مبنـــة على أصـلٍ شرعـي مـعتبـر

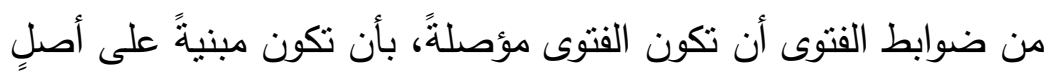

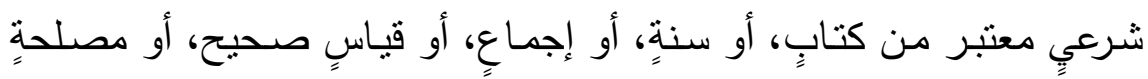

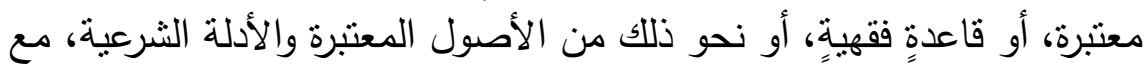

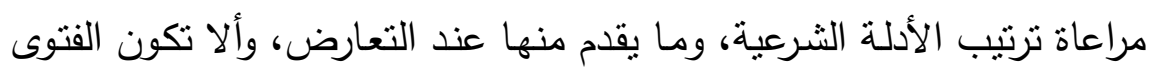

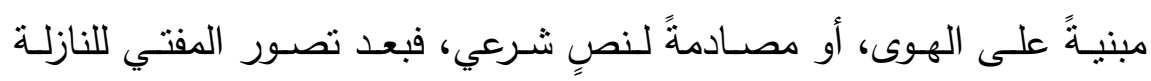
المستفتى فيها، عليه أن يعرضها على النصوص الثرعية، والقواعد الأصولية، وهذا يتطلب معرفة واستحضسار أدلة الثريعة، وقواعدها، ومقاصدها، والموازنة

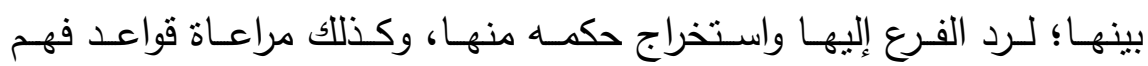

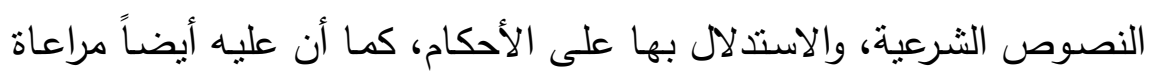

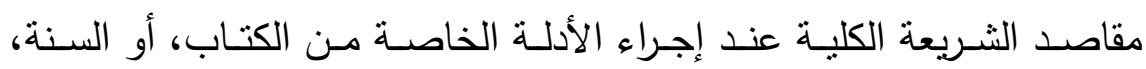

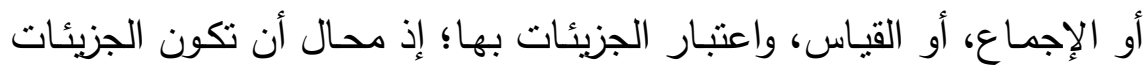
مستغنية عن كلياتها (') لئلا يفضي ذلك إلى تخلف مصلحة الفعل المقصودة الفئان

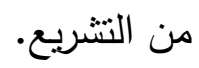
يقول ابن عبد البر : " إن الاجتهاد لا يكون إلا على أصولٍ يُضاف إليها

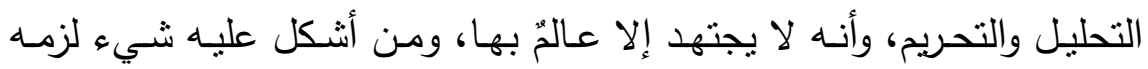

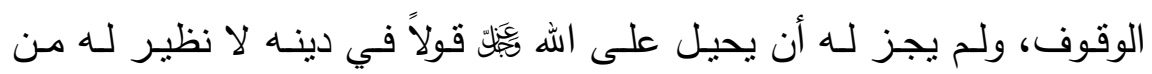
أصل، ولا هو في معنى الأصل، وهذا لا خلاف فيه بين أمة الأمصار قديماً

وحديثاً "( ")

وقد أبـان الأصـوليون بالتفصيل الكـلام عن الأدلـة الثـرعية، وضـوابط

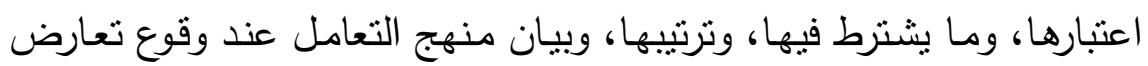


فيما بينها، والاعتراضـات التي يمكن أن ترد عليها، وغير ذلك، بمـا يضمن صحة الدليل المستدل به في المسألة.

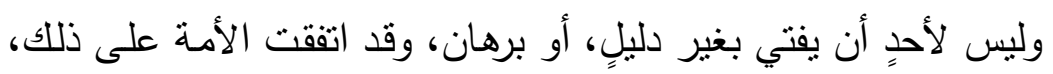

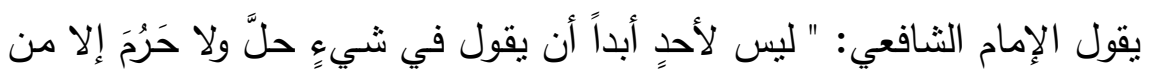

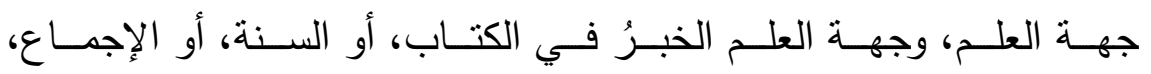
أو القياس "(') وبقول ابن حزم: " كل قولٍ بمجرد الدعوى بـلا برهـان، فهو

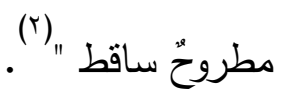

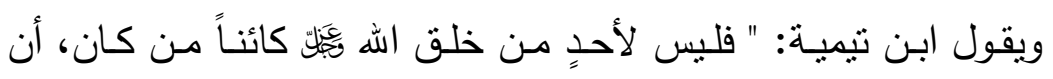

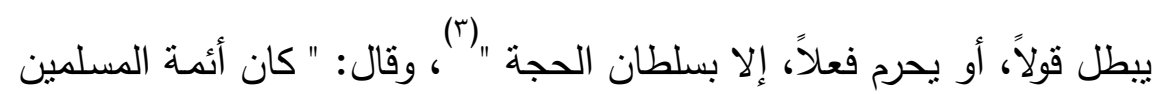

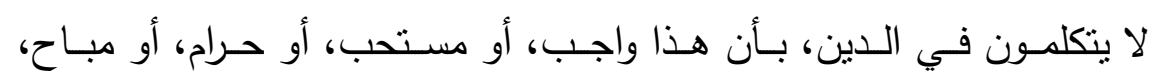

إلا بدليلٍ شرعي من الكتاب، أو السنة، وما دلا عليه (؛)".

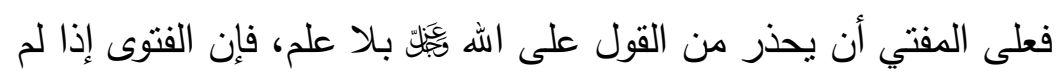

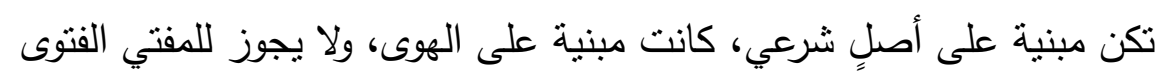
بالهوى (ْ) فقد نقل ابن تيمية إجماع العلماء على تحريم الحكم والفتيا بالهوى،

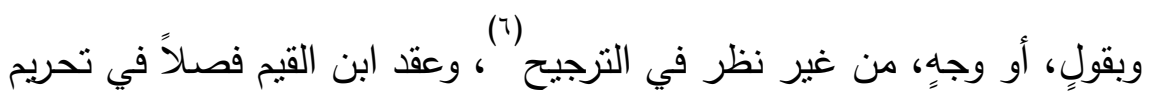

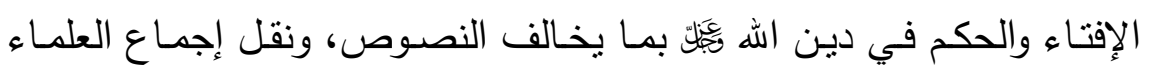

على ذللك (v).

\begin{tabular}{|c|}
\hline (1) الرسالة ص9 ؟. \\
\hline 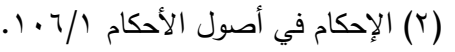 \\
\hline 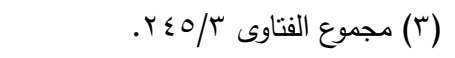 \\
\hline (乏) مجموع الفتاوى VVT/Kr \\
\hline 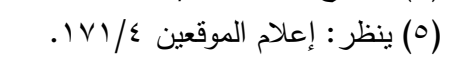 \\
\hline (ך) ينظر : الفتاوى الكبرى 000/0. \\
\hline (V) ينظر : إعلام الموقعين rVq/r. \\
\hline
\end{tabular}


ولكي يتمكن المفتي من البناء على أصلٍ شرعي في النازلة، ورد الفروع

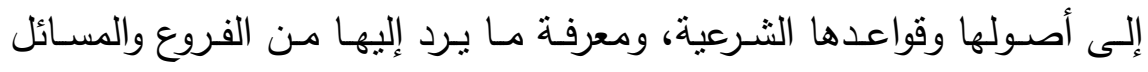

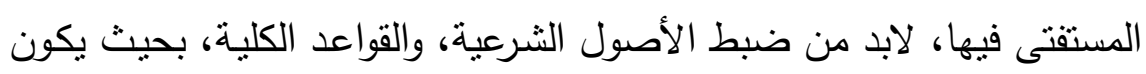

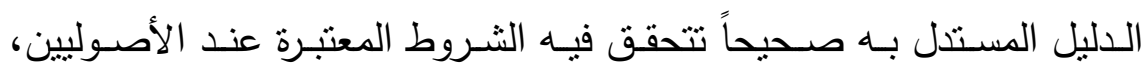

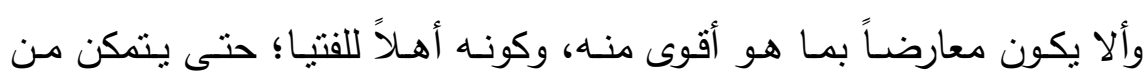

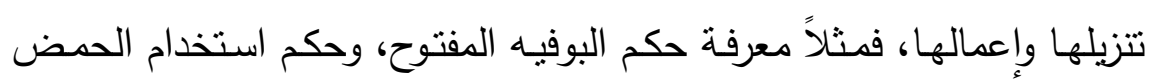

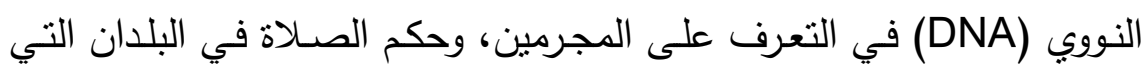

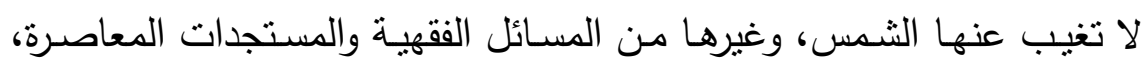

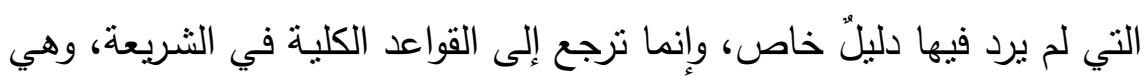

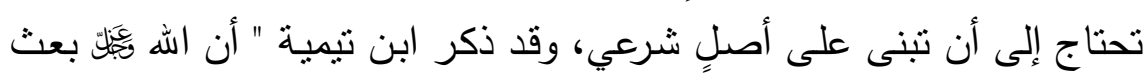

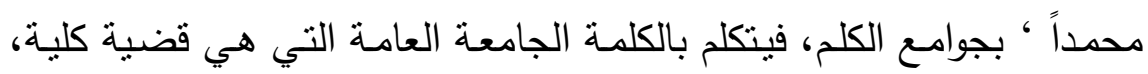

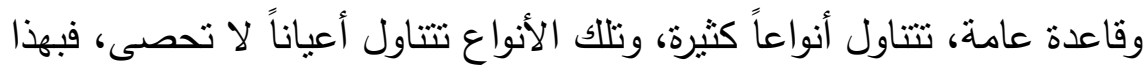
الوجه تكون النصوص محيطة بأفعال العباد " ('). 


\section{المبحث الرابع:}

\section{أن تكـون الفتـوى مراعيـة لحسال المستفتــي:}

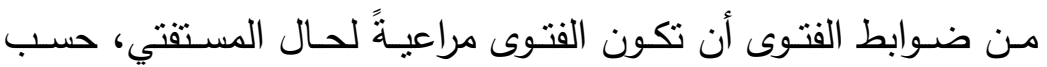

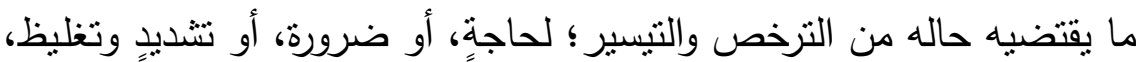

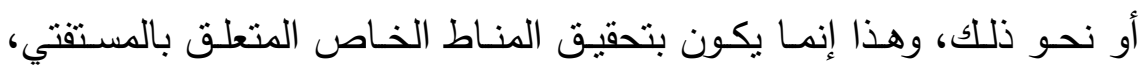
واعنبار حاله وظرفه وقصده، وقد ذكر الأصوليون في شروط المجتهد اشتراط

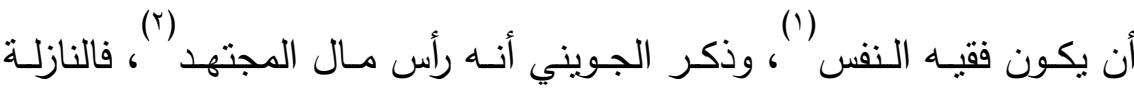
الواحدة قد يختلف حكمها من مستفتي لآخر بحسب حاله. فالفتوى يجب تحقيقها لمقاصـ الثـريعة في آحساد المستقنتين، وأن ينت تتزيـلـل النصـوص الثـرعية على الوقـائع، وهــا إنمـا يتحقـق بمراعـاة حـال

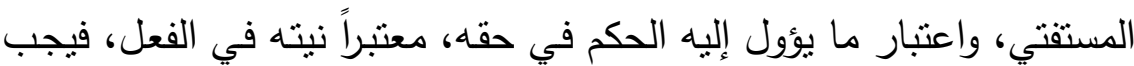

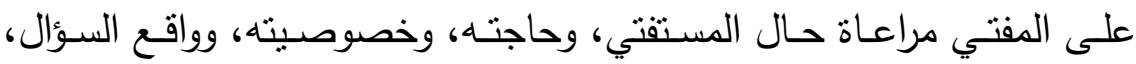

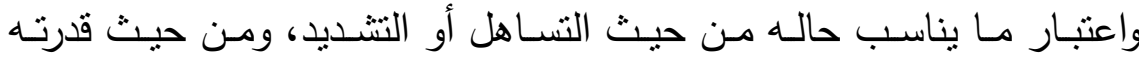
واستعداده، وعقله وفهمه، فيفتي كل مستقدٍ بما يناسب حاله، تارةً بما يقتضي

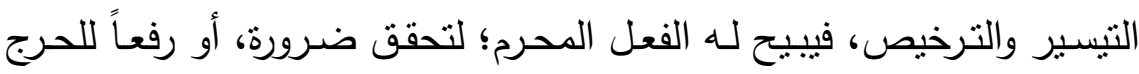
والمشقة، وتارةً بما يقتضي التغليظ والزجر ، بحسب المصلحة التي تقتضيها اعتبـار حالـه، ويحمل المستفتي على الوسط، فـلا يـذهب بـه مـذهب الثـدة،

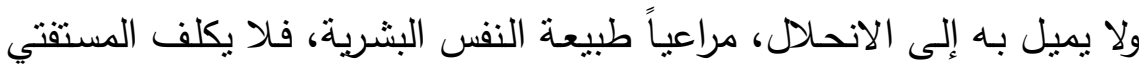

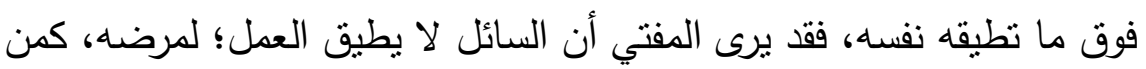

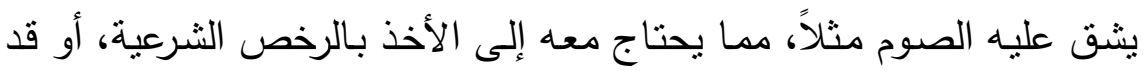

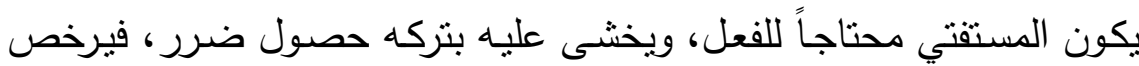
له، كما ينظر المفتي أيضاً في مآل الفعل في حق المستفتي، فقد يكون المباح 
مفضياً بـه إلى الوقوع في محظور ، أو مسبباً لـه الوقوع في مشقة زائدة عن

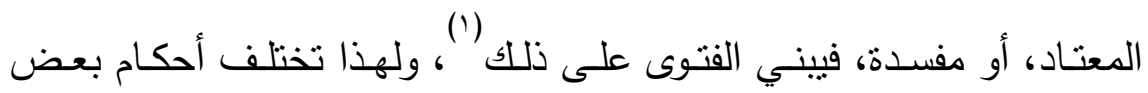
المسائل الفقهية تبعاً لحال المستفتي، ومـا يؤول إليـه الفعل في حقهـ، كحكم

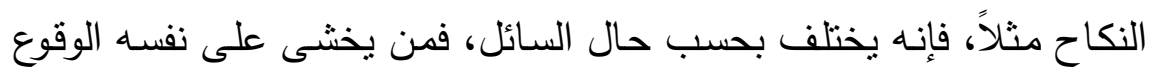
في الزنا يكون واجباً في حقه، بخلاف من لم يخش في حقه ذلك، فإنه يكون

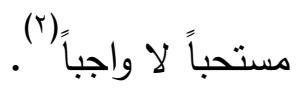

ولن يتمكن المفتي من نتزيل النصـوص الثـرعية على المستقتي دون

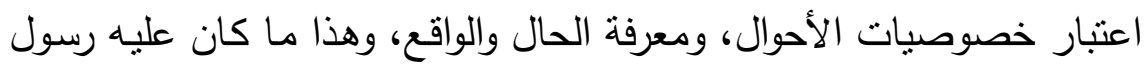

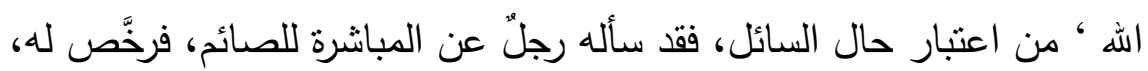
ثم أتاه آخر فنهاه ") فكان الذي رخص لله شيخ، والذي نهاه شاب، إذ القبلة

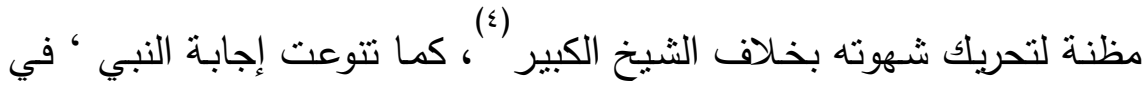
أفاضل الأعمال، لما سئل ، في أوقاتٍ مختلفة عن أفضل الأعمال، فأجاب

بإجاباتٍ مختلفة بحسب حال السائل (•). ومن اعتبار حال المستفتي النظر في قصده ونيته، بأن يكون قصده

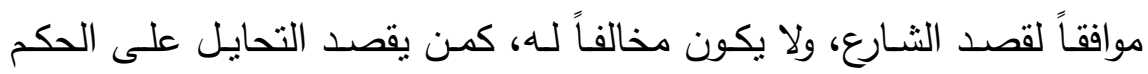

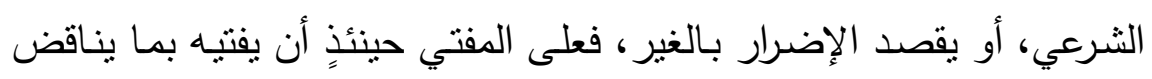

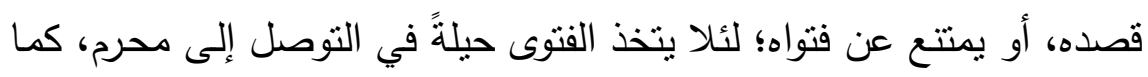

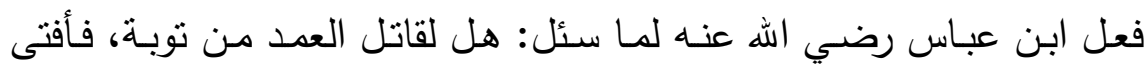

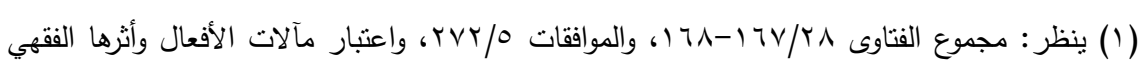

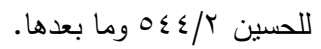

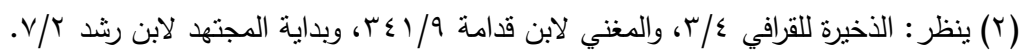

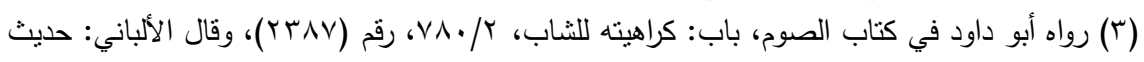

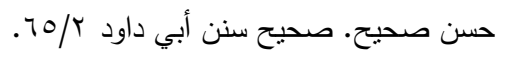

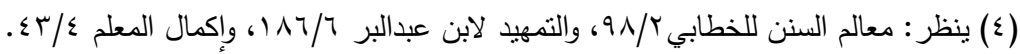

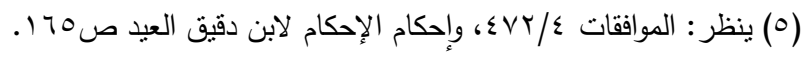


سائلاً بأن له نوبة، وأفتى آخر بأنه ليس له توبة؛ لما رأى من حاله أنه يريد أن

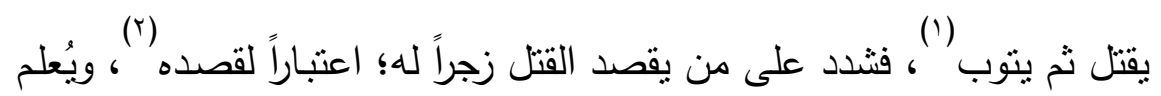

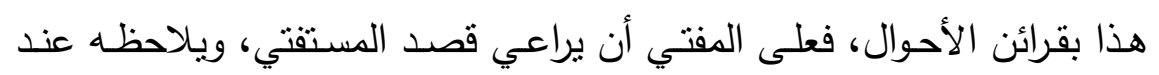

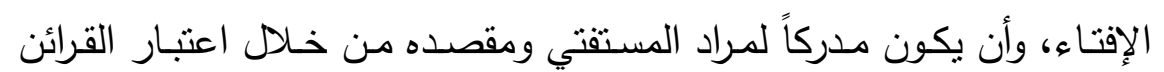

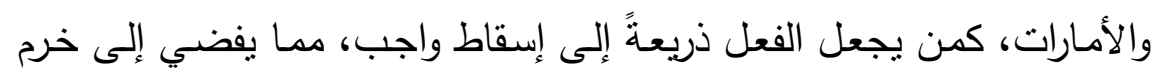

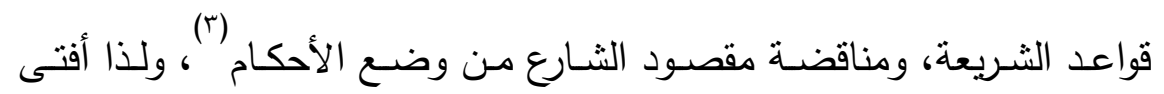

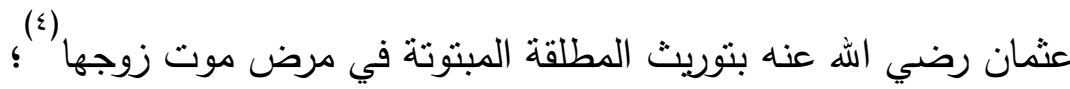
يكون طلاقها في نلك الحال ذريعةً إلى قصد حرمانها من الميراث (ه).

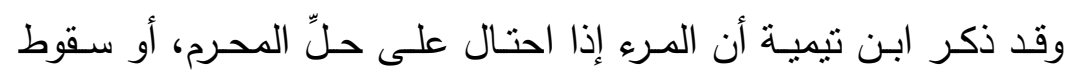

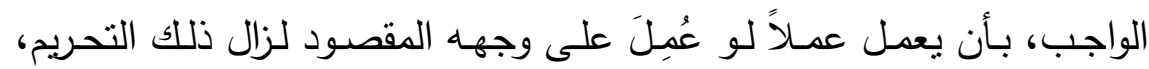

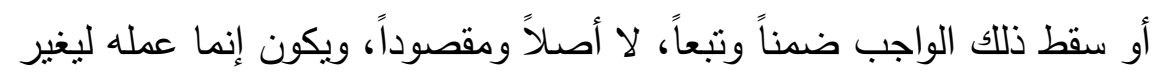

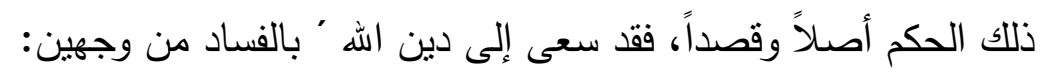

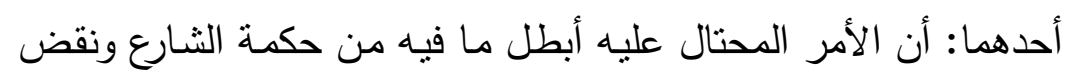

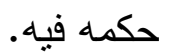
الثاني: أن الأمر الدحتال به لم يكن له حقيقةً، ولا كان مقصوداً، بحيث

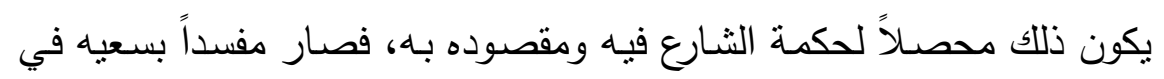

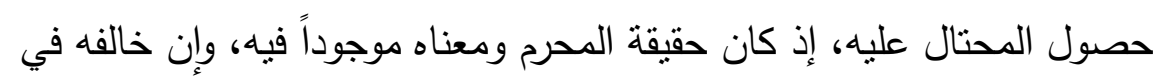

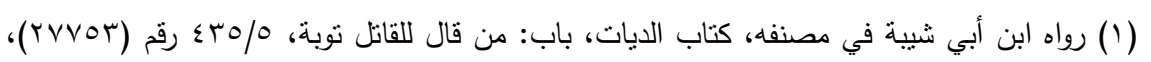

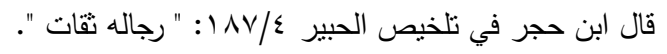

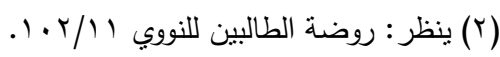

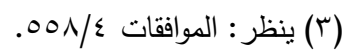

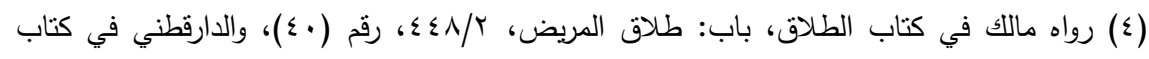

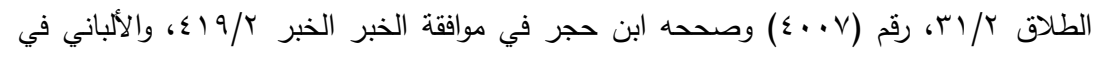


الصـورة، ولـم يكن مصـلحاً بـالأمر المحتـال بـهـ إذ لـم يكن لـه حقيقـة عنـده

ولا مقصود ')

وذكر أيضـاً أن المقاصـ تغير أحكام التصـرفات مـن العقود وغيرهـا،

مستشهـداً بعددٍ من النصوص الثـرعية الدالة على ذلك (ז)، وقد حرم الشـارع

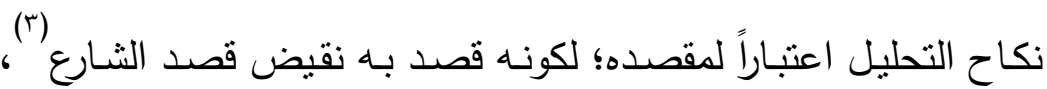

الفقهاء من بيع العنب لمن يتخذه خمراً اعتباراً لنيته ومقصوده (؛ .

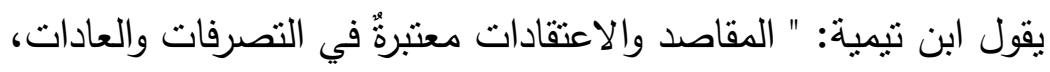

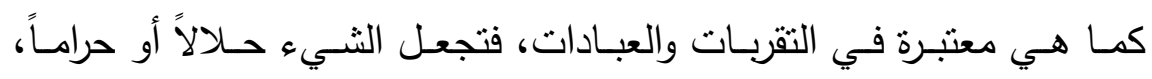

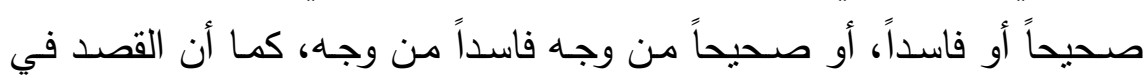

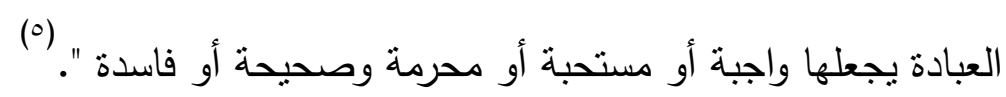

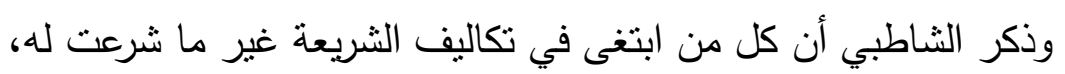

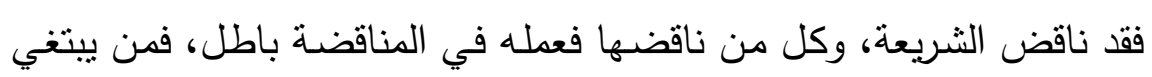

في التكاليف ما لم تشرع له فعمله باطل '· '. ولا يجب على المفتي حينئذٍ مساعدة المستفتي في سوء قصده، وألا يعينه في الوصول إلى مراده إن كان حراماً؛ لأنه لا يريد الحق، وإنما يربد غرضهـه،

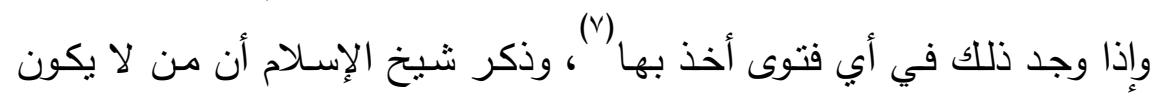

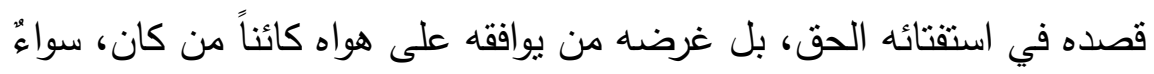

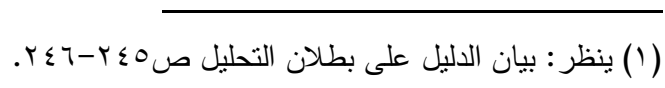

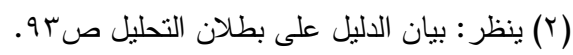

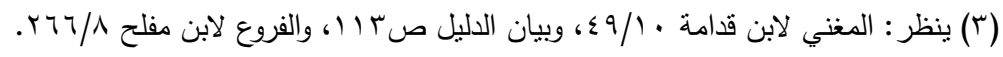

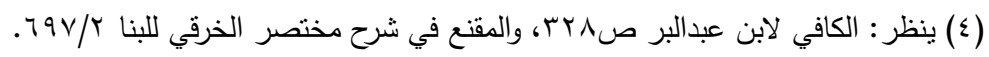

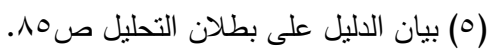

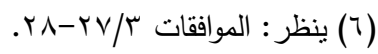

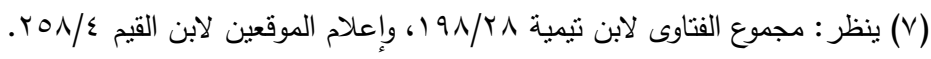




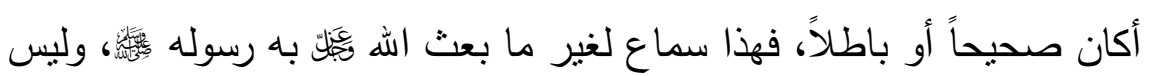

على المفتي أن يفتيه وحاله كذلك (')

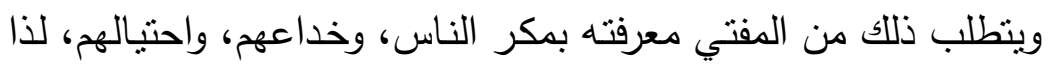

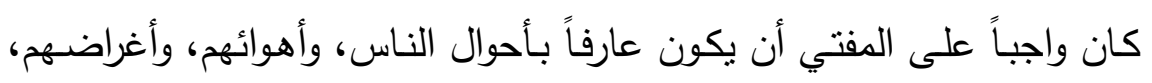
متفطناً لحيل المستفتين، وخداعهم، ومكرهم، وتلاعبهم بالألفاظ، وأن يكون حذراً

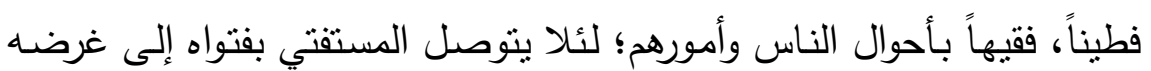

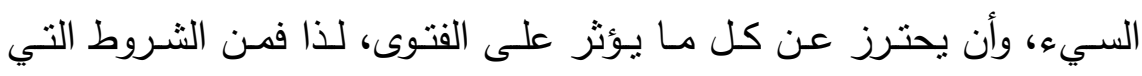

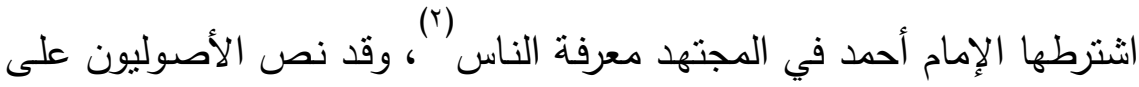
أن المفتي إذا رأى بياضاً خالياً خلال السطور ، ويحتمل أن يلحق بـه المستفتي

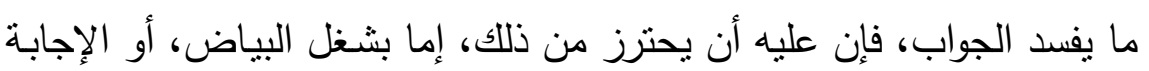

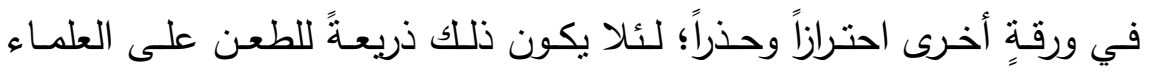

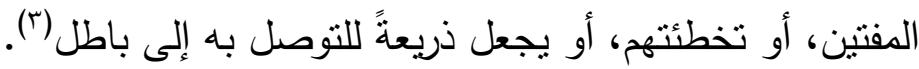

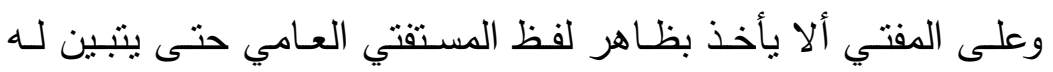

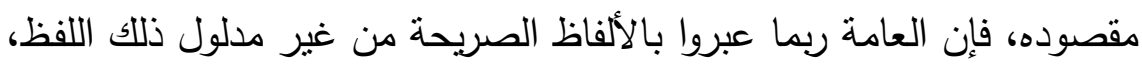

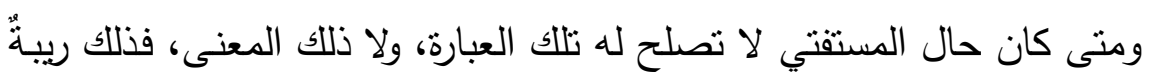
ينبغي الكثف عن حقيقة الحال كيف هو ، ولا يعتمد فقط على لفظ المستفتي، فإذا تحقق الواقع في نفس الأمر ما هو أفتاه، وإلا فلا يفتيه مع الريبة فـأ، وقد

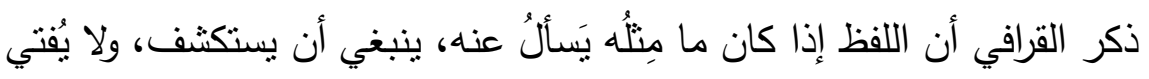

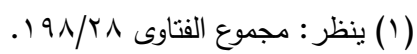

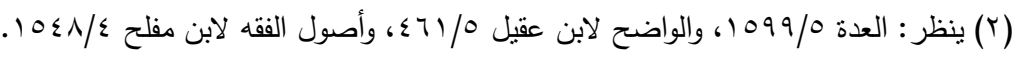

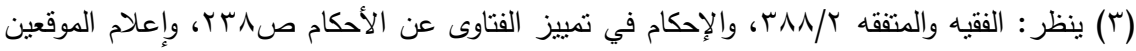


بناءً على ذلك اللفظ، فإن وراءه في الغالب مرميً هو المقصود، ولو صرح بـه

امتتعت الفتيا (')

وقال ابن عقيل مبيناً أثر معرفة المفتي للناس على الفتوى: " ومعرفة

الناس الفاجر الذي لا يستحق الرخص والتسهيل عليه، فئلزم عليه العزائم، ولو

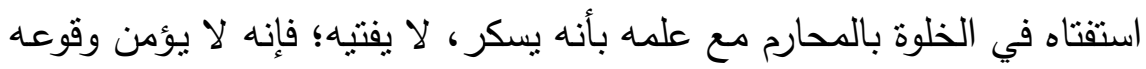

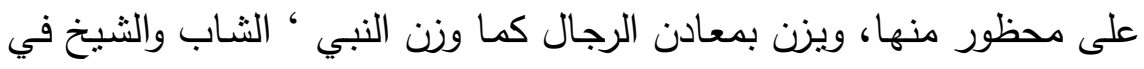

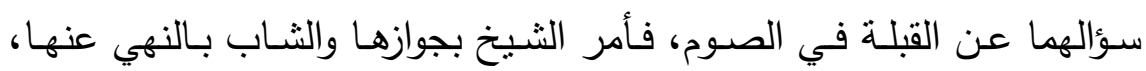
وكذلك رخص السفر لا يفتى بها أجناد وقتتا لمعرفتتا بأسفارهم، فهذا وأمثاله

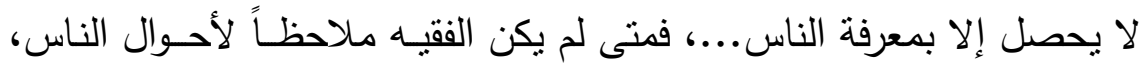

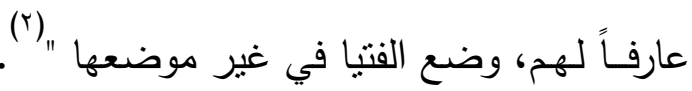

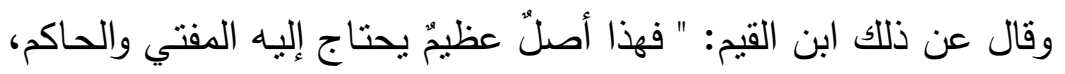

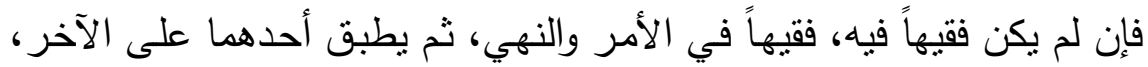

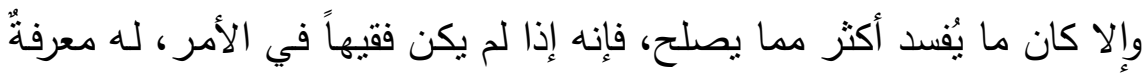

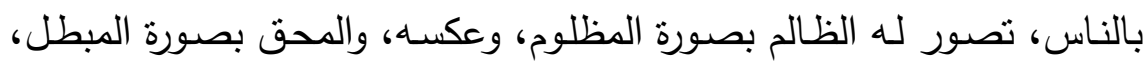
وعكسه، وراج عليه المكر والخداع والاحتيال، وتصور لله الزنديق في صورة

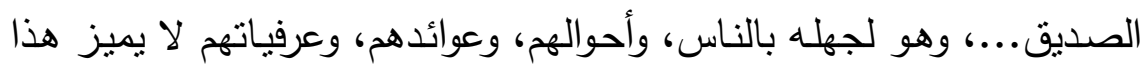

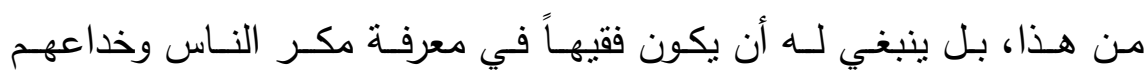

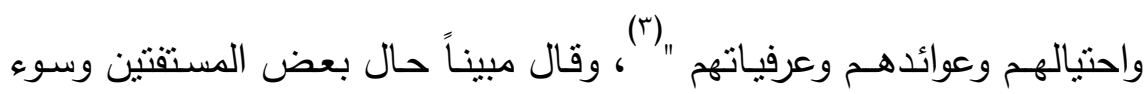
القصد في استفتائه، وكثرة وقوع منل ذلك منهم:" وكم من باطلٍٍ يخرجها الرجل

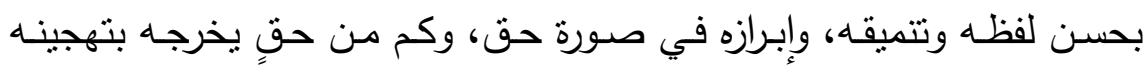

$$
\begin{aligned}
& \text { (1) ينظر : الإحكام في تمييز الفتاوى عن الأحكام صلوسY. }
\end{aligned}
$$

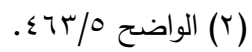

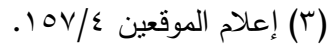


وسوء تعبيره في صورة باطل، ومن له أدنى فطرة وخبرة لا يخفى عليه ذللك، بل هذا أغلب أحوال الناس، ولكثرته وشهرته يستغنى عن الأمتلة" (')

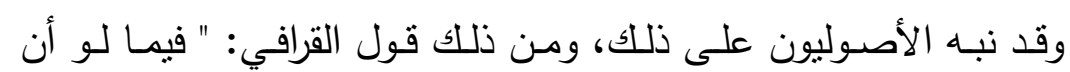

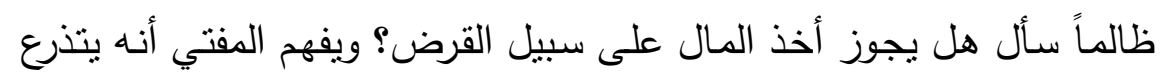

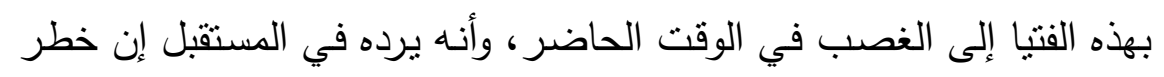

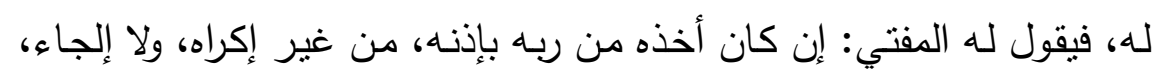

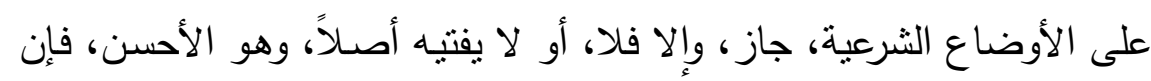

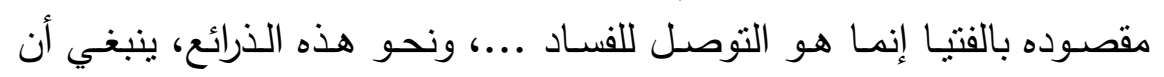

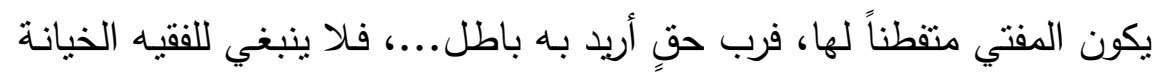

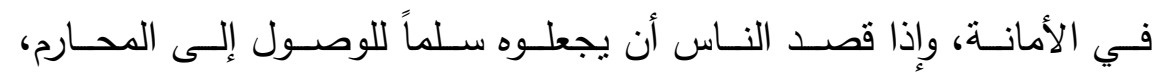
فلا يساعدهم على ذلك "(r). 


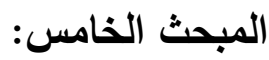

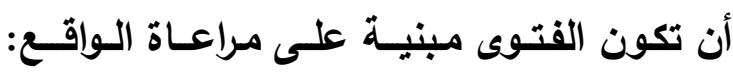

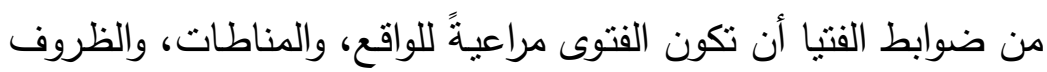
المكانيـة، والزمانيـة، واعتبـار مـا يحتف بالواقعـة وقت صدورها، إذ أن الفتاوى والأحكام تتغير بتغير وتبدل الأزمنة، والأمكنة، والأحوال، والعوائد، والأعراف،

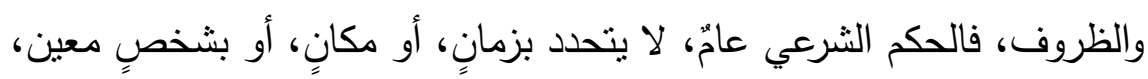
ولا يتعلق بالوقائع الجزئية، وكل حالةٍ وظرف لها ما بناسبها من النظر والحكم، فعلى المفتي بأن يكون محيطاً بفقه الواقع، بصيراً بزمانه، فاهماً لواقعه، عالماً

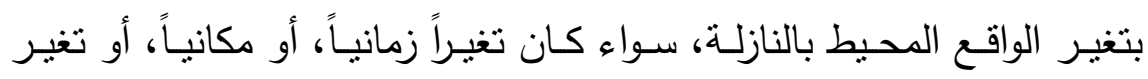
الأحوال والظروف، ومراعاته عند الإفتاء، وألا يعتمد على المنقول في الكتب فقط دون اعتبار للواقع، وما يقتضيه تغير الحال، والزمان، والمكان، واختلاف الأحــوال والظـروف، وتجـدد العـادات والأعـراف، واعتبـار العـرف المتجــدد والمتغيـر ؛ لأن الظـروف المحتفـة بالواقعـة تـؤثر في حكمهـا الثـرعي، إذ قـد يختلف حكم الواقعة عما كانت عليه سابقاً، أو من بلدٍ لبلد، أو من زمنٍ لزمن؛ لاختلاف واقعها.

فالواجـب على المفتي أن يعمل على المواعمـة بين الأحكـام الثـرعية،

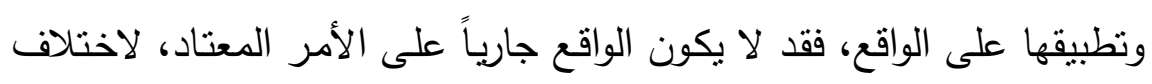

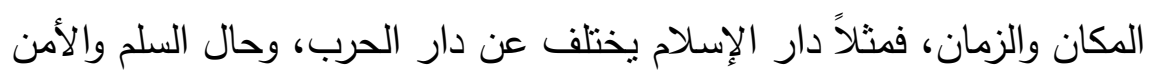
يختلف عن حال الخوف والحرب، وعلى المفتي أن يتحقق من مناط الحكم، بمعرفة مـا يؤثز فيه، ويكون سبباً في تغيره؛ حتى لا تتتمي الفتوى إلى زمنٍ غير الزمن، أو تعالج واقعاً غير الواقع المعاصر؛ لأن الأحكام تتغير بتغير ما بنيت عليه، من مصلحةٍ، أو عرفٍ، أو زمان، وقد ذكر شيخ الإسلام ابن تيمية 


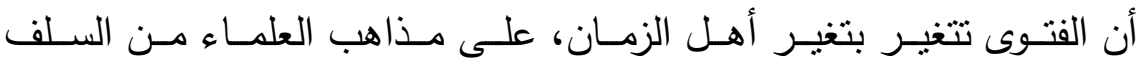
والخلف (') وذكر ابن القيم أن المفتي لا يتمكن من الفتوى والحكم، إلا بنوعين من الفهر: الأول: فهم الواقـع والفقـهـ فيـه، واسـتنباط علـم حقيقـة مـا وقـع بـالقرائن والأمارات حتى يحيط به علماً. الثاني: فهم الواجب في الواقع، وهو فهم حكم الله ثيَّلْ الذي حكم بـه في

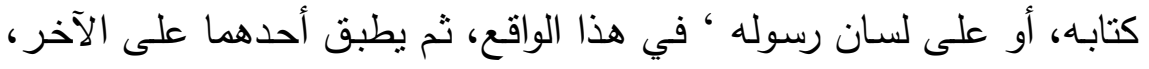
وذكر أن العالم من يتوصل بمعرفة الواقع والتفقه فيه إلى معرفة حكم الله هيَّلن ورسوله ويقول الثـاطبي: " لا يصح للعالم إذا سُئلَّ عن أمرٍ كيف يحصل في

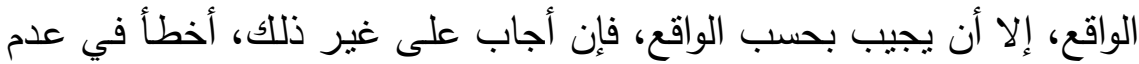

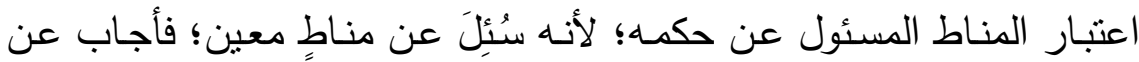

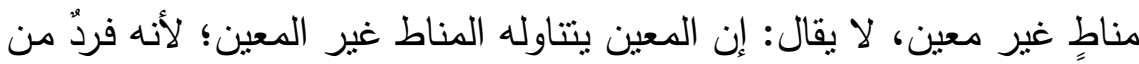

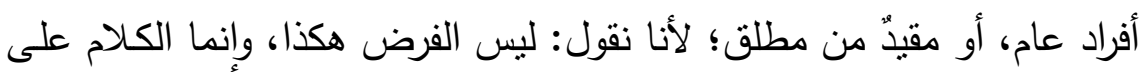

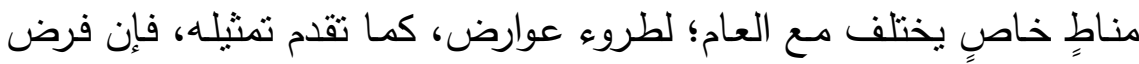
عدم اختلافهما؛ فالجواب إنما يقع بحسب المناط الخاص " (ז). وعلى المفتي اعتبار عوائد الناس ومراعاتها؛ لاختلاف الفتوى باختلاف عرف السائل، ومن ذللك على سبيل التمثيل: صور القبض، والتشبه بالكفار في

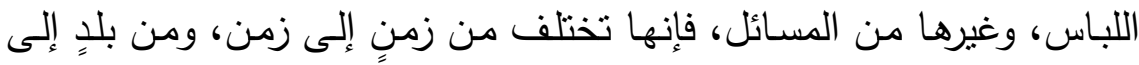
بلد، فما كان يتبع العوائد، فإن حكمه يتغير بتغير العادة إلى ما تقتضيه العادة

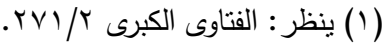

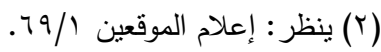

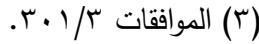


المتجددة ') وذكر القرافي أن الأحكام المترتبة على العوائد تدور معها كيفما

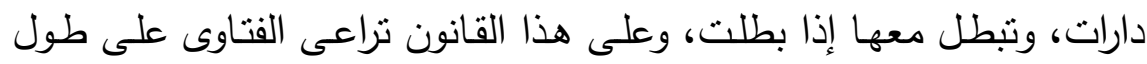

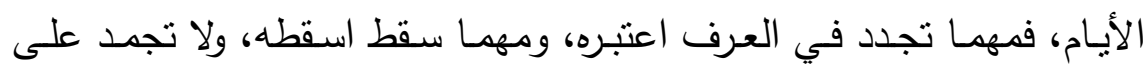

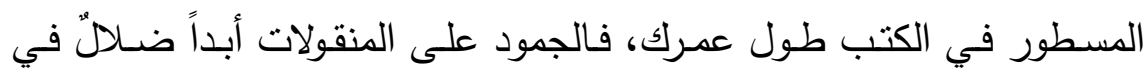

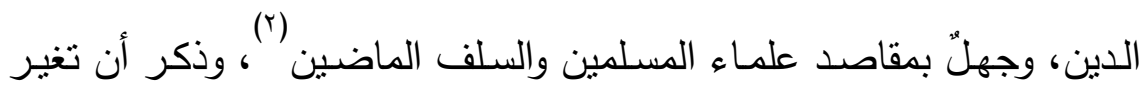
العرف يوجب بطلان الفتوى المبنية عليه؛ لعدم مدركها، فالفتاوى تتبع العوائد

كيفما تقلبت (r)

وقال ابن القيم: " ومـن أفتى النـاس بمجرد المنقول في الكتب على اختلاف عرفهم وعوائدهم، وأزمنتهم، وأمكنتهم، وأحوالهم، وقرائن أحوالهم، فقد الند

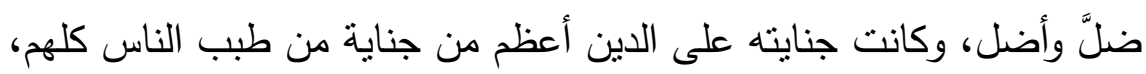

على اختلاف بلادهم، وعوائدهم، وأزمنتهم، وطبائعهم" (2.

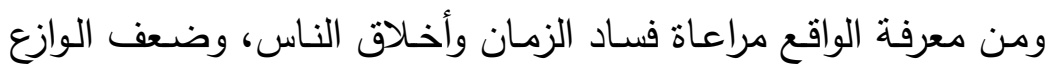

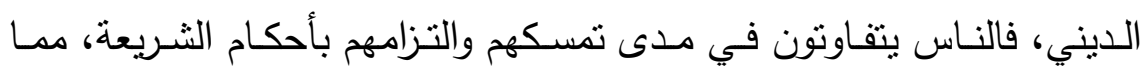

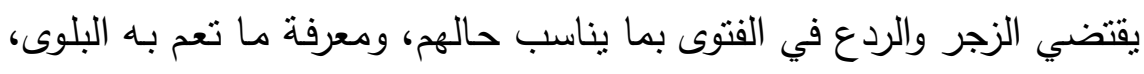
ويكثر وقوعه، بحيث يصعب التخلص منه، ويشق الاحتراز عنه؛ للحاجة إليه،

مما يستدعي التيسير ورفع الحرج ' مان. يقول ابن عابدين: " كثيرٌ من الأحكام تختلف باختلاف الزمان؛ لتغير

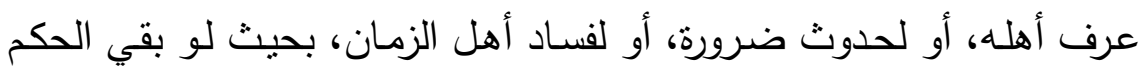

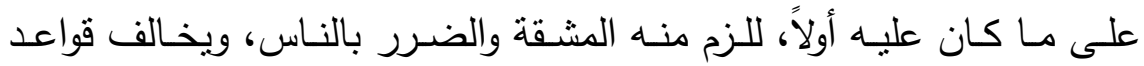

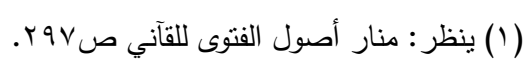

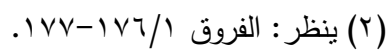

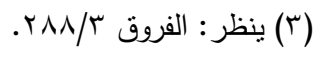

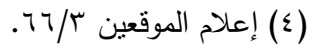

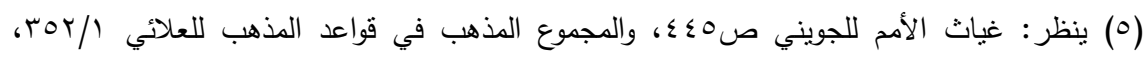

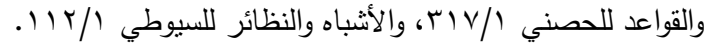


الثـريعة المبنيـة على التخفيف والتيسير ، ودفع الضـرر والفسـاد، ولهذا ترى

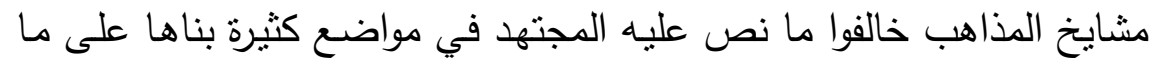

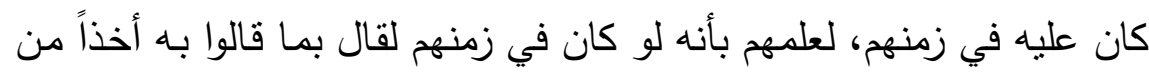

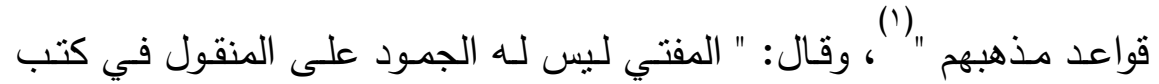

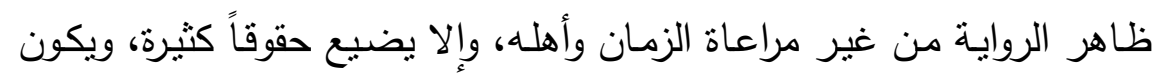

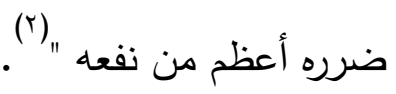

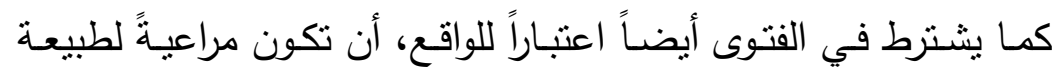

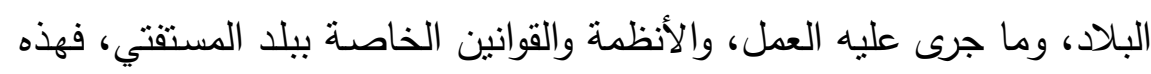

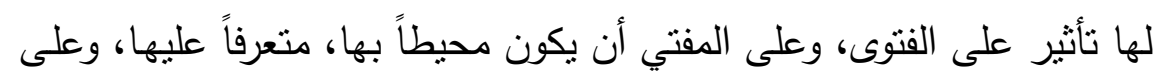

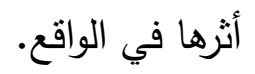
وقد سار على هذا المنهج الصحابة رضي الله عنهم، ومن اقتفى أثرهم

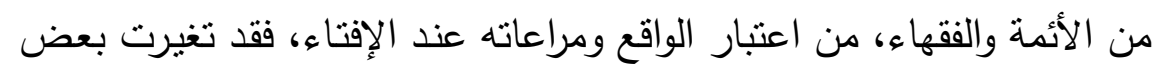

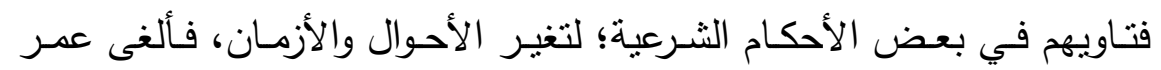
رضي الله عنه سهم المؤلفة قلوبهم (־) لعدم الحاجة إلى ذلك في زمنه، خلافاً

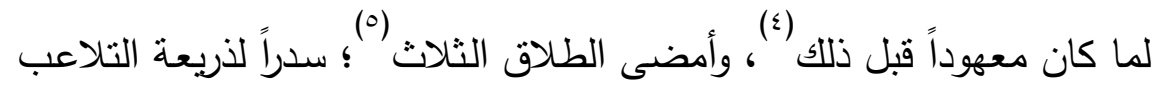

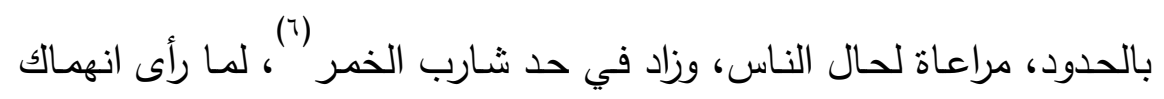

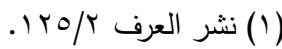

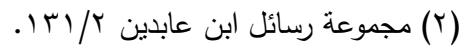
(r) رواه البيهقي في كتاب قسم الصدقات، باب: سقوط سهم المؤلفة قلوبهم وتلاكك إعطائهم عند ظهور

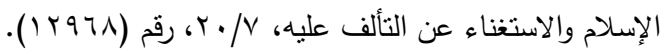

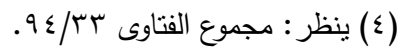

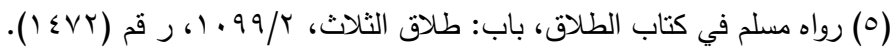

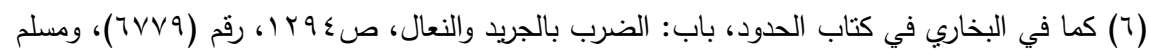

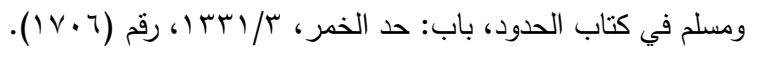


الناس في شربها (') لزجرهم عنها، وفتوى عثمان بن عفان رضي الله عنه في

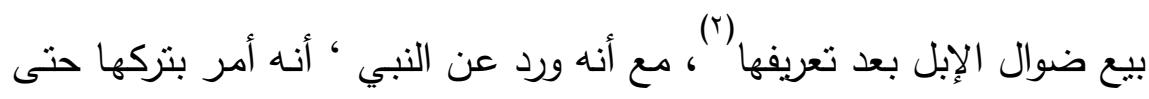
يجئ صاحبها (") وذلك حفظاً لأموال الناس؛ لفساد الزمان، وتغير حال الناس.

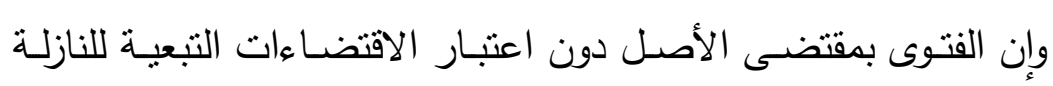

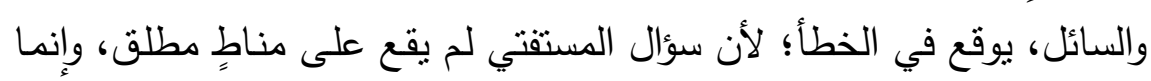

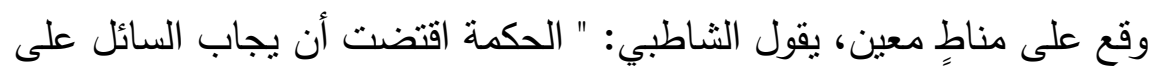

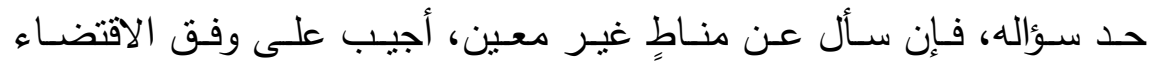

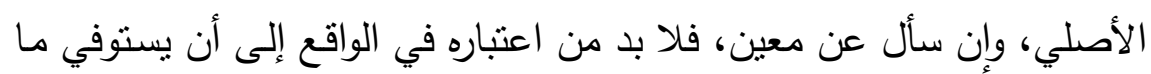

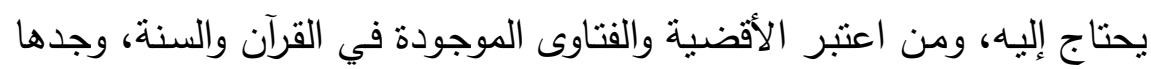

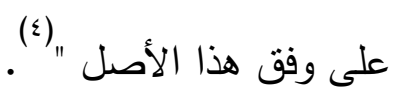

فعدم معرفة الواقع يفضي إلى الخلل في الفتوى، وعدم الاحتياط فيها؛ مراعاةً لفساد الزمان، أو عدم اعتبار مـا يقتضي التيسبر والتخفيف؛ مراعـاة لعموم البلوى وحاجات الناس.

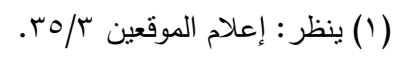

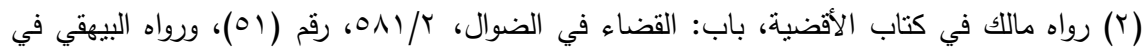

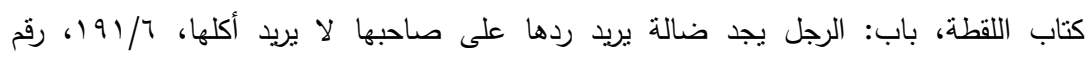

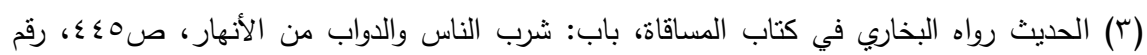

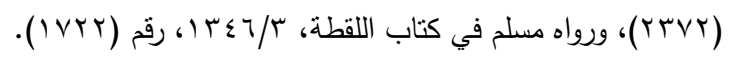

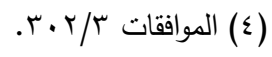




\section{المبحث السادس:}

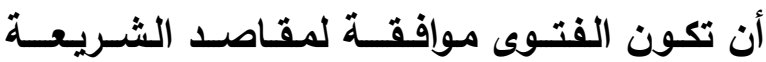

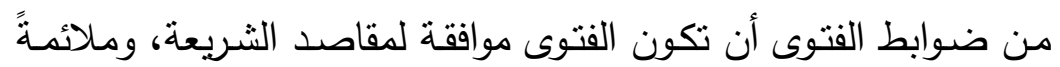

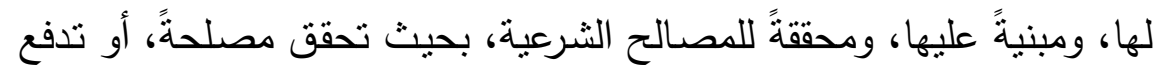

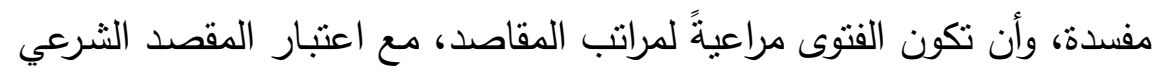

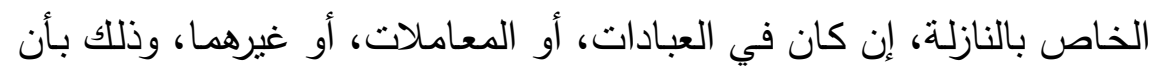

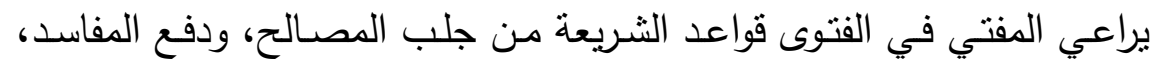

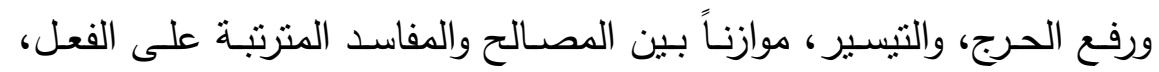

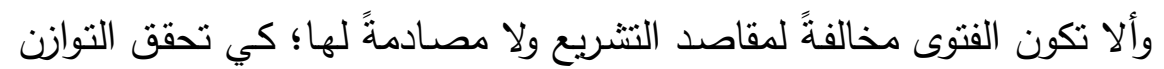

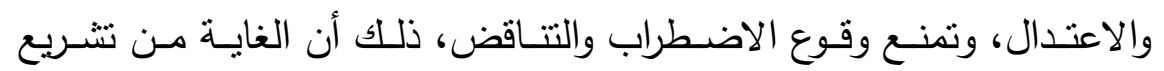

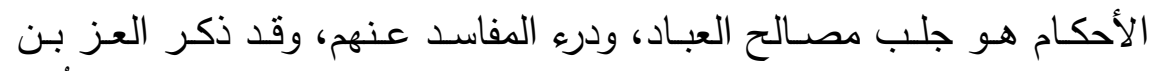

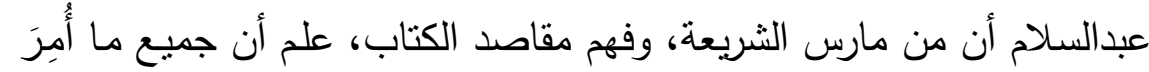

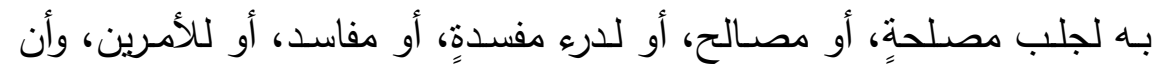

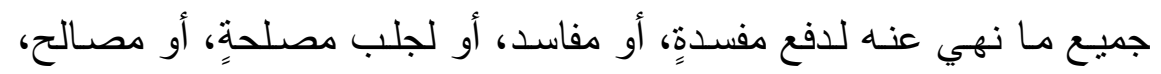
أو للأمرين معاً '(1)

فيلزم المفتي أن يتحرى قصد الثارع نظراً، وواقعاً، وألا يقف عند مجرد

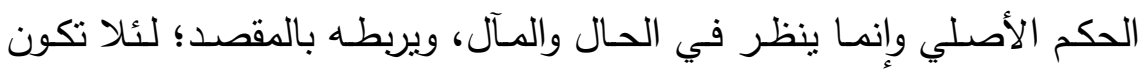

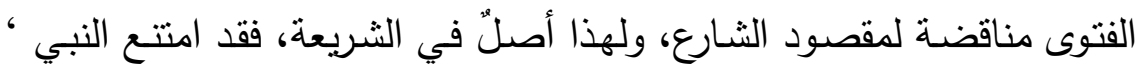

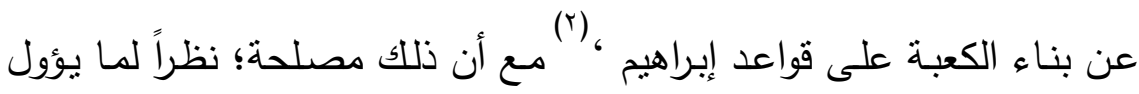

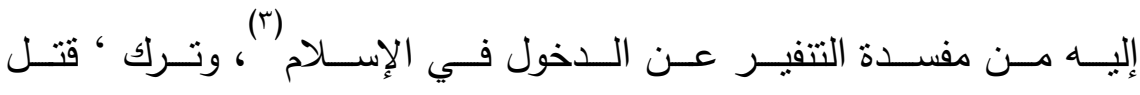


المنـافقين (') مـع كونـه مصلحة؛ لمـا يفضـي إليهـ ذلك من تتفير النـاس عن الدخول في الإسلام (T)

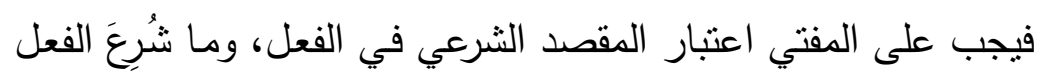

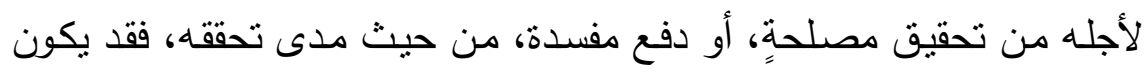

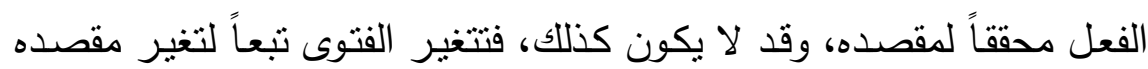

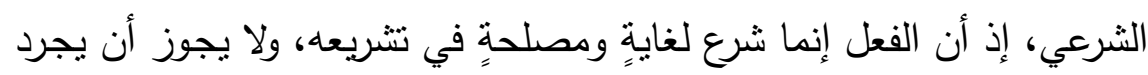

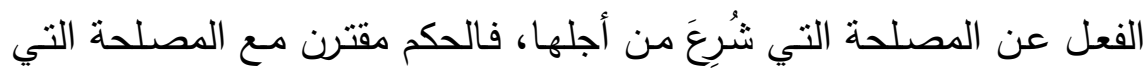

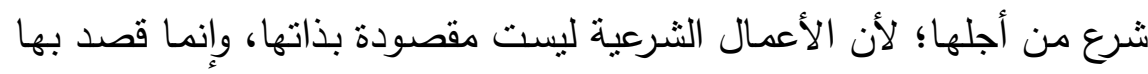
أمور أخر هي معانيها، وهي المصالح التي شرعت من أجلها (r).

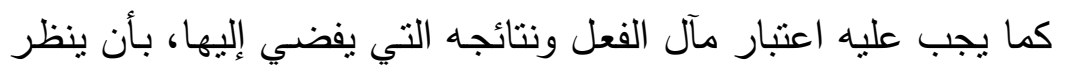

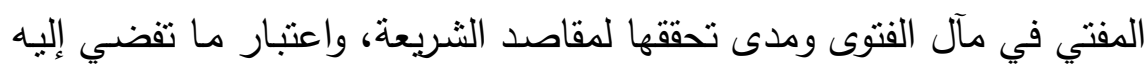
الفتوى؛ حتى تقع موافقة لمقاصد الشرع، فقد تكون وسيلة إلى محرمٍ، فتمنع سداً

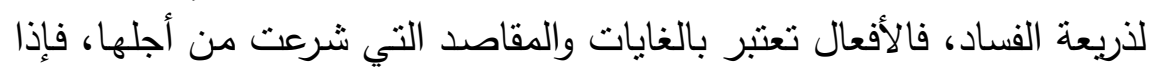

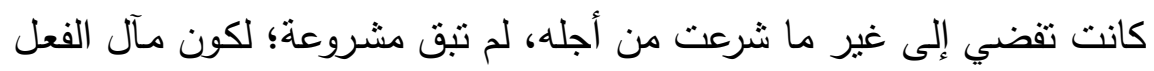

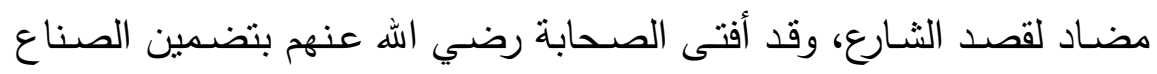

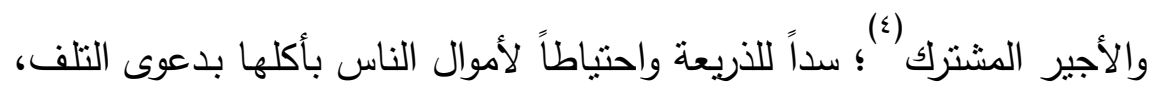

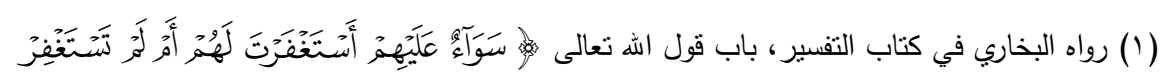

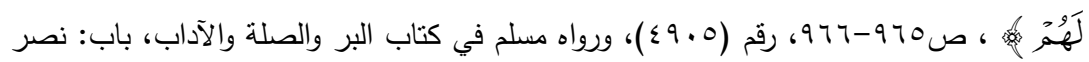

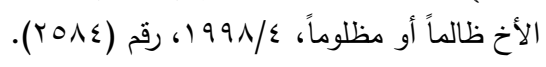

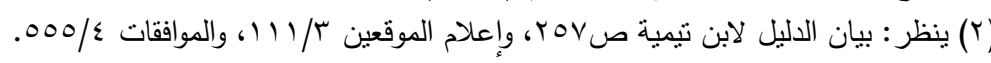

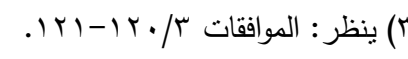

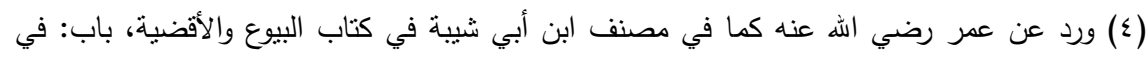

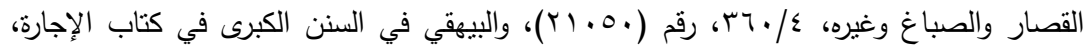

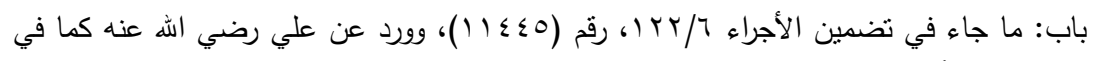

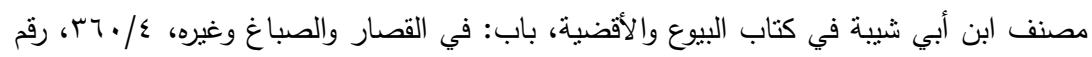


لاسيما عند غلبة الفساد وضعف الوازع الديني (')، وقد يكون الفعل مشروعاً

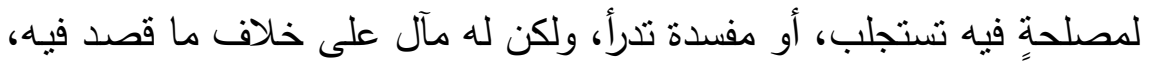

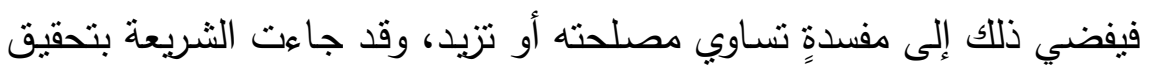

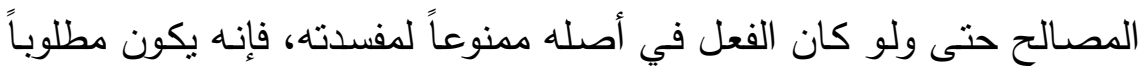

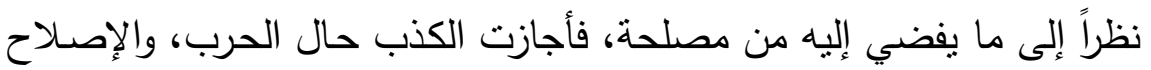

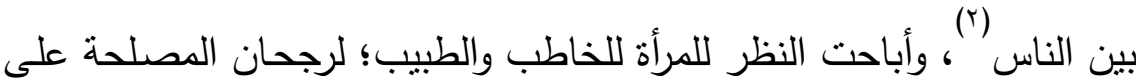
- المفسدة

يقول الثاطبي: " أن المجته لا يحكم على فعلٍ من الأفعال الصادرة

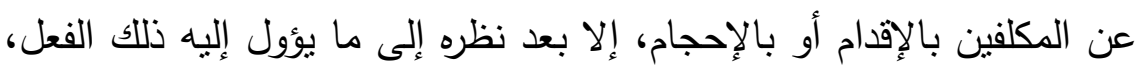

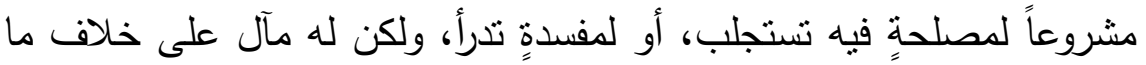

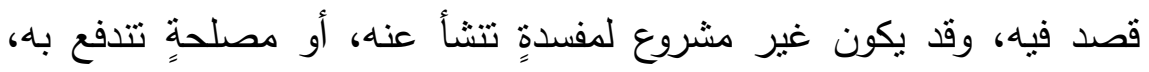

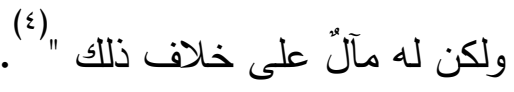
وقد جعل الثـاطبي من خصـائص المجتهد الرباني والراستخ في العلم

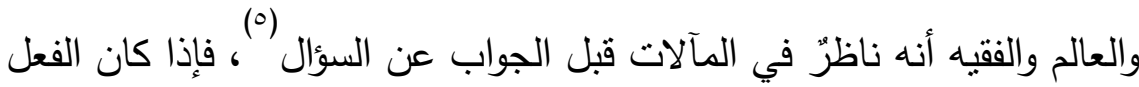

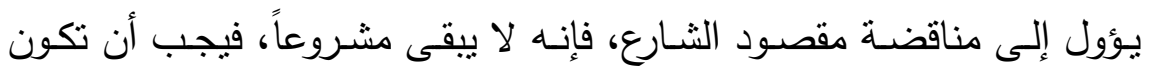
الفتوى بجواز الفعل، أو منعه، بحسب المصلحة، أو المفسدة، التي يؤول إليها،

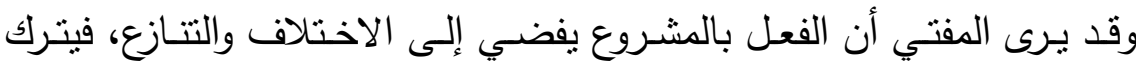

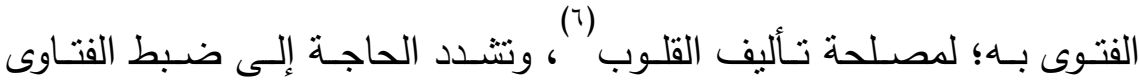

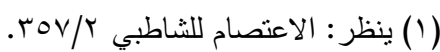

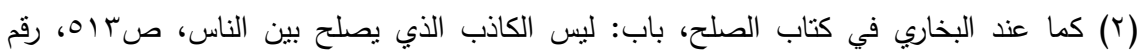

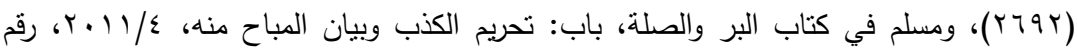

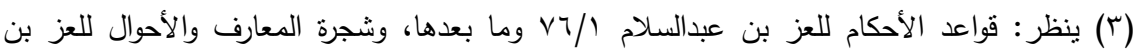

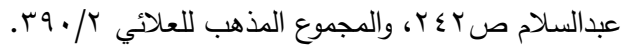

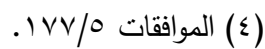

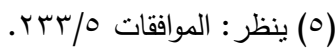

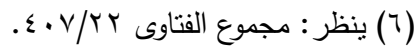




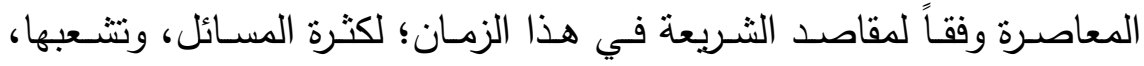
وتداخلها، وتعقدها، وتطورها السريع، وكثرة وقوع التحايل، مما يستدعي النظر

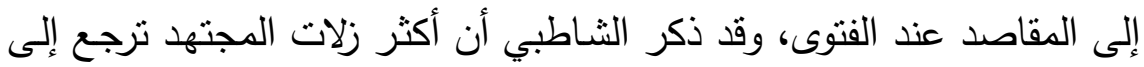

الغفلة عن اعتبار المقاصد '('). 


\section{الخـاتمـــة}

الحمد لله وحده، والصـلاة والسـلام على من لا نبي بعده، وبعد، فقي

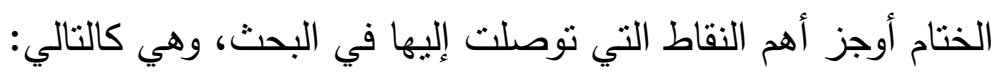

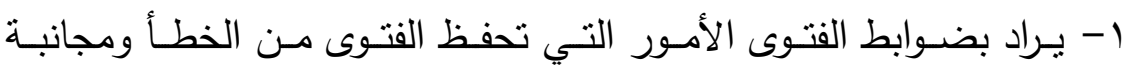
الصواب، إذ إن الإخلال بشيءٍ من هذه الضوابط يفضي إلى عدم صحة الفتوى، ومناقضتها لمقاصد الثربعة.

r- من ضوابط الفتوى أن تصدر الفتوى من مفتٍ مؤهلٍ للفتوى، ومن لم يكن

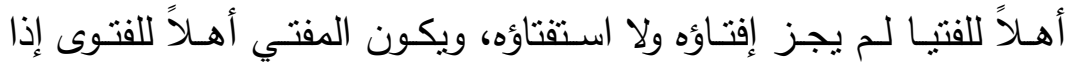

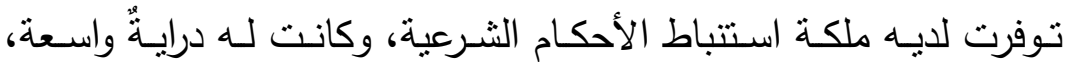
وتأصيلٌ علمي، ومعرفةٌ بالقواعد الأصولية، والمقاصد الشرعية، والتمكن

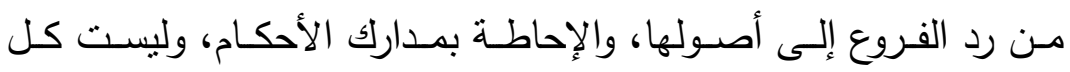

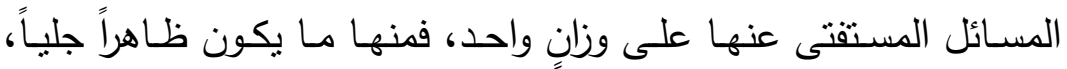

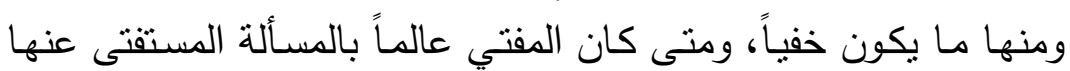
بدليها، جاز له الفتيا فيها. r- من ضوابط الفتيا أن يتصور المفتي المسألة المستفتى عنها تصوراً ناماً

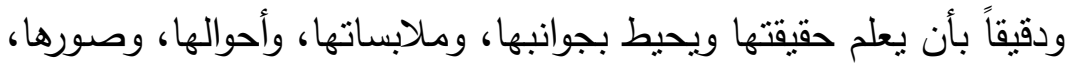
وأن يفهم مراد المسألة بحسب مقصود المستفتي ومراده، وأن يكون مدركاً

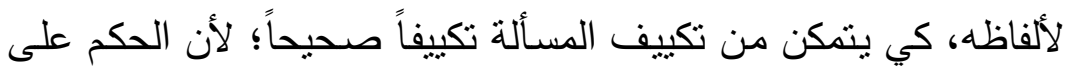

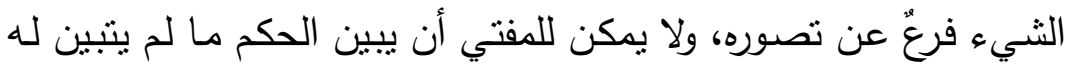

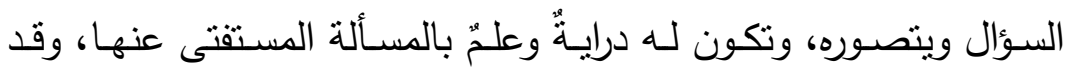

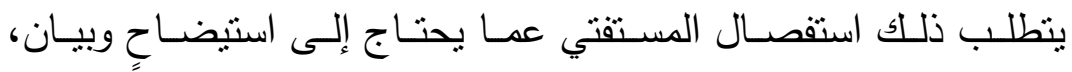
أو الرجوع إلى أهل الاختصاص والخبرة، أو إلى معرفة الأنظمة واللوائح

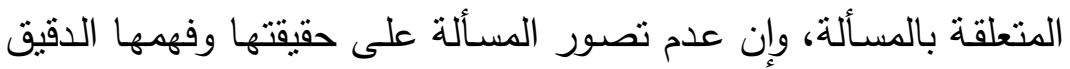
يفضي إلى خطأ الفتوى، وعدم صحة تتزيلها على الواقعة المسؤول عنها. ع - من ضوابط الفتوى أن تبنى الفتوى على أصلٍ شرعي معتبر ، من كتابٍ،

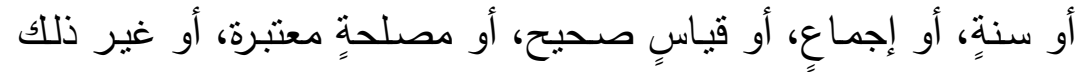


مـن الأدلـة الثـرعية، مراعيـاً في ذلك ترتيب الأدلـة الثـرعية، وضـوابط إعمالها واعتبارها، لأن الفتوى إن لم تكن مبنيةً على دليلٍ، كاعت الته مبنيةً على الهوى، وقد أجمع العلماء على عدم جواز الفتوى بلا دليل.

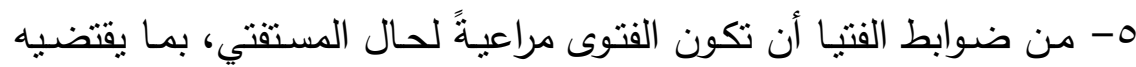

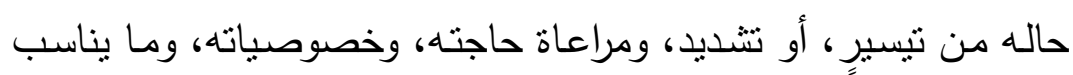

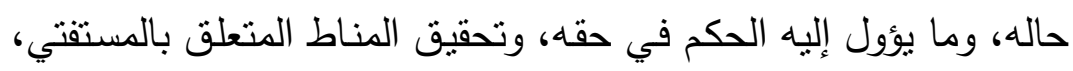
فالنازلة الواحدة يختلف حكمها بحسب حال المستقتي، كما ينظر أيضاً في قصد المستفتي، ومدى موافقته لمقصود الثـارع؛ لئلا يتخذ الفتوى ذريعةً في التحايل على الأحكام الثـرعية، ويتطلب ذللك من المفتي أن يكون

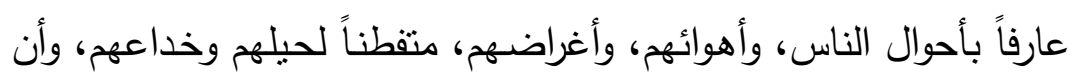

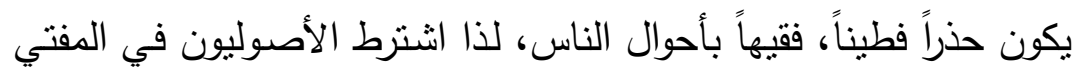
معرفة الناس. צ- مـن ضــوابط الفتبـا أن تكـون الفتوى مراعيـةً للواقـع، والظـروف المكانيـة

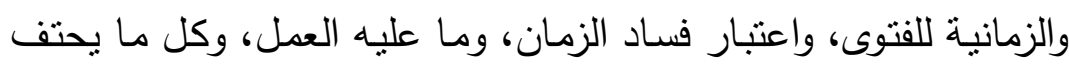

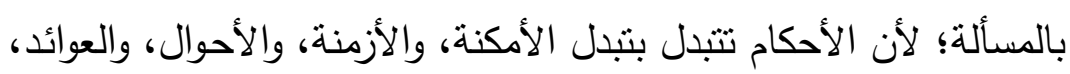

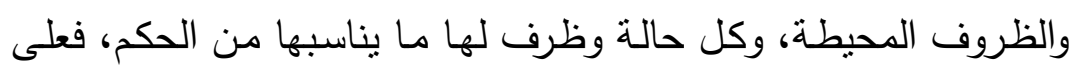

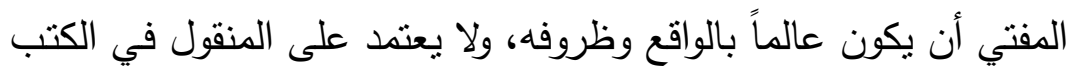

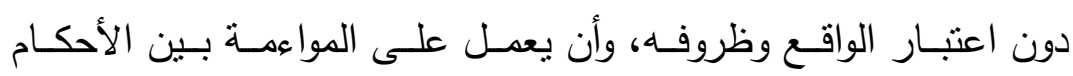
الثرعية وتطبيقها على الواقع.

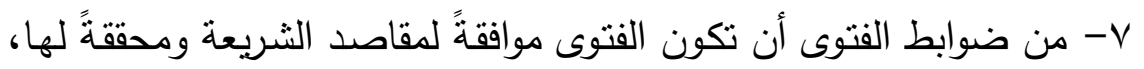

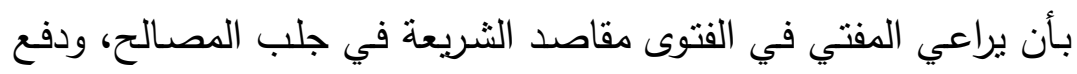

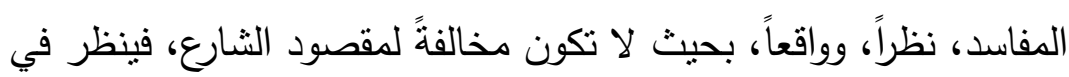

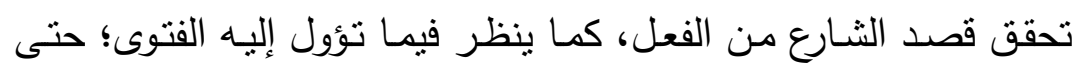
لا تفضي إلى مناقضة مقصود الثارع. والله تعالى أعلم، وصلى الله وسلم على نبينا محمدٍ، وعلى آله وصحبه لهُه وسلم. 


\section{فهرس المصادر والمراجع}

1-الإبهاج في شـرح المنهاج: لعلي السبكي (ت لـهـهـ)، وابنـه عبدالوهاب

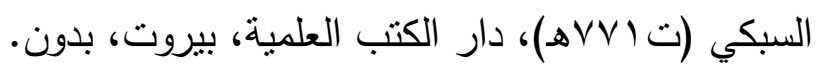

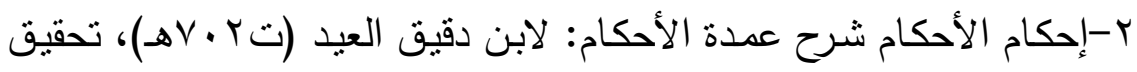

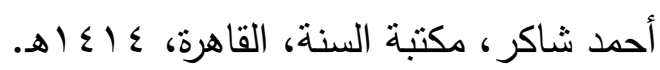

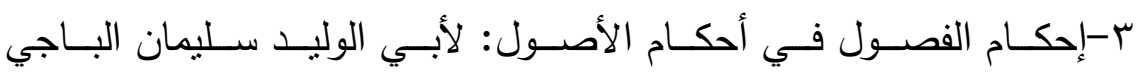

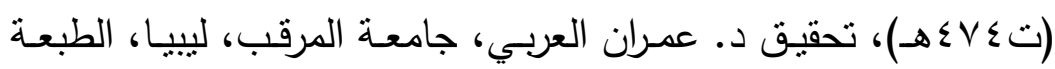

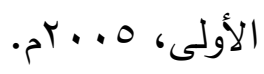

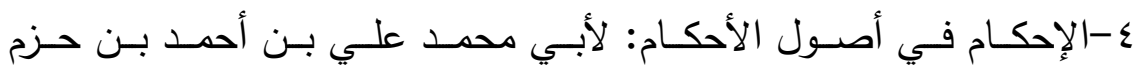

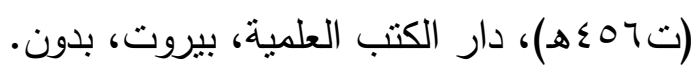

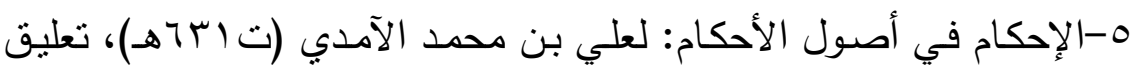

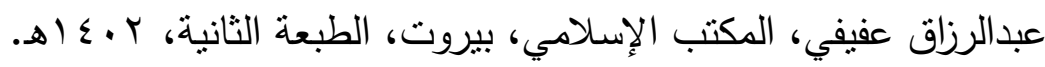

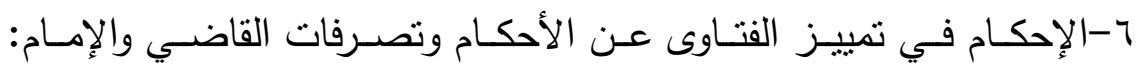

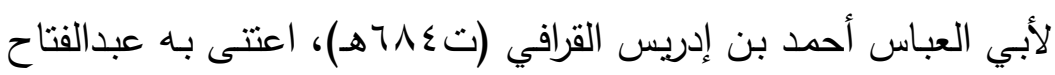

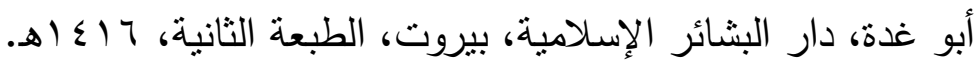

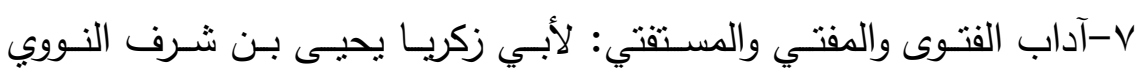

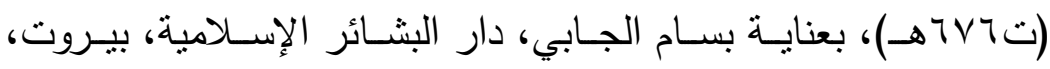

\section{الطبعة الثانية، الهـأهـ}

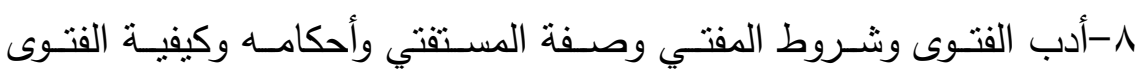

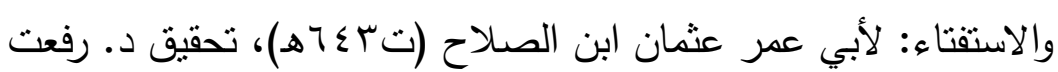

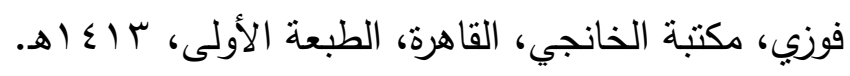

9-إرواء الغليل في تخريج أحاديث منار السبيل: لمحمد ناصر الدين الألباني

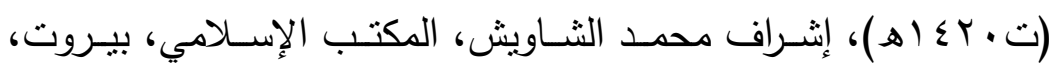

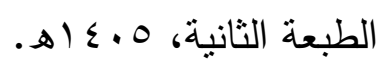

• 1-الأثباه والنظائر في قواعد وفروع فقه الثافعية: لجلال الدين عبدالرحمن السيوطي (ت الو9ه)، تحقيق علاء السيد، نشر مكتبة دار الباز ، بدون. 


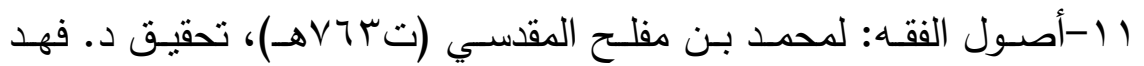

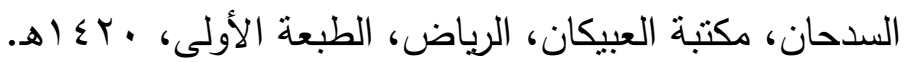

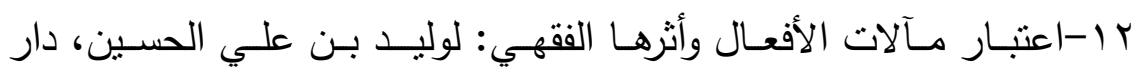

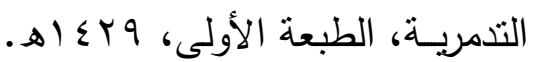

سا -الاعتصام للشاطبي تحقيق: الثقير وآل حميد والصيني، دار ابن الجوزي،

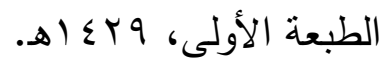

ع ا-إعلام الموقعين إعلام الموقعين عن رب العالمين: لأبي عبداله محمد بن

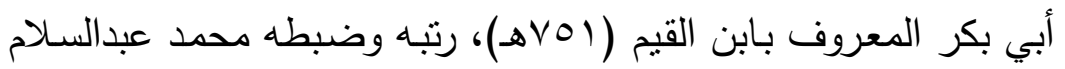

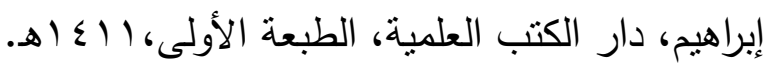

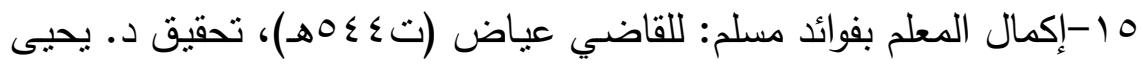

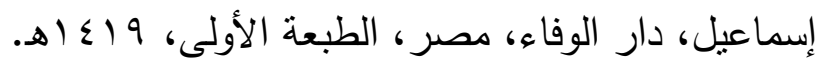

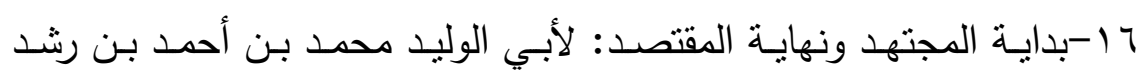

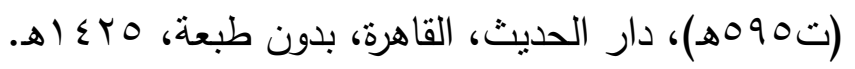
IV

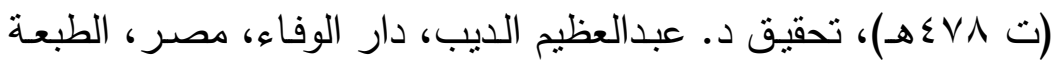

\section{الثالثة، rإ إهـ}

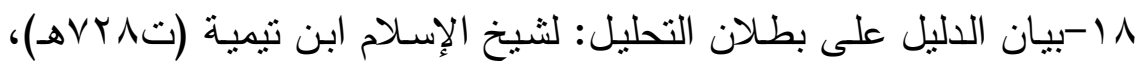

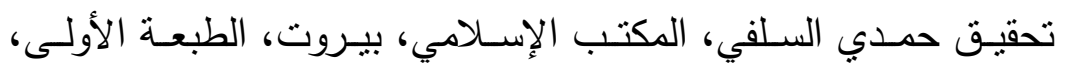

$$
\text { . ه }
$$

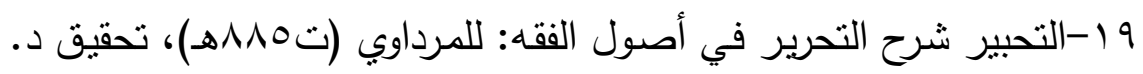

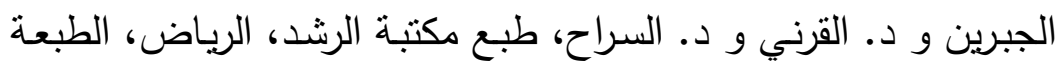

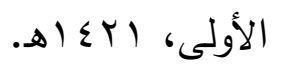

• r-التلخيص الحبير في تخريج أحاديث الرافعي الكبير : لأحمد بـن علي

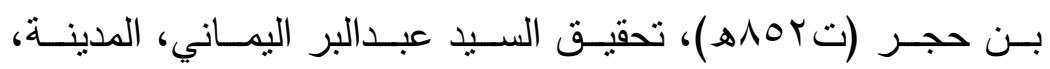




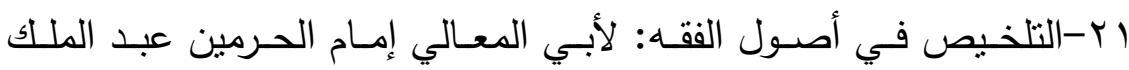

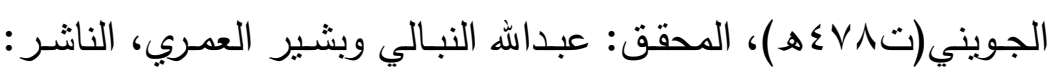

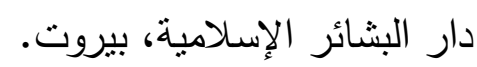

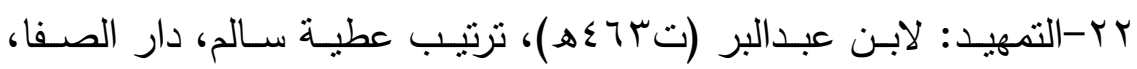

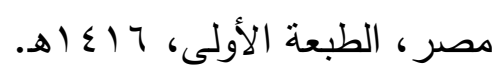

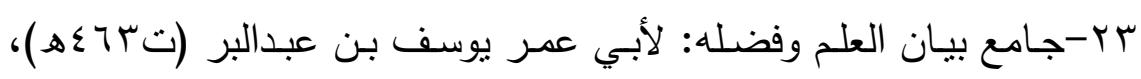

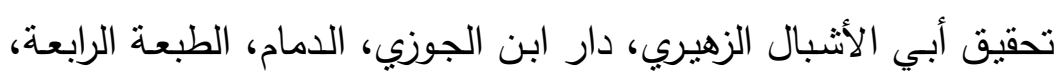

(اله 19

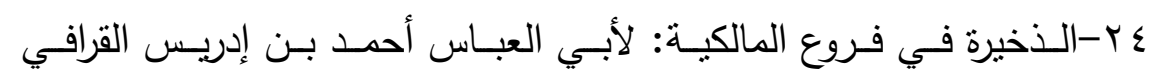

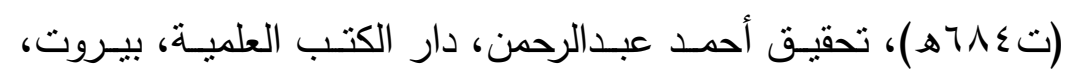

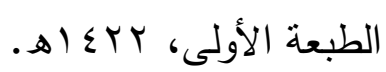

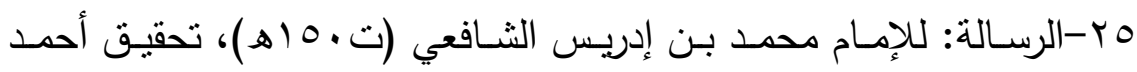

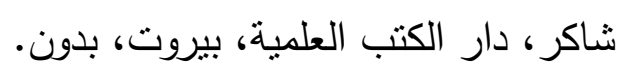

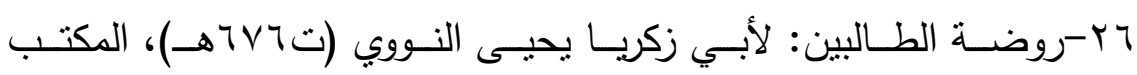

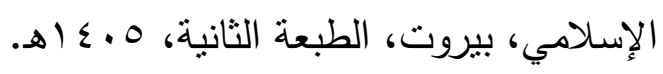

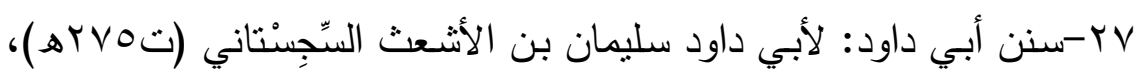

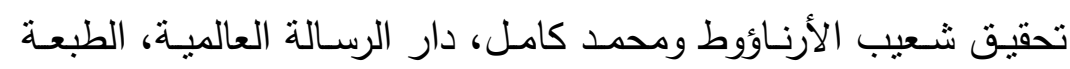

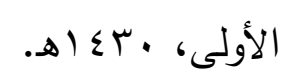

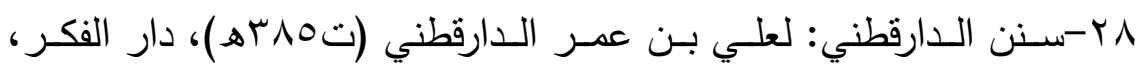

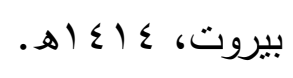

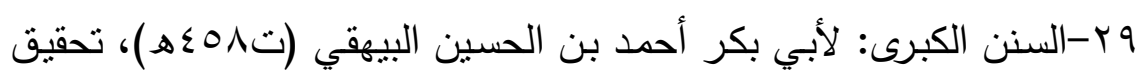

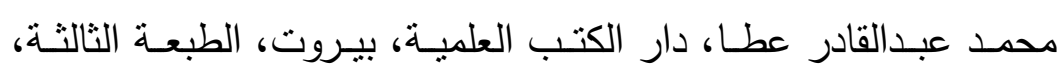

\section{. $) \leqslant Y \leqslant$}

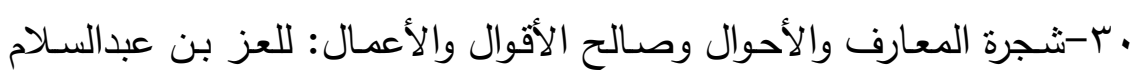
(ت. • 17هـ)، اعتنى به حسان عبد المنان، بيت الأفكار الدولية، الأردن. 


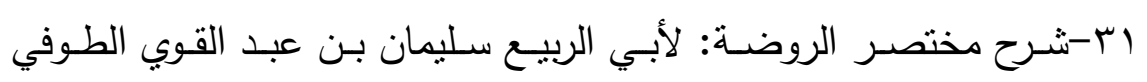

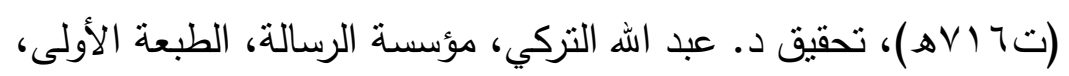

$$
\text { ه } 8 . V
$$

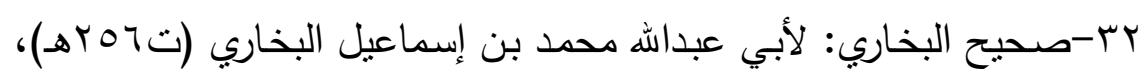

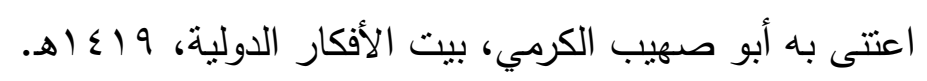

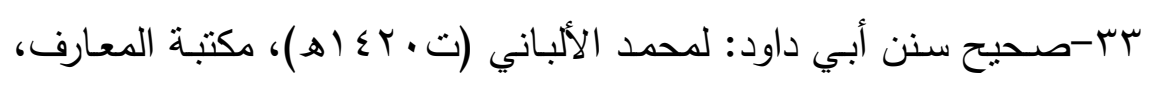

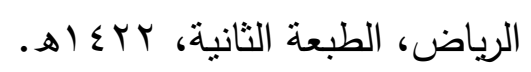

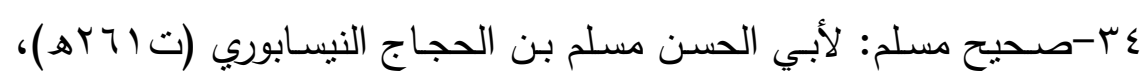

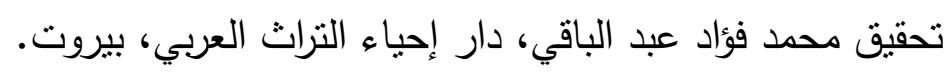

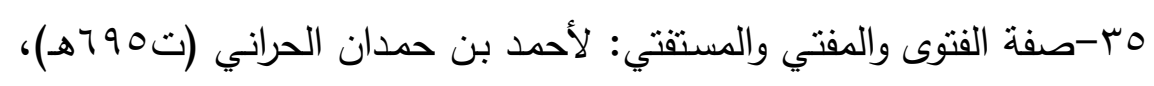

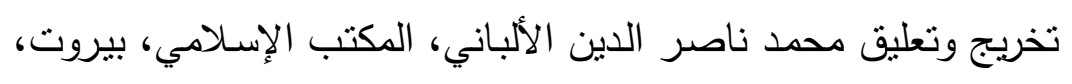

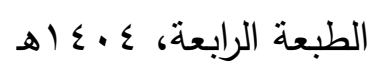

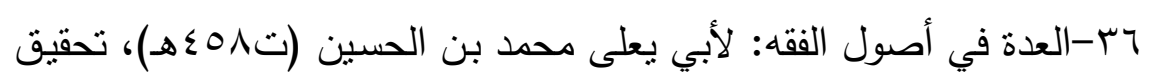

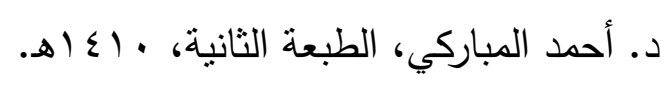

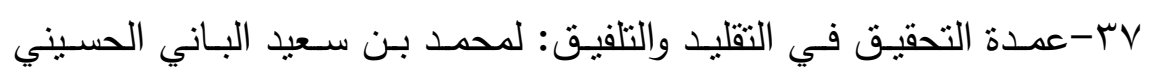

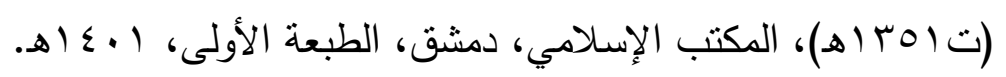

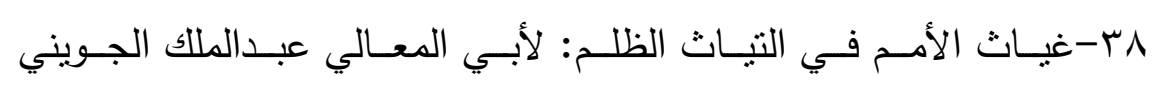

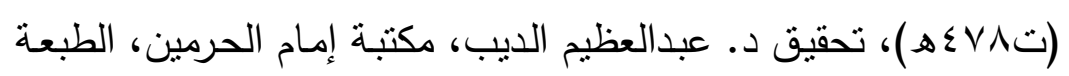

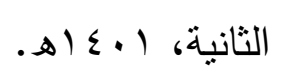

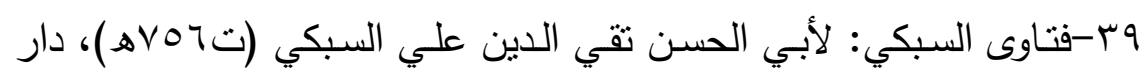

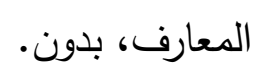

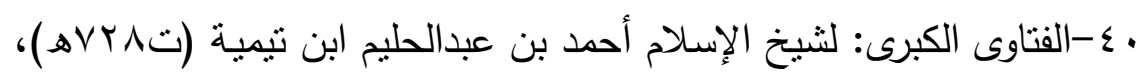

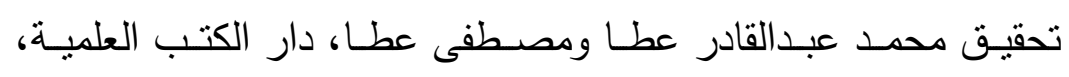

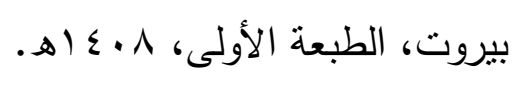




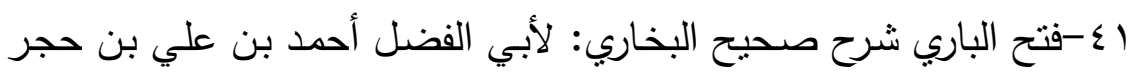

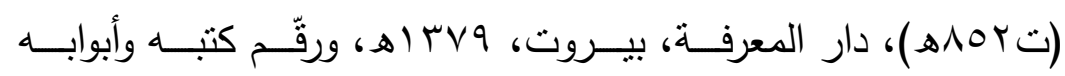

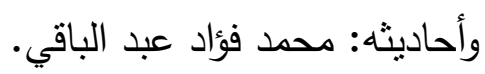

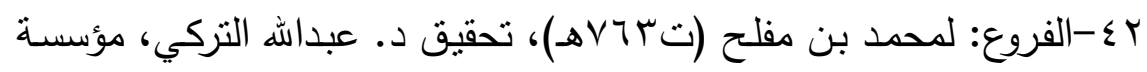

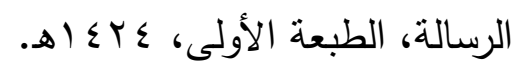

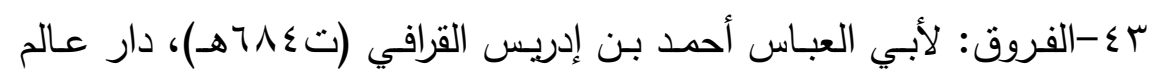

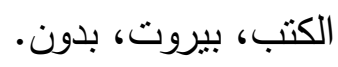

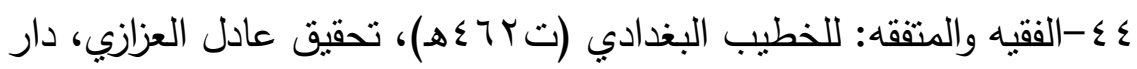

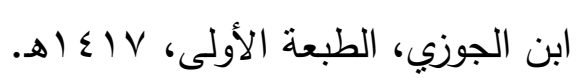

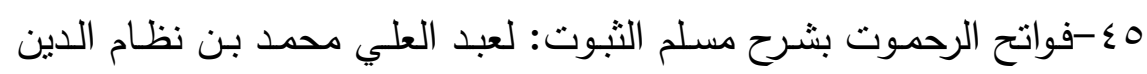

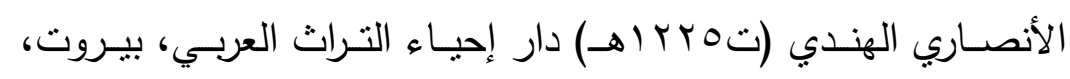

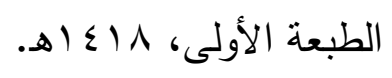

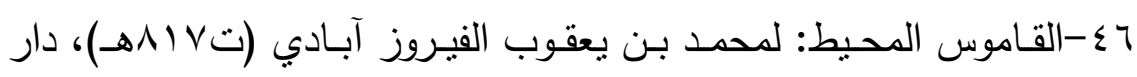

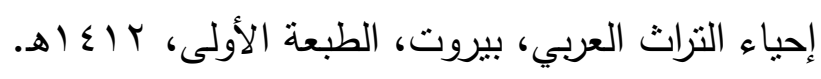

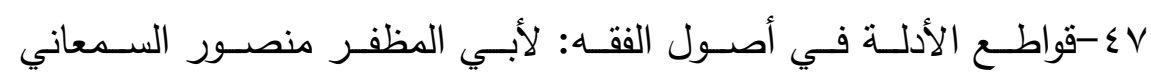

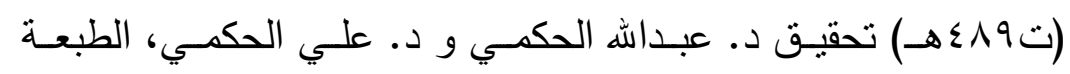

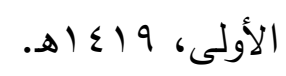

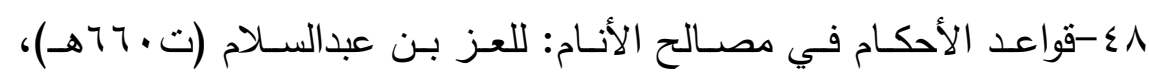

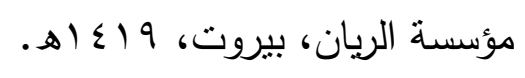

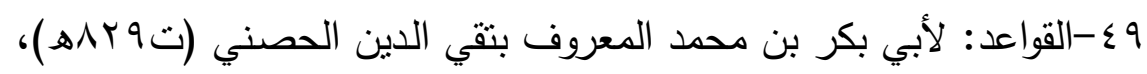

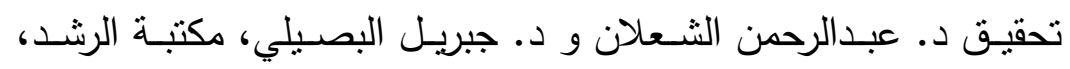

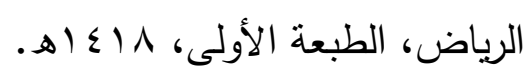

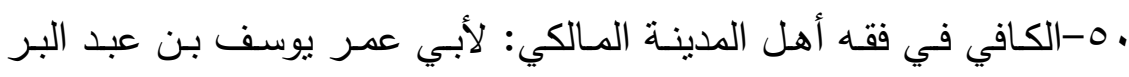

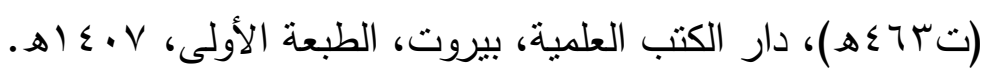


10-كثف الأسـرار عن أصسول فخر الإسـام البزدوي: لعبدالعزيز بن أحمد

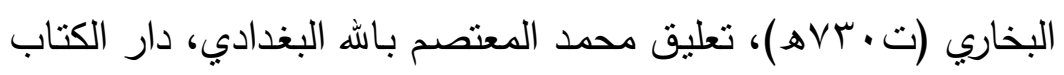

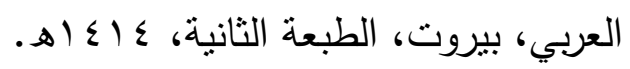

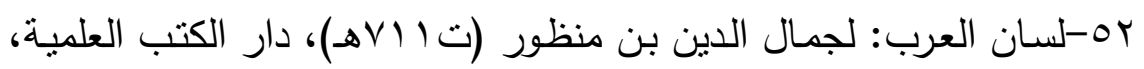

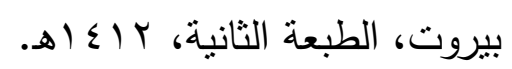

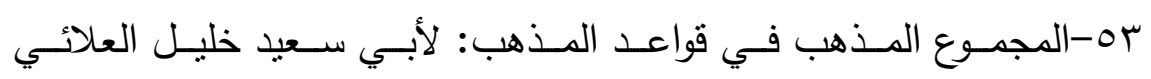

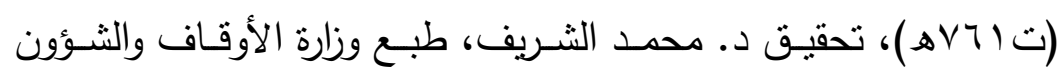

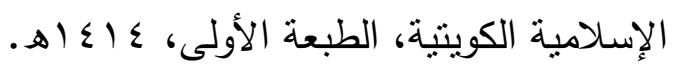

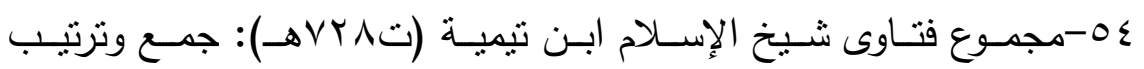

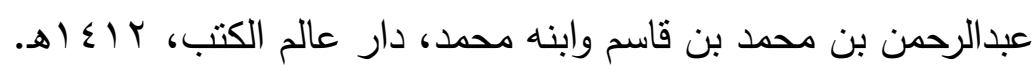

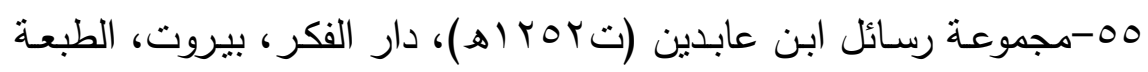

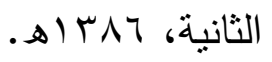

7ه-المحصـول في علم أصـول الفقه: لفخر الدين محمد بـن عمر الرازي

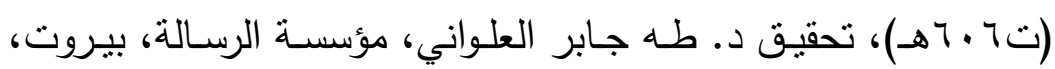

\section{الطبعة الثالثة، 1 إك الهـ.}

VV-OVختصـر الفوائد في أحكام المقاصد ( القواعد الصـغرى ): لعز الدين

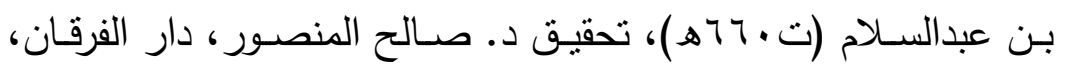

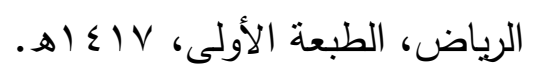

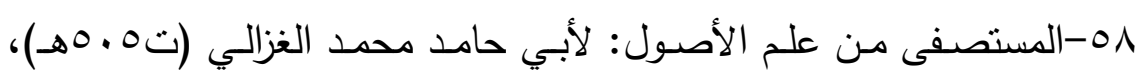
تحقيق د. حمزة حافظ، بدون.

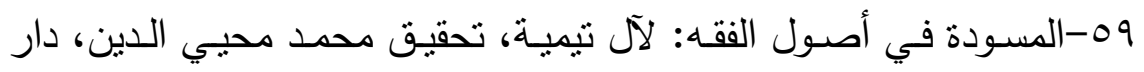
الكتاب العربي، بيروت، بدون. • צ-مصـنف ابـن أبسي شـيبة " الكتـاب المصـنف في في الأحاديـث والآثار":

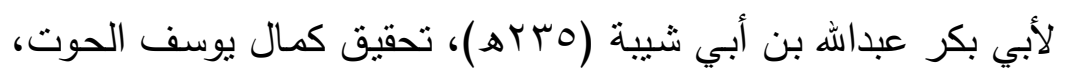

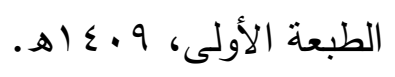




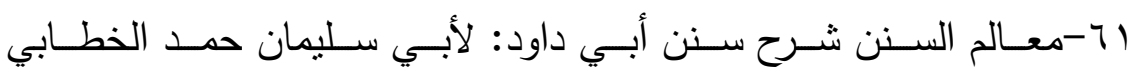

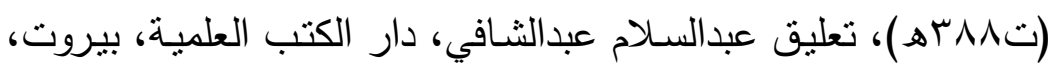

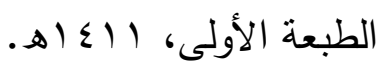

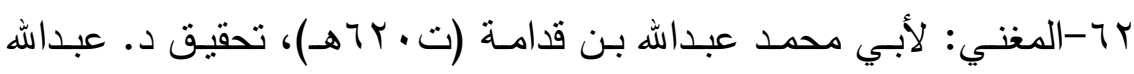

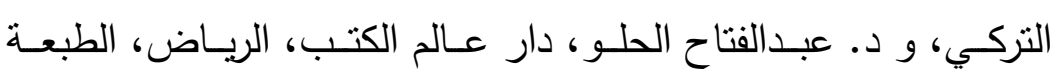

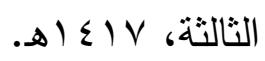

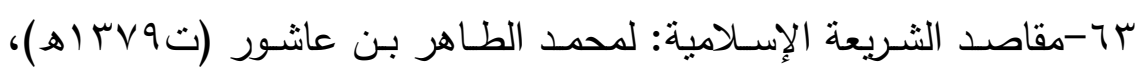

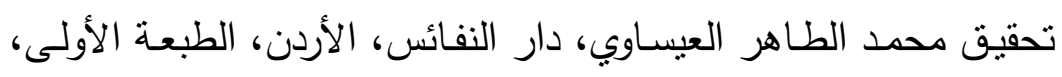
. $1 \leqslant Y$.

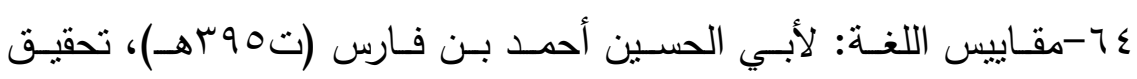

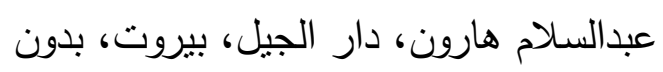

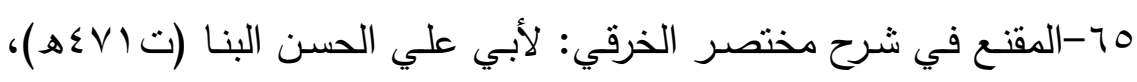

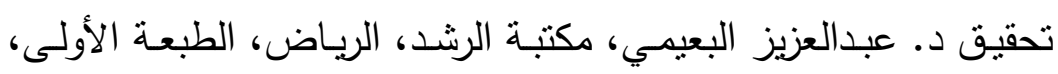
. $1 \leqslant 1 \leqslant$

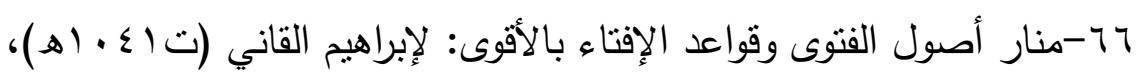

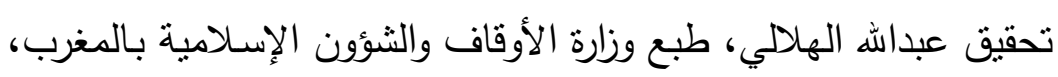
.

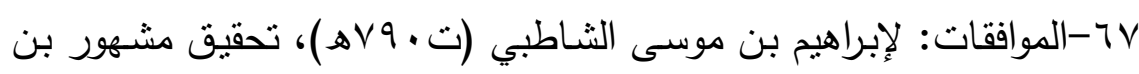

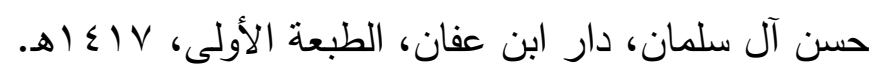

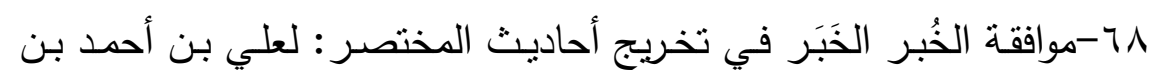

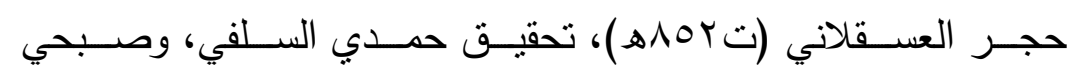

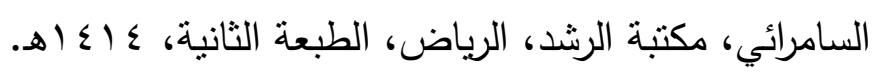

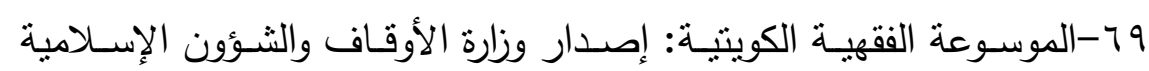

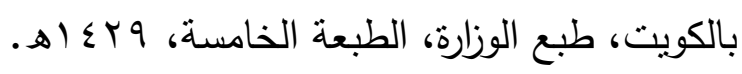


•Vموطأ الإمـام مالك: للإمـام مالك بن أنس (V9 ( هـ)، تحقيـق د. بشـار

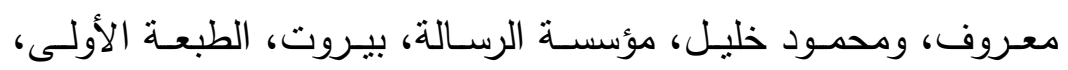

$$
\text { r آهات }
$$

|V-نشر العرف في بناء بعض الأحكام على العرف: لمحمد أمين بن عابدين

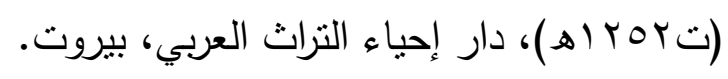



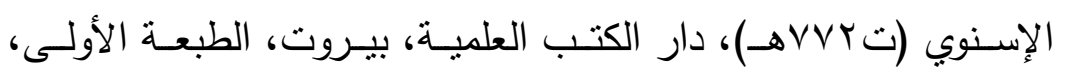

$$
\text { . }
$$

r-VT-نهاية الوصول إلى علم الأصول: لأحمد بن علي بن تغلب بن الساعاتي

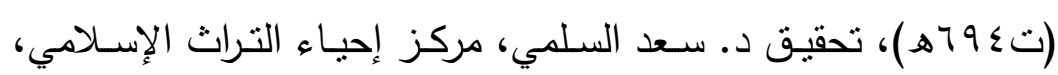

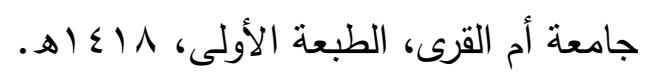

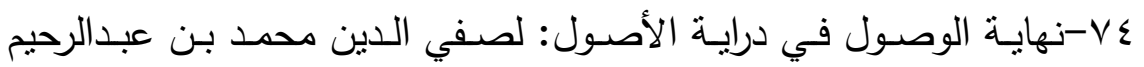

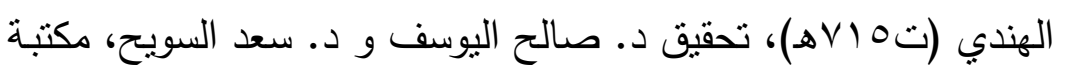

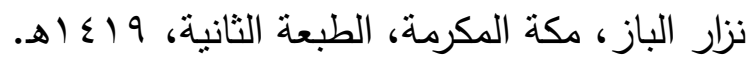

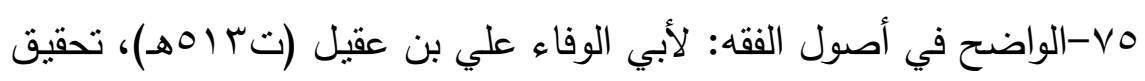

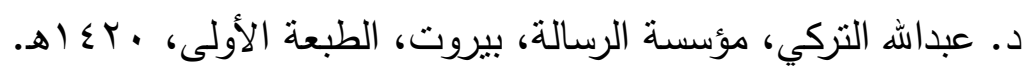


مجلة كلية الدراسات الإسلامية والعربية للبنات بدمنهور العدد السادس الإصدار الثاني الجزء الأول اب.rم

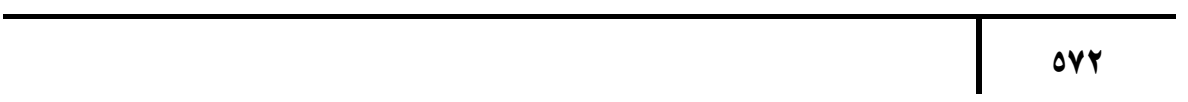

